Composition by Marcia Jones, Group EES-1

This work was supported by the U.S. Agency for International Development.

\section{An Affirmative Action/Equal Opportunity Employer}

This report was prepared as an account of work sponsored by an agency of the

United States Government. Neither the United States Government nor any agency thereof, nor any of their employees, makes any warranty, express or implied, or assumes any legal liability or responsibility for the accuracy, completeness, or usefulness of any information, apparatus, product, or process disclosed, or represents that its use would not infringe privately owned rights. Reference herein to any specific commercial product, process, or service by trade name, trademark, manufacturer, or otherwise, does not necessarily constitute or imply its endorsement, recommendation, or favoring by the United States Government or any agency thereof. The views and opinions of authors expressed herein do not necessarily state or reflect those of the United States Government or any agency thereof. 


\section{DISCLAIMER}

This report was prepared as an account of work sponsored by an agency of the United States Government. Neither the United States Government nor any agency Thereof, nor any of their employees, makes any warranty, express or implied, or assumes any legal liability or responsibility for the accuracy, completeness, or usefulness of any information, apparatus, product, or process disclosed, or represents that its use would not infringe privately owned rights. Reference herein to any specific commercial product, process, or service by trade name, trademark, manufacturer, or otherwise does not necessarily constitute or imply its endorsement, recommendation, or favoring by the United States Government or any agency thereof. The views and opinions of authors expressed herein do not necessarily state or reflect those of the United States Government or any agency thereof. 


\section{DISCLAIMER}

Portions of this document may be illegible in electronic image products. Images are produced from the best available original document. 
Results of Investigations at the

Ahuachapán Geothermal Field, El Salvador

Part 1: Well Logging and Brine Geochemistry

Compiled by

Bert Dennis

Fraser Goff

Ed Van Eeckhout

Bob Hanold

Contributors
A. Adams
$D$. Counce
G. Cuéllar*
C. Escobar*
C. Grigsby
C. Janik**
$R$. Jermance
J. Kolar
R. Lawtont
M. Maltez*
P. Trujillo, Jr.

* La Comisión Ejecutiva Hidroeléctrica del Río Lempa,

Apartado Postal 2669, Código Postal 01118, San Salvador, EL SALVADOR. **US Geological Survey, Menlo Park, CA 94025.

tConsultant at Los Alamos. P.O. Box 310RL, Santa Fe, NM 87501.

\section{DISTRIBUTION OF THIS DOCUMENT IS UNLIMITED}


$$
\text { . }
$$ 


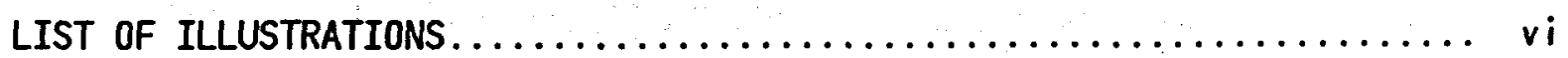

LIST OF TABLES $\ldots \ldots \ldots \ldots \ldots \ldots \ldots \ldots \ldots \ldots \ldots \ldots \ldots \ldots \ldots \ldots \ldots \ldots \ldots \ldots$

EXECUTIVE SUMMARY ............................. ix

RESUMEN EJECUTIVO $\ldots \ldots \ldots \ldots \ldots \ldots \ldots \ldots \ldots \ldots \ldots \ldots \ldots \ldots \ldots \ldots \ldots \ldots$

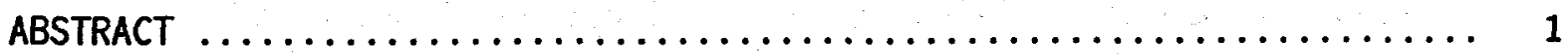

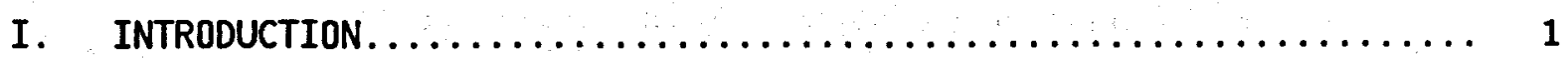

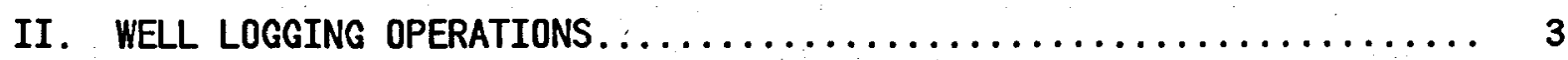

A. Phase I.............................

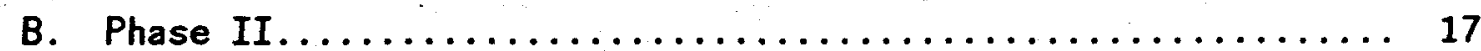

C. Discussion of Equipment-Related Problems............. 31

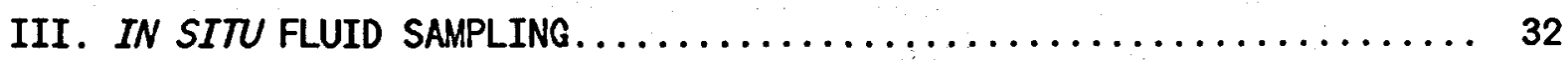

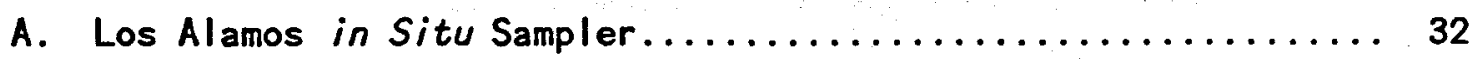

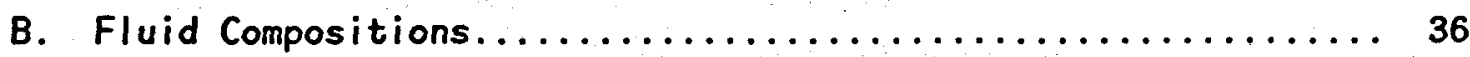

C. Geothermal Well Variations..................... 41

D. Recharge to Ahuachapán System.................... 46

E. Relative Age of Geothermal Waters.................. 50

F. Sources of Carbon......................... 53

G. Chemical Geothermometry................... 53

H. Downhole Fluid Composition of $A H-1$ and $A H-27 \ldots \ldots \ldots \ldots \ldots \ldots$

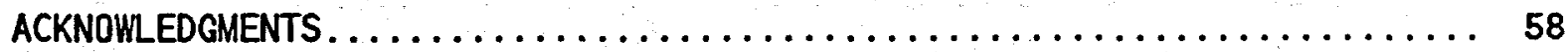

APPENDIX A: GEOTHERMAL WELL LOGGING EQUTPMENT .............. 59

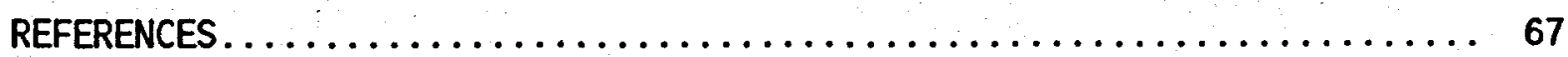




\section{LIST OF ILLUSTRATIONS}

page

Fig. i. Selected temperature logs for well AH-21 (from CEL data)..... x

Fig. ii. Schematic south to north-northeast cross section through Ahuachapán geothermal field showing general configuration of geothermal system in relation to geothermal wells and hot springs...............................

Fig. 1. Schematic map of El Salvador showing location of Ahuachapán.. : 2

Fig. 2. Map of the Ahuachapán geothermal field showing well

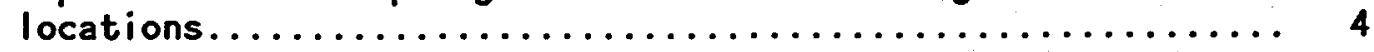

Fig. 3. Temperature/rabbit survey (static), AH-1............ 6

Fig. 4. STP temperature survey $(30 \mathrm{~kg} / \mathrm{s}), A H-1 \ldots \ldots \ldots \ldots \ldots \ldots \ldots$

Fig. 5. Pressure data and saturation pressure $(30 \mathrm{~kg} / \mathrm{s}), A H-1 \ldots \ldots 7$

Fig. 6. STP spinner survey $(30 \mathrm{~kg} / \mathrm{s}), A H-1 \ldots \ldots \ldots \ldots \ldots \ldots \ldots \ldots$

Fig. 7. Calculated flow rate $(30 \mathrm{~kg} / \mathrm{s}), A H-1 \ldots \ldots \ldots \ldots \ldots \ldots \ldots \ldots .9$

Fig. 8. Vapor quality $(30 \mathrm{~kg} / \mathrm{s}), A H-1 \ldots \ldots \ldots \ldots \ldots \ldots \ldots \ldots \ldots . \ldots \ldots$

Fig. 9. Calculated flow rate $(58 \mathrm{~kg} / \mathrm{s}), A H-1 \ldots \ldots \ldots \ldots \ldots \ldots \ldots \ldots$

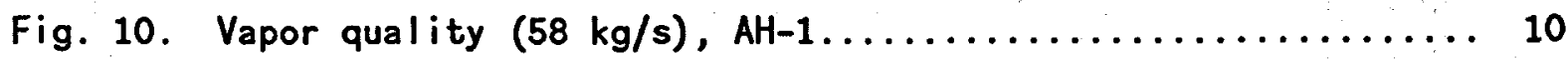

Fig. 11. Temperature/rabbit survey, $A H-27 \ldots \ldots \ldots \ldots \ldots \ldots \ldots \ldots \ldots \ldots \ldots$

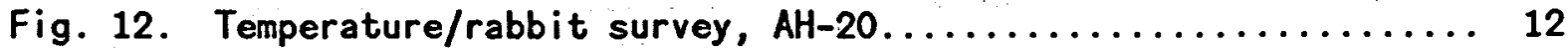

Fig. 13. STP temperature survey, $A H-20 \ldots \ldots \ldots \ldots \ldots \ldots \ldots \ldots \ldots \ldots$

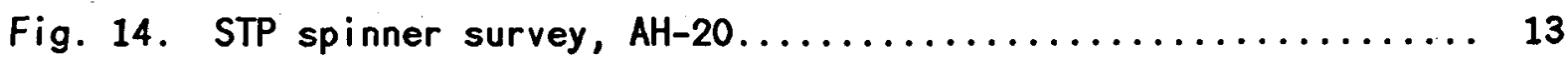

Fig. 15. Three-arm caliper survey, $A H-20 \ldots \ldots \ldots \ldots \ldots \ldots \ldots \ldots \ldots \ldots$

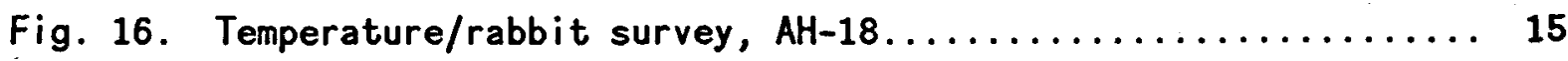

Fig. 17. STP temperature survey, AH-18.................. 16

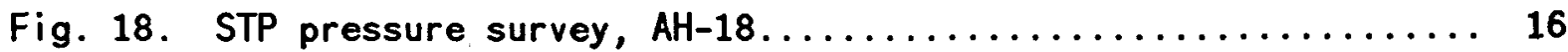

Fig. 19. Three-arm caliper survey, $A H-18 \ldots \ldots \ldots \ldots \ldots \ldots \ldots \ldots \ldots \ldots$

Fig. 20. Three-arm cal iper survey, $A H-32 \ldots \ldots \ldots \ldots \ldots \ldots \ldots \ldots \ldots \ldots$

Fig. 21. STP temperature survey $(20 \mathrm{~kg} / \mathrm{s}), A H-32 \ldots \ldots \ldots \ldots \ldots \ldots$

Fig. 22. Measured and saturation pressures $(20 \mathrm{~kg} / \mathrm{s}), \mathrm{AH}-32 \ldots \ldots 21$

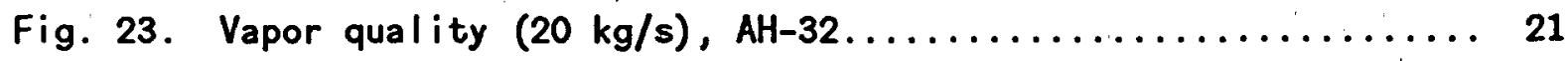

Fig. 24. STP spinner survey $(20 \mathrm{~kg} / \mathrm{s}), A H-32 \ldots \ldots \ldots \ldots \ldots \ldots \ldots \ldots$

Fig. 25. STP temperature survey $(45 \mathrm{~kg} / \mathrm{s}), A H-32 \ldots \ldots \ldots \ldots \ldots \ldots \ldots 23$

Fig. 26. Measured and saturation pressures $(45 \mathrm{~kg} / \mathrm{s}), \mathrm{AH}-32 \ldots \ldots \ldots 24$

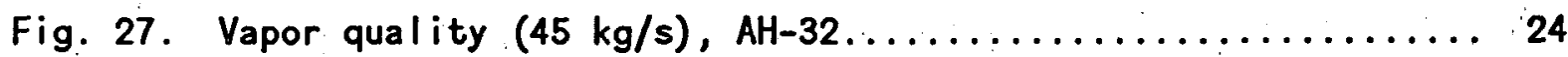


Fig. 28. STP spinner survey $(45 \mathrm{~kg} / \mathrm{s}), A H-32 \ldots \ldots \ldots \ldots \ldots \ldots \ldots$

Fig. 29. Temperature/rabbit survey, AH-19.................. 26

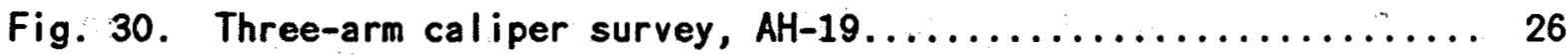

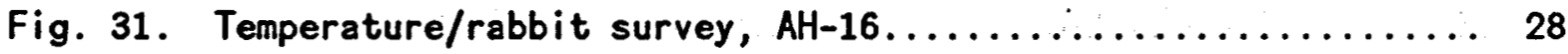

Fig. 32. Three-arm caliper survey, $A H-16 \ldots \ldots \ldots \ldots \ldots \ldots \ldots \ldots \ldots \ldots$

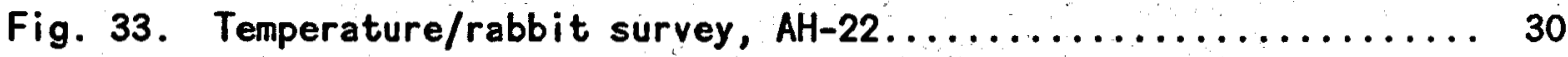

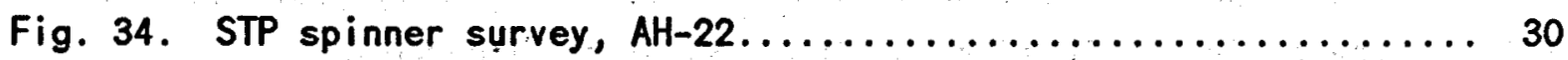

Fig. 35. Location map of Ahuachapan area showing locations of all wells and springs sampled for this investigation.......... 34

Fig. 36. Sketch of gas extraction system (GES) used for this investigation............................... 36

Fig. 37. Plot of $\mathrm{Na}$ versus $\mathrm{Cl}$ for fluid samples (corrected for steam flash where appropriate), Ahuachapán, El Salvador; boxes are geothermal well samples; dots are all other samples.....

Fig. 38. Plot of B versus Cl for fluid samples (corrected for steam flash where appropriate), Ahuachapán, El Salvador; symbols

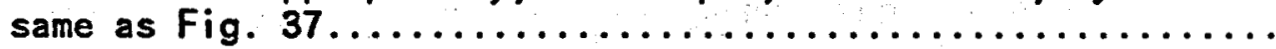

Fig. 39. Plot of As versus Cl for fluid samples (corrected for steam flash where appropriate), Ahuachapán, El Salvador; symbols same as Fig. 37; note split scale on both axes............ 44

Fig. 40. Plot of $\mathrm{Ca}$ versus $\mathrm{Cl}$ for fluid samples (corrected for steam flash where appropriate), Ahuachapán, El Salvador; symbols

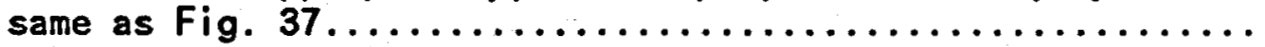

Fig. 41. Plot of $\delta D$ versus $\delta^{18} 0$ for fluid samples (corrected for steam flash where appropriate), Ahuachapán, El Salvador; symbols same as Fig. $37 \ldots \ldots \ldots \ldots \ldots \ldots \ldots \ldots \ldots \ldots \ldots \ldots$

Fig. 42. Plot of ${ }^{3} \mathrm{H}$ versus $\mathrm{Cl}$ for fluid samples (corrected for steam flash where appropriate), Ahuachapán, El Salvador; symbols same as Fig. 37; note split scale of $\mathrm{Cl}$ axis............ 51

Fig. A-1. The well logging truck....................... 60

Fig. A-2. The cablehead assembly...................... 61

Fig. A-3. The temperature/rabbit tool .................... 62

Fig. A-4. Schematic diagram of the Los Alamos in situ fluid sampler used during this investigation....................63

Fig. A-5. The three-arm caliper tool..................... 65

Fig. A-6. The spinner/temperature/pressure tool...............66 


\section{LIST OF TABLES}

page

TABLE I. Well Completion Schedule, Phase I............... 5

TABLE II. Completion Schedule, Phase II ................. 18

TABLE III. Field Data of Hell, Spring, Fumarole, and Surface

Samples, Ahuachapán, El Salvador.................. 33

TABLE IV. Water Analyses of Well, Spring, and Surface Samples,

Ahuachapán, El Salvador....................... 37

TABLE V. Trace Element Analyses of Water Samples, Ahuachapán, El Salvador............................... 38

TABLE VI. Gas Analyses of Well and Fumarole Samples, Ahuachapán, EI Salvador................................ 40

TABLE VII. Isotopic Data on Waters from Springs and Wells, Ahuachapán, El Salvador....................... 47

TABLE VIII. Tritium Concentration and Residence Times for Selected Base Years in Central America, Well-mixed Case........... 52

TABLE IX. Chemical Geothermometry of Hot Spring, Fumarole, and Well Samples, Ahuachapán, El Salvador............... 54

TABLE X. Calculated Downhole Compositions of the Two Most Concentrated Horizons Sampled During this Project, Ahuachapán, El Salvador. 


\section{EXECUTIVE SUMMARY}

This report is the first in a three-part series summarizing work performed at the El Salvador Ahuachapan geothermal field. This work was performed by Los Alamos, its Salvadoran counterpart, La Comisión Ejecutiva Hidroeléctrica del Rio Lempa (CEL), and other consultants. It was funded by the US Agency for International Development (USAID). This report deals specifically with well logging data and water samples collected on-site and their subsequent analyses, from late 1987 until early 1989. The next report in this series (Part 2), being prepared principally by Jim Fink of Tucson, Arizona, will deal with dc resistivity studies conducted during the same period. Part 3 , written by Lawrence Berkeley Laboratory (LBL), will deal with reservoir modeling.

Los Alamos became involved in these studies principally because of its experience in designing and operating downhole tools in geothermal environments (e.g., the Hot Dry Rock geothermal project) and in analyzing geothermal brine environments. The Ahuachapan geothermal field is of interest because of its declining pressure and temperature characteristics over time (Fig. i). Because of these declining features, the Ahuachapan plant currently produces only about $50 \%$ of its $95-M W e$ installed capacity. If successful, the well logging program will define problems in individual wells and identify the productive horizons of the reservoir, while the geochemistry will help define the overall reservoir characteristics and the recharge system. The dc resistivity measurements will identify the deeper reservoir structure. The reservoir engineering modeling work will define field expansion areas and establish a fluid reinjection program.

The well logging missions described here show that the maximum temperatures in the geothermal wells in the Ahuachapán geothermal field approach $250^{\circ} \mathrm{C}$. Well head pressures were found to be as high as $2.04 \mathrm{MPa}$ ( $300 \mathrm{psi}$ ) and flow rates reached $80 \mathrm{~kg} / \mathrm{s}$. The downhole instruments and associated equipment were capable of continuous and repeated performance in this severe geothermal environment. The actual well head pressures in some wells were, however, higher than initially anticipated, and these high pressures caused problems when logging tools were first started downhole. This was especially true for the lighter spinner/temperature/pressure (STP) tool. 


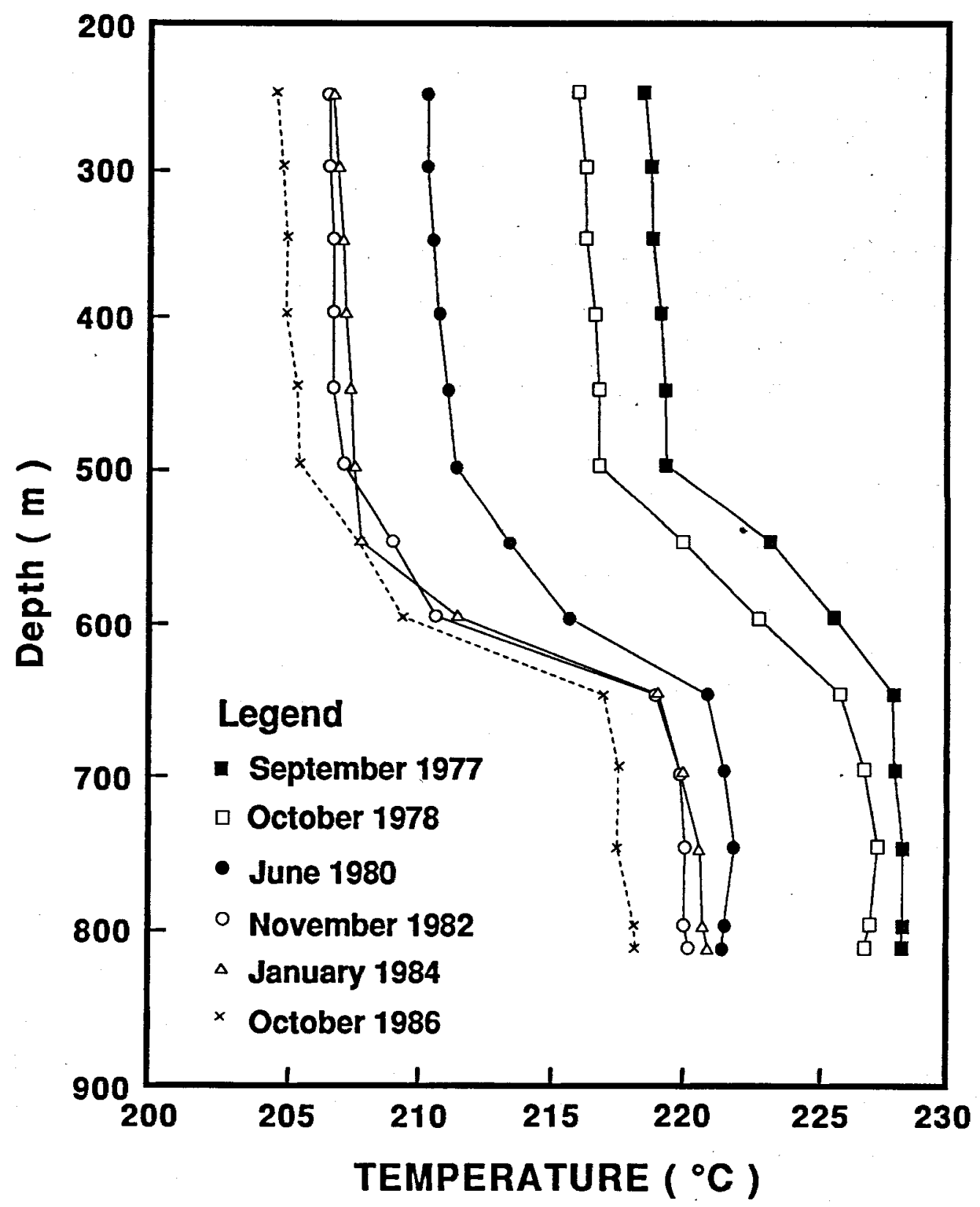

Fig. i. Selected temperature logs for well AH-21 (from CEL data). 
The high-temperature STP and the three-arm caliper tools provided the data necessary to determine the thermodynamic fluid properties of the production wells when wellbore conditions permitted. That is, for the thermodynamic analysis to be meaningful, casing, liner, and openhole diameters of the completed well sections have to be known. Also, a liquid-to-vapor interface must be well defined with the liquid region deep enough to provide the in situ calibration of the respective downhole transducers.

A schematic cross section through the Ahuachapán geothermal field (Fig. ii) presents our basic interpretation of the system configuration based upon geochemical interpretation. Our model is essentially the same as that proposed by Laky et al. (1989). Although our isotope data on cold meteoric waters surrounding the Ahuachapán region are not comprehensive, they suggest that recharge to the system is fairly localized (possibly from the volcanic highlands south of the field). Fluids percolate slowly to depths greater than $1200 \mathrm{~m}$ and equilibrate at $240^{\circ}$ to $260^{\circ} \mathrm{C}$. Isotopic variations suggest subtle differences in recharge elevation and/or reservoir processes, and striking variations in chemistry/chemical geothermometry indicate that Ahuachapán is not one homogeneous reservoir. Tritium data suggest a mean residence time of water in the reservoir of roughly $700 \mathrm{yr}$, although this interpretation is based on only a few analyses of the deep fluid.

According to Laky et al. (1989), fluids rise convectively in the general vicinity of the Laguna Verde Volcano and flow laterally to the north. These authors suggest that the lateral flow system branches with separate tongues of water flowing west to Ahuachapán and east to Chipilapa. Our temperature data, obtained during logging operations, agree with this interpretation because temperature reversals are seen in most wells, with highest temperatures occurring to the south of the field. Subsurface boiling creates fumaroles and acid-sulfate manifestations along faults above the main Ahuachapan production reservoir area and its internal flow system. Hot springs containing less than or equal to $10 \%$ of reservoir fluid occur above the lateral flow system several kilometers northeast of the geothermal field.

Hot springs and shallow hot wells of mixed composition indicate that cooler dilute fluids occurred above the geothermal system before production began (see also, Laky et al., 1989). Encroachment of these dilute fluids into deeper production zones has occurred since at least 1981 and is caused by 


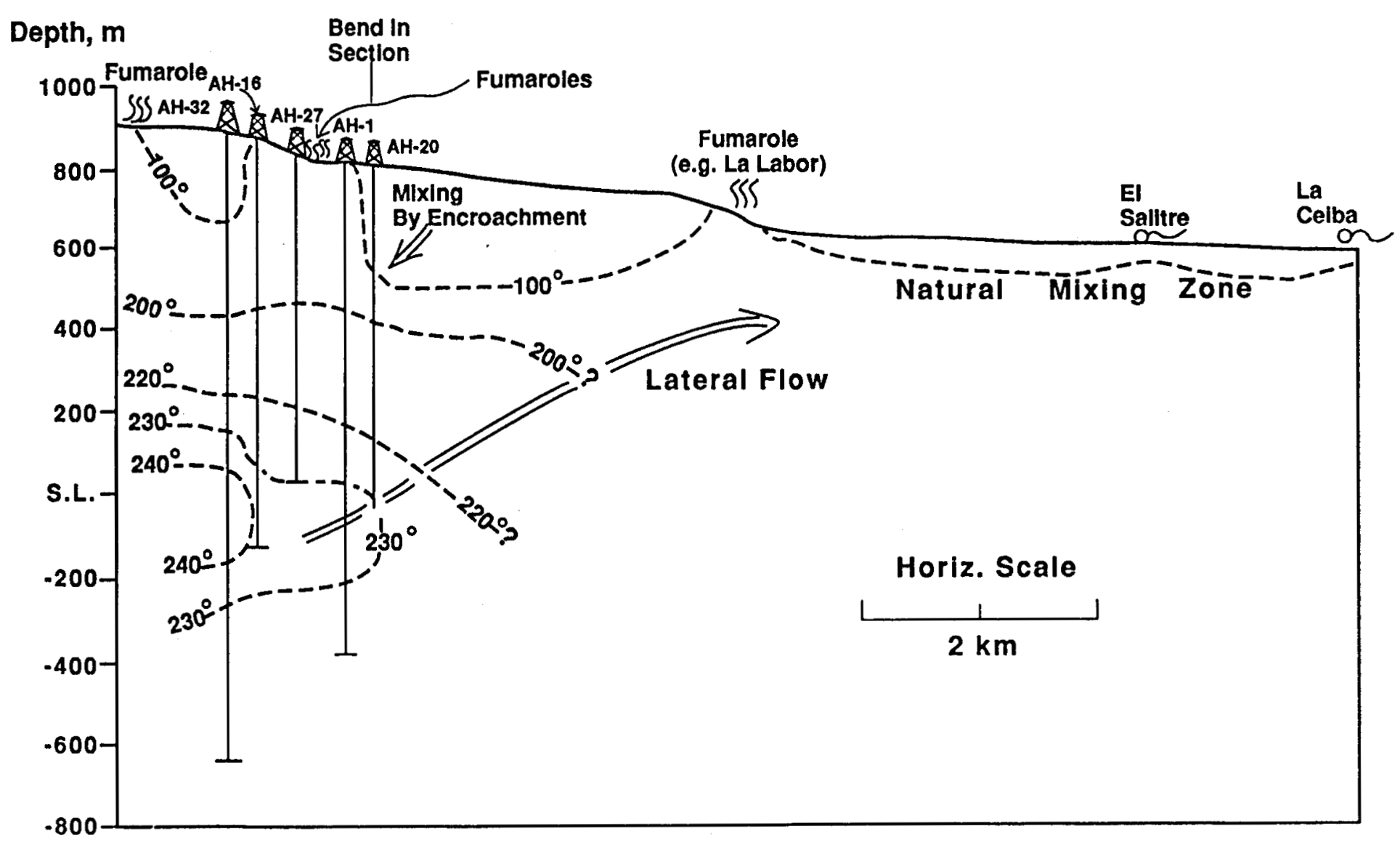

Fig. ii. Schematic south to north-northeast cross section through Ahuachapán geothermal field showing general configuration of geothermal system in relation to geothermal wells and hot springs. 
pressure declines from overproduction (Steingrimsson et al., 1989; Truesdell et al., 1989). Our in situ chemical data from several wells show increasing concentration with depth, consistent with encroachment. Our data also suggest that wells $A H-16$ and $A H-18$ are nonproducers due to limited permeability probably caused by precipitation of minerals in the formation. They are not dry steam wells. 



\section{RESUMEN EJECUTIVO}

E1 informe aquí presentado es el primero en una serie de tres que dan un resumen de los estudios llevados a cabo en el campo geotérmico de Ahuachapán en El Salvador. Esta investigación se hizo por Los Alamos, la institución contraparte en El Salvador (La Comisión Ejecutiva Hidroeléctrica del Río Lempa -- CEL) y otros consultores. Dicha investigación fue apoyada por la Agencia para el Desarrollo Internacional de los Estados Unidos (USAID). Este informe trata especificamente de los datos sobre los registros de pozos y muestras de agua recogidas en el sitio y su subsiguiente análisis, desde fines del año 1987 hasta principios de 1989. El próximo informe de esta serie, (Parte 2), actualmente en preparación y escrito principalmente por el Sr. Jim Fink de Tucson, Arizona, informará sobre los estudios de resistividad cc. terminados durante el mismo período de tiempo. En la Parte-3, escrita por Lawrence Berkeley Laboratory (LBL), se examinará modelación de reservorio.

Los Alamos entró en estos estudios principalmente por haber tenido experiencia en el diseño y operación de sondas pozo abajo en ambientes geotérmicos (por ejemplo, el proyecto geotérmico Hot Dry Rock) y en los análisis de ambientes geotérmicos salinos. Nos interesa el campo geotérmico de Ahuachapán por sus temperaturas y presiones que disminuyen con el tiempo (Figura i.) Debido a dichas condiciones decrecientes, actualmente 1 a planta de Ahuachapán produce solamente alrededor de $50 \%$ de su capacidad instalada de 95 MWe. Si el programa de registros de pozo tiene éxito, podrá definir problemas espécificos de los varios pozos e identificar los alcances productivos del reservorio, mientras que la geoquímica ayudará a definir las caracteristicas del reservorio entero y su sistema de recarga. Las medidas de resistividad cc. identificarán la estructura más profunda del reservorio. El modelo de ingeniería del reservorio definirá las áreas de expansión del campo y establecerá un programa de reinyección de fluidos. 


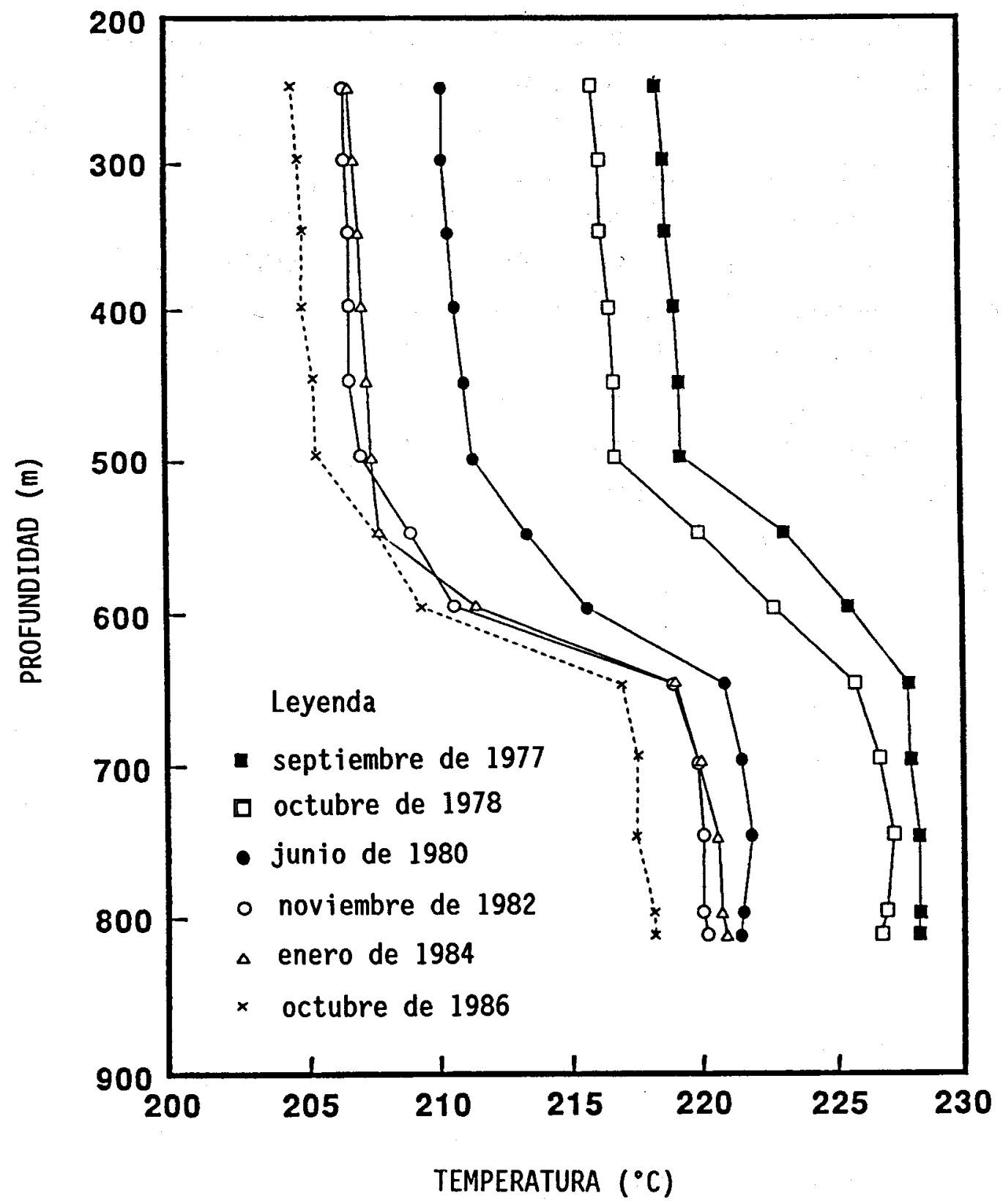

Figura i. Registros de temperatura seleccionados del pozo AH-21 (datos de la (EL). 
Los estudios de registro de pozos aquí descritos demuestran que las temperaturas máximas de los pozos geotérmicos del campo de Ahuachapán se aproximan a $250^{\circ} \mathrm{C}$. Las presiones de cabezal de pozo alcanzaron a $2.04 \mathrm{MPa}$ (300 psi) y la velocidad de flujo era de $80 \mathrm{~kg} / \mathrm{s}$. Los instrumentos de pozo abajo y el equipo relacionado aguantaron el uso continuo y repetido dentro del ambiente geotérmico severo. Sin embargo, se encontraron las presiones reales de cabezal de algunos pozos más altas que inicialmente se anticiparon $y$ dichas presiones altas causaron problemas cuando al principio se introdujeron intrumentos de registro pozo abajo. Especialmente fue asi en el caso de la sonda menos pesada de flujo/temperatura/presión (FTP).

Cuando las condiciones interiores de los pozos así 10 permitieron, el FTP de alta temperatura y las sondas de calibrador de tres brazos proveyeron los datos necesarios para determinar las características del fluido termodinámico en los pozos de producción. Es decir, para obtener un análisis termodinámico correcto, se tiene que saber los diámetros de la tubería de producción, de la tubería de revestimiento, y del interior del pozo. También se tiene que definir bien el interfase entre líquido y vapor, y la región líquida tiene que estar lo suficientemente profunda para proveer la calibración in situ de los transductores pozo abajo respectivos.

Un perfil esquemático transversal del campo geotérmico de Ahuachapán (Figura ii) indica nuestra interpretación básica en cuanto a la configuración del sistema basándose en las interpretaciones geoquímicas. Nuestro modelo es esencialmente 10 mismo que el propuesto por la Sra. Laky $y$ otros (1989). Aunque nuestros datos de isótopos sobre las aguas meteóricas frías circunvecinas a la región de Ahuachapán no son completos, ellos sugieren que la recarga de agua al sistema es de origen bastante local (posiblemente de las tierras altas volcánicas al sur del campo). Los fluidos filtran lentamente a profundidades mayores de $1.200 \mathrm{~m}$ y se equilibran entre $240^{\circ}$ a $260^{\circ} \mathrm{C}$. Las variaciones isotópicas indican diferencias casi imperceptibles entre los niveles de recarga de agua $y / 0$ 


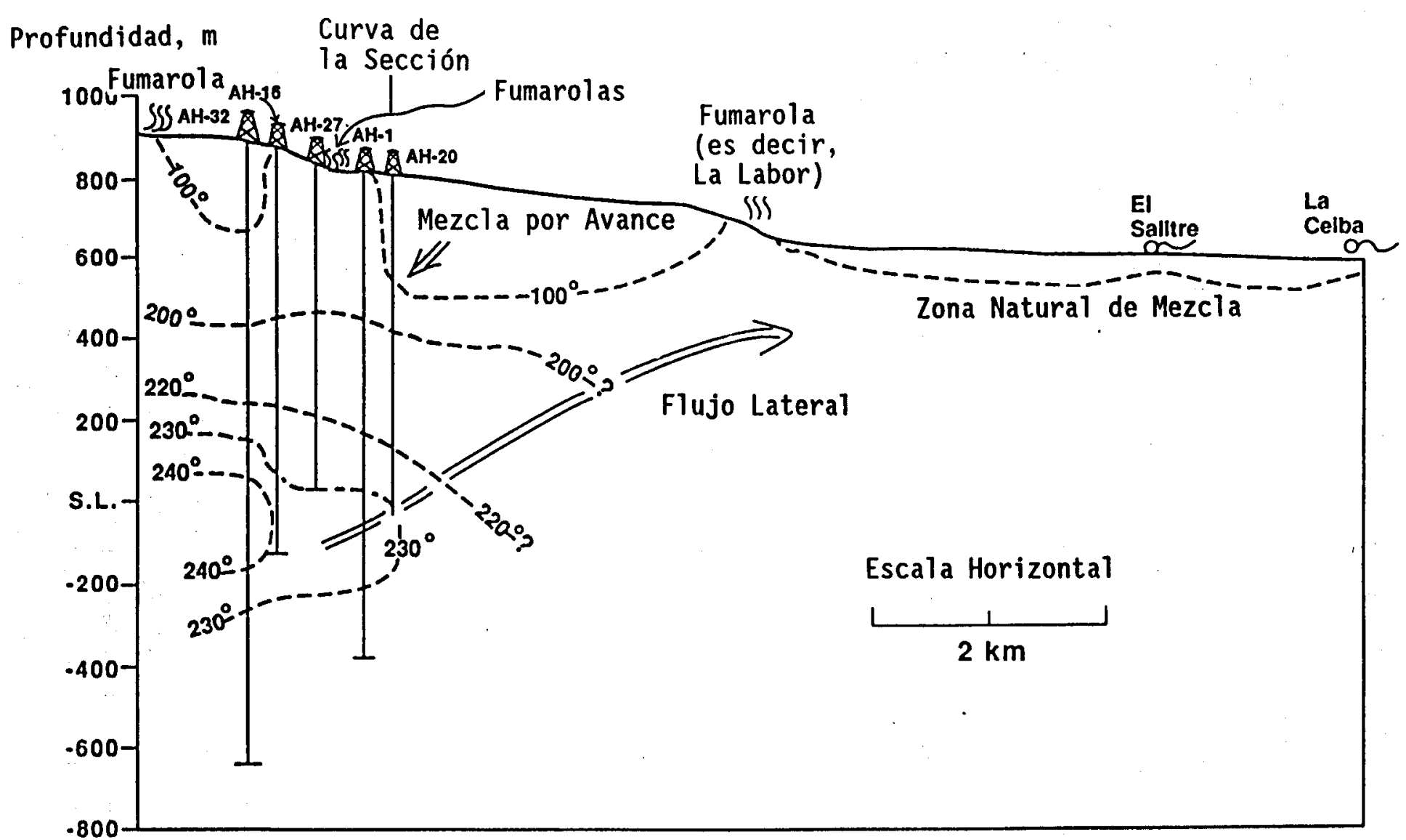

Figura ii. Un perfil esquemático transversal desde el sur hacia el nornordeste del campo geotérmico de Ahuachapán en donde se puede ver la configuración general del sistema geotérmico con relación a los pozos geotérmicos y manantiales calientes. 
Tos procesos de reservorio, así como variaciones notables en la química y la geotermometría química que indican que Ahuachapán no es un reservorio homogéneo. Los datos de tritio indican un tiempo medio de residencia de agua en el reservorio de aproximadamente 700 años, aunque esta interpretación se basa sólamente en unos pocos análisis de fluidos profundos.

Según la Sra. Laky y otros (1989), los fluidos suben por convección en la vecindad general del volcán Laguna Verde y fluyen lateramente hacia el norte. Dichos autores sugieren que el sistema de flujo lateral se ramifica, con unos de los ramales yendo al oeste hacia Ahuachapán y otros al este hacia Chipilapa. Nuestros datos de temperatura, obtenidos durante las operaciones de registro de pozo, están de acuerdo con esta interpretación porque las inversiones de temperatura se evidencian en la mayoría de los pozos, con la incidencia de temperaturas más altas al sur del campo. La ebullición subterránea crea fumarolas y manifestaciones de ácido sulfato a 10 largo de las fallas más arriba del reservorio de producción principal de Ahuachapán y su sistema de flujo interno. Ocurren manantiales calientes con $10 \%$ o menos del fluido del reservorio más arriba del sistema de flujo láteral y a varios kilómetros al nordeste del campo geotérmico.

Los manantiales calientes y pozos de agua caliente poco profundos de composición mezclada indican que fluidos diluidos más fríos ocurrieron más arriba del sistema geotérmico antes de comenzar la producción (vea también el informe de la Sra. Laky y otros, 1989). El avance de estos fluidos diluidos a las zonas más profundas de producción ha ocurrido desde por 10 menos 1981 y está causado por una disminución de presión debido a la sobreproducción (Steingrimsson y otros, 1989; Truesde11 y otros, 1989). Nuestros datos químicos in situ de varios pozos demuestran un aumento de la concentración en función de la profundidad, consistente con el grado del avance. Nuestros datos también sugieren que los pozos AH-16 y AH-18 no producen debido a la permeabilidad limitada, probablemente causada por la precipitación de minerales en la formación. No son pozos de vapor seco. 


\title{
RESULTS OF INVESTIGATIONS AT THE \\ AHUACHAPAN GEOTHERMAL FIELD, EL SALVADOR
}

PART 1: WELL LOGGING AND BRINE GEOCHEMISTRY

\author{
Compiled by
}

Bert Dennis, Fraser Goff, Ed Van Eeckhout, and Bob Hanold

\section{ABSTRACT}

Well logging operations were performed in eight of the geothermal wells at Ahuachapán. High-temperature downhole instruments, including a temperature/rabbit, caliper, fluid velocity spinner/temperature/pressure (STP), and fluid sampler, were deployed in each well. The caliper tool was used primarily to determine if chemical deposits were present in well casings or liners and to investigate a suspected break in the casing in one well. STP logs were obtained from six of the eight wells at various flow rates ranging from 30 to $80 \mathrm{~kg} / \mathrm{s}$. A static STP log was also run with the wells shut-in to provide data to be used in the thermodynamic analysis of several production wells.

The geochemical data obtained show a system configuration like that proposed by C. Laky and associates in 1989. Our data indicate recharge to the system from the volcanic highlands south of the field. Additionally, our data indicate encroachment of dilute fluids into deeper production zones because of overproduction.

\section{INTRODUCTION}

The Ahuachapan geothermal field is located in the northwest section of EI Salvador about $120 \mathrm{~km}$ from San Salvador (Fig. 1). The first geothermal electric power generating plant in Central America came on-line in 1975 at Ahuachapán. Its generating capacity grew from an initial 30 MW to 95 MW in 


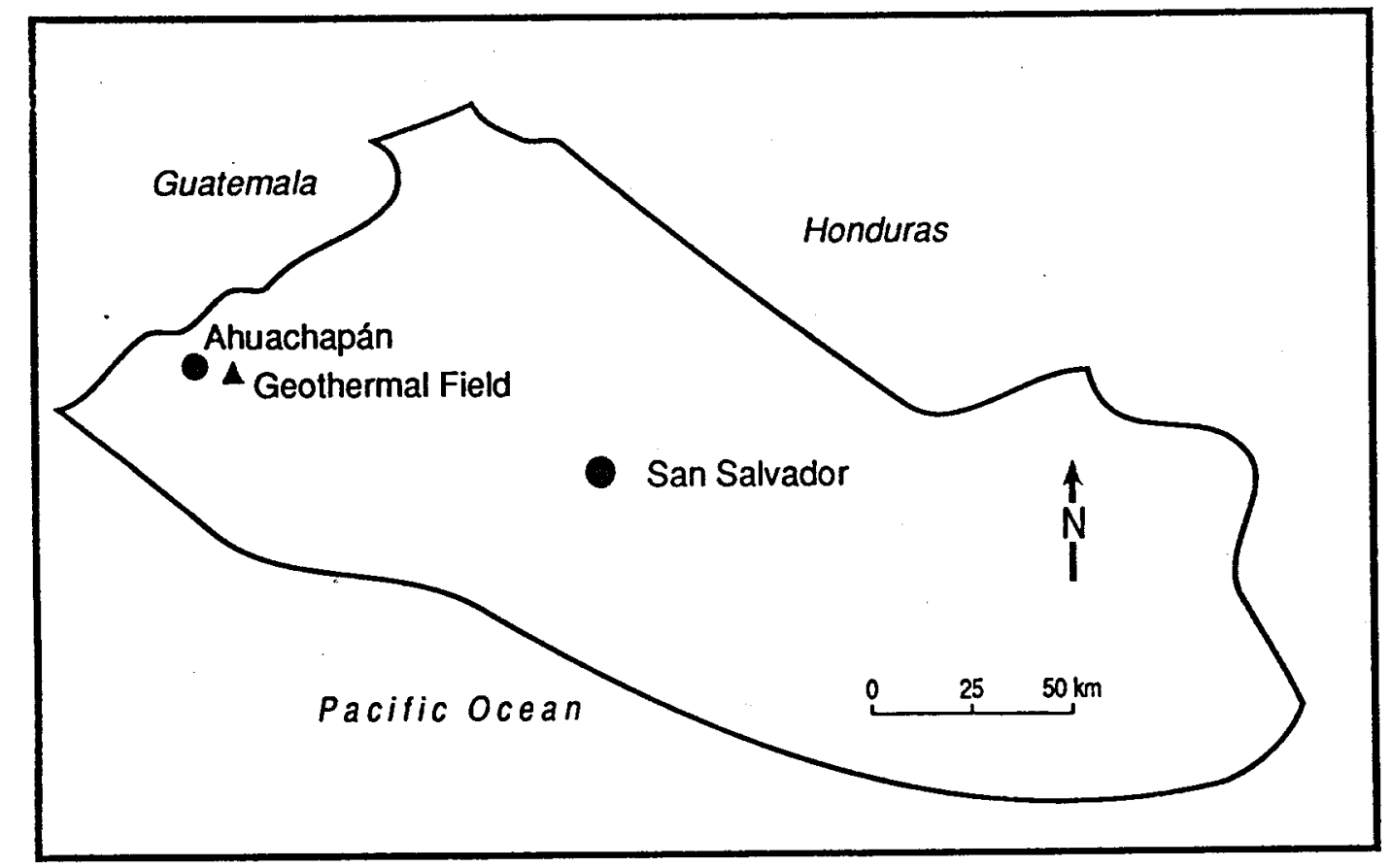

Fig. 1. Schematic map of El Salvador showing location of Ahuachapán.

a 6-year period. Over 40 wells have been drilled in the Ahuachapan field. The high-quality geothermal resource at one time produced $42 \%$ of the electrical power used in EI Salvador. In recent years, however, power plant output has dropped, primarily because well production has decreased.

The Los Alamos well logging and geochemistry team, in collaboration with La Comisión Ejecutiva Hidroeléctrica del Río Lempa (CEL), the agency of the Salvadoran government responsible for Ahuachapan geothermal operations, focused on the problem of declining well production. Using the high-temperature logging tools developed at Los Alamos, the team made downhole measurements to determine whether production declines could be attributed to individual well damage, reduction in the central reservoir pressure, or a combination of these and other factors. The well logging data were also to be used to improve existing reservoir models of the Ahuachapan field and used for an integrated reservoir engineering investigation that will culminate in the design and implementation of an effective spent-brine reinjection program. 


\section{WELL LOGGING OPERATIONS}

\section{A. Phase I}

Phase I of the Ahuachápán logging operations was performed in September 1987 and involved four wells: AH-1, $-18,-20$, and -27 (Fig. 2). Wells AH-1 and $A H-27$ are located in the central part of the field, AH-20 in the northern part, and AH-18 in the southeastern part of the main exploitation area. The completion schedule for each of the wells is presented in Table I.

$\underline{\mathrm{AH}-1}$

The first well to be logged, AH-1, was located near the base compound at well AH-6. A relatively large cleared area surrounded this well, which made it the best place to rig up the logging equipment for the first time. This well was used for safety training for operators. Well AH-1 had a static water level depth at $525 \mathrm{~m}$, the main production zone at $554 \mathrm{~m}$, and a maximum temperature of $225^{\circ} \mathrm{C}$. The maximum flow rate was $54 \mathrm{~kg} / \mathrm{s}$ with a flowing well lhead pressure of $40.68 \mathrm{kPa}$ (5.9 psi). The shut-in pressure could build up to $1.71 \mathrm{MPa}$ (248 psi).

A temperature survey was run in AH-1 from the surface to a depth of $1100 \mathrm{~m}$ (Fig. 3). The temperature tool had the ring gauge or "rabbit" attached to provide clearance information regarding this well bore before the more expensive downhole instruments were deployed (Fig. A-3). The temperature log, run with the well shut in (static), shows the water level or liquid-to-vapor interface at $590 \mathrm{~m}$. The casing in AH-1 was cemented to a depth of $457 \mathrm{~m}$ from the surface. The wellbore was open from $457 \mathrm{~m}$ to $1195 \mathrm{~m}$. The maximum temperature measured was $231^{\circ} \mathrm{C}$.

A 4- $\ell$ fluid sample was taken with the high-temperature fluid sampler at $1100 \mathrm{~m}$ (Fig. A-4). The well control valve in the vent line to the mufflers was adjusted to a flow rate of $30 \mathrm{~kg} / \mathrm{s}$ when the sample was obtained. The temperature probe in the fluid sampler measured $223^{\circ} \mathrm{C}$. A second fluid sample was obtained at a depth of $550 \mathrm{~m}$, and the measured temperature was $208^{\circ} \mathrm{C}$. The results of chemical analyses for all downhole samples are presented in this report, Section III.

The combination fluid velocity (spinner)/temperature/pressure (STP) instrument provides the data necessary to investigate the thermodynamic 


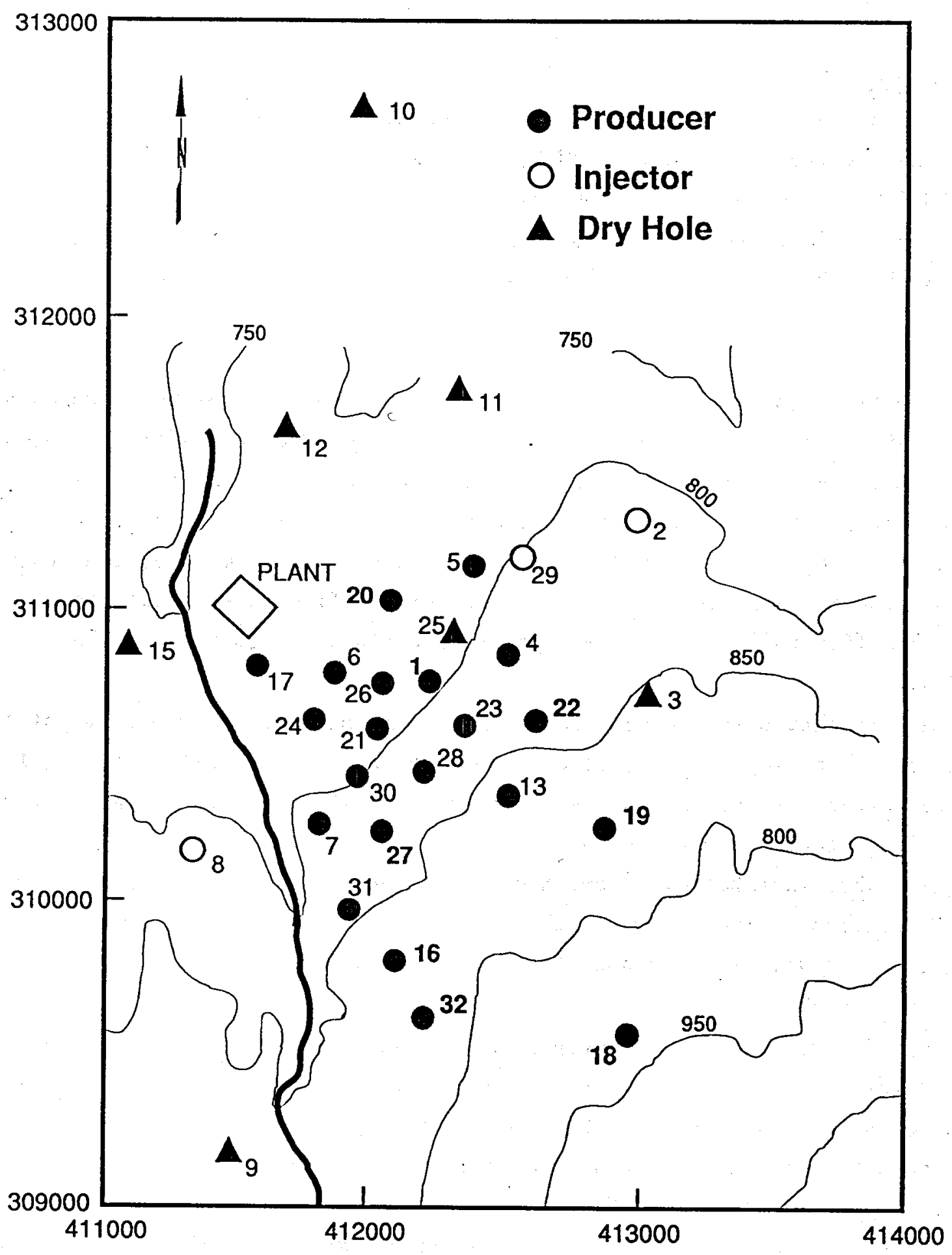

Fig. 2. Map of the Ahuachapán geothermal field showing well locations. 
TABLE I. WELL COMPLETION SCHEDULE, PHASE I

Well Number

\begin{tabular}{lccccc} 
& AH-1 & AH-18 & & AH-20 & AH-27 \\
\cline { 2 - 3 } Casing diameter, mm & 244.5 & 244.5 & 340 & 244.5 \\
Liner diameter, mm & none & 193.7 & 244.5 & 193.7 \\
Openhole diameter, mm & 222.3 & na & na & 216 \\
Bottom of casing, m depth & 457 & 634 & 449 & 412 \\
Top of liner, m depth & -- & 614 & 423 & 333 \\
Bottom of liner, m depth & -- & 1256 & 850 & 729 \\
Bottom of hole, m depth & 1195 & 1259 & 853 & 780
\end{tabular}

$193.7 \mathrm{~mm}$ (7-5/8 in.), $223.3 \mathrm{~mm}(8-3 / 4 \mathrm{in.}), 216 \mathrm{~mm}(8-1 / 2 \mathrm{in.}), 244.5 \mathrm{~mm}(9-5 / 8$ in.), $340 \mathrm{~mm}(13-3 / 8 \mathrm{in.})$.

behavior of the geothermal well fluids (Fig. A-6). Mass flow rates can be calculated when the fluid density, flow area, and fluid velocity are known. Fluid densities can be determined if the temperatures, pressures, and vapor qualities are known. Vapor quality can be calculated if we assume no total heat loss (constant enthalpy) throughout the borehole and use the value of enthalpy at the liquid interface.

The STP tool was run in AH-1 starting at a depth of $100 \mathrm{~m}$ and logging the well to $1100 \mathrm{~m}$. The first survey was run with the well shut in (static) to provide for in situ calibration information for the pressure and spinner transducers. A second $\mathrm{log}$ was run with the well flowing at approximately $30 \mathrm{~kg} / \mathrm{s}$. The temperature data from this survey show that the vapor-to-liquid interface is at $600 \mathrm{~m}$ (Fig. 4), which agrees with the measured borehole pressure and calculated saturation pressure (based on temperature) intersection plotted in Fig. 5. The spinner output in hertz versus depth is plotted in Fig. 6. A problem with the trigger level in the electronic counter that measures spinner frequency inhibited data acquisition from $280 \mathrm{~m}$ to $410 \mathrm{~m}$ in 


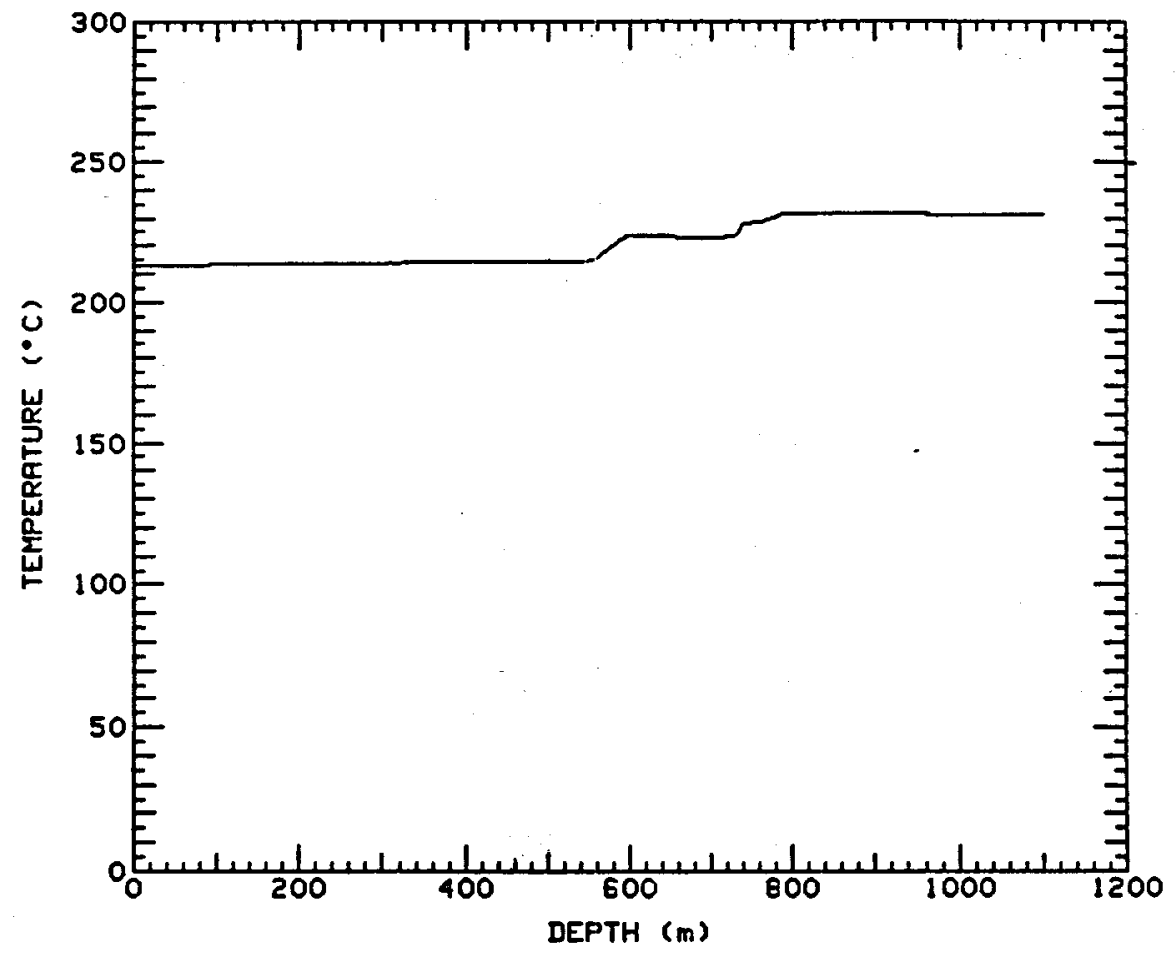

Fig. 3. Temperature/rabbit survey (static), AH-1.

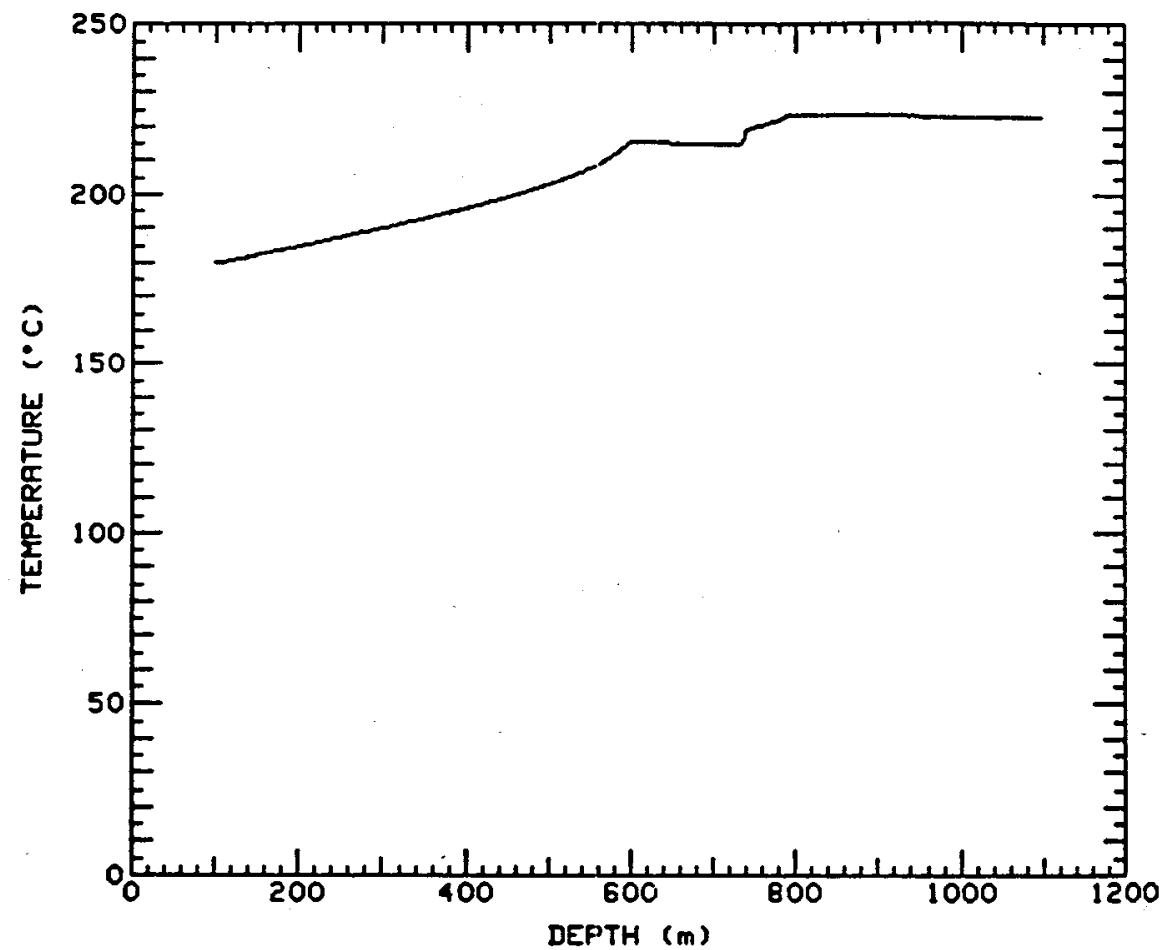

Fig. 4. STP temperature survey $(30 \mathrm{~kg} / \mathrm{s}), A H-1$. 


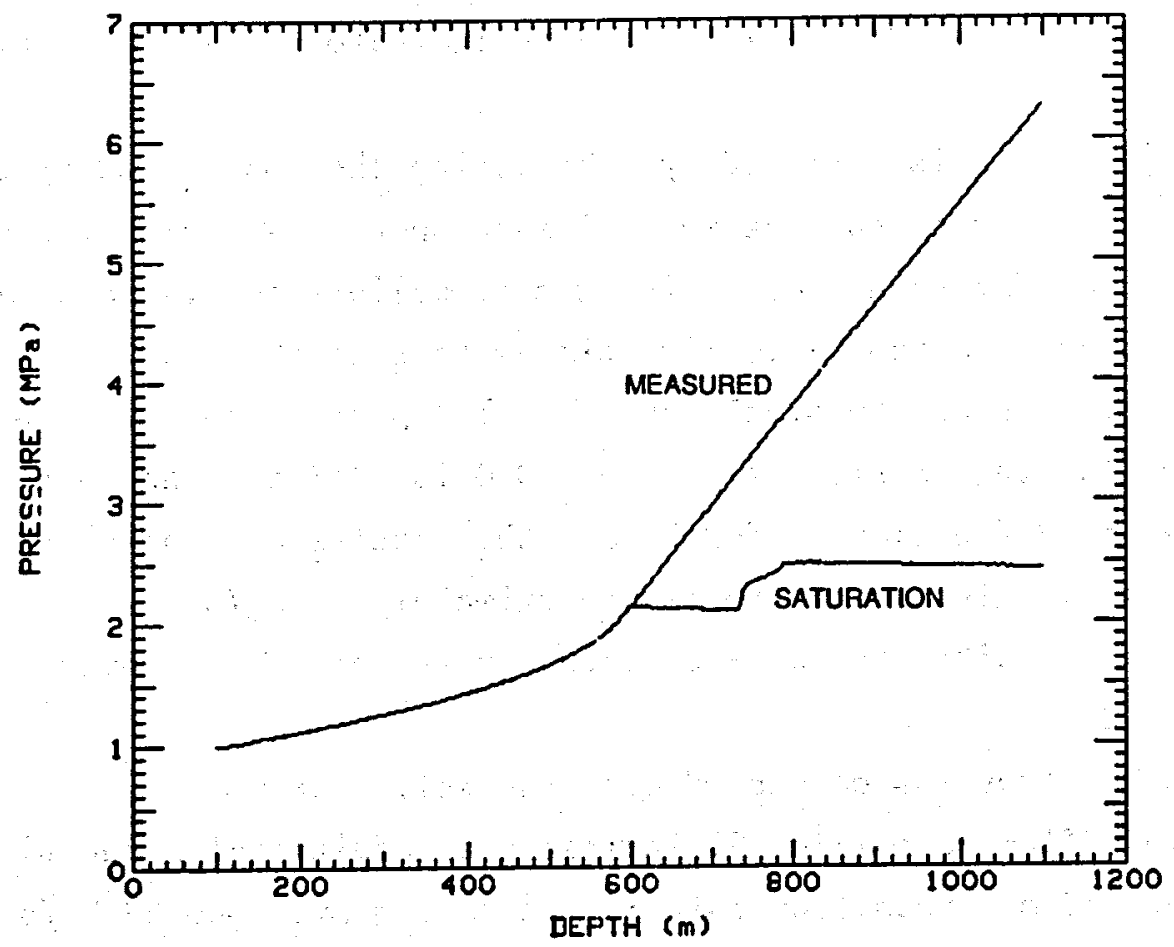

Fig. 5. Pressure data and saturation pressure $(30 \mathrm{~kg} / \mathrm{s}), A H-1$.

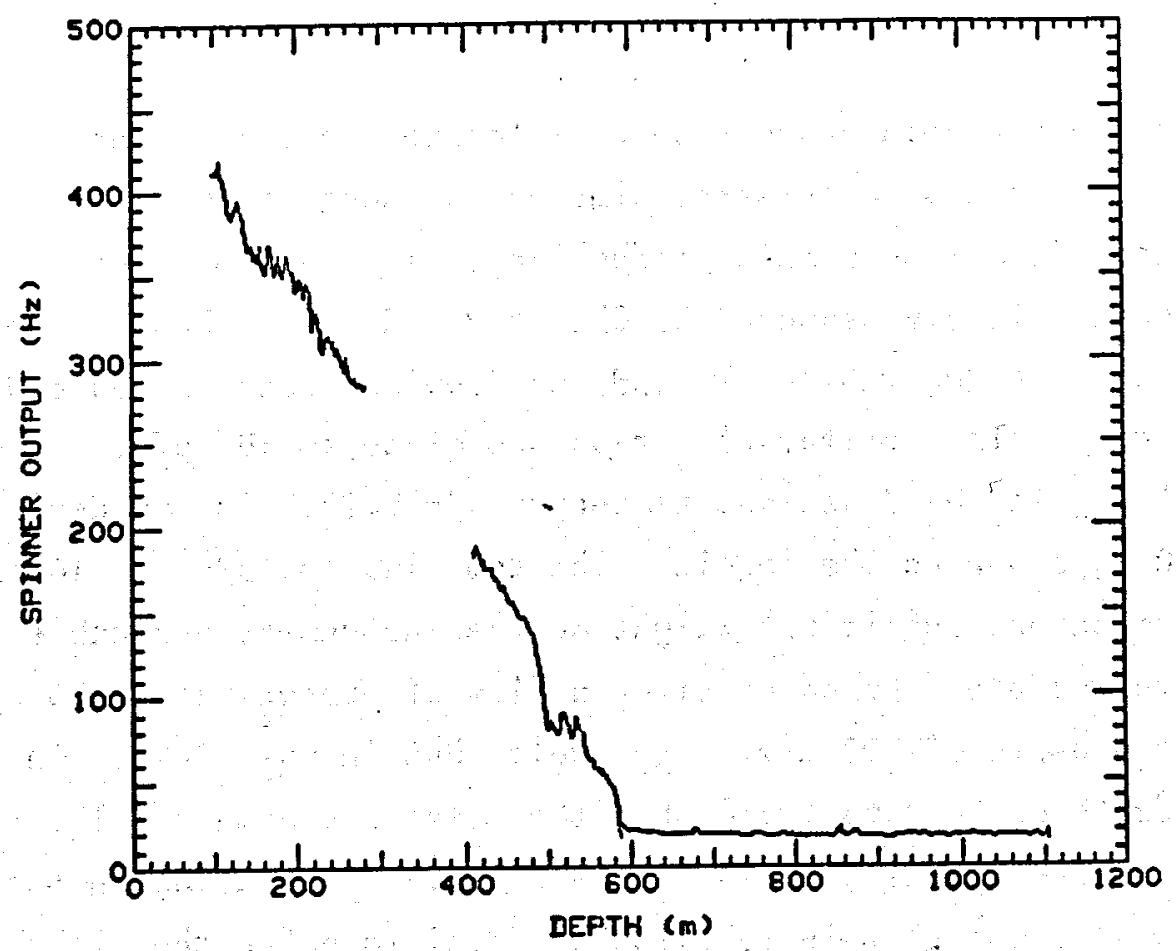

Fig. 6. STP spinner survey $(30 \mathrm{~kg} / \mathrm{s}), A H-1$. 
the vapor region of the well. This plot does indicate a major production zone around 500 to $580 \mathrm{~m}$.

The fluid velocity is obtained by subtracting the tool velocity or logging rate from the indicated spinner values. The spinner or velocity transducer is normally calibrated for each log. This in situ calibration is determined from the spinner data and the tool velocity (time-versus-depth data) in the liquid region of the well during the static survey. The proportionality constant used for the spinner for this series of logs was $0.0318 \mathrm{~m} / \mathrm{s} / \mathrm{Hz}$. The mass flow rates were calculated as a function of depth, and the results are shown in Fig. 7 . The average mass flow in the casing is approximately $30 \mathrm{~kg} / \mathrm{s}$. Vapor quality was also calculated using the value of enthalpy at the liquid interface and is plotted in Fig. 8.

A third STP survey was conducted with the well discharge valve fully opened. The mass flow rate (Fig. 9) indicates an additional production zone between 640 and $660 \mathrm{~m}$. Mass flow rate in the casing averages $58 \mathrm{~kg} / \mathrm{s}$, which is in agreement with the flow rate reported by CEL. Vapor quality for the higher flow rate is plotted in Fig. 10 .

\section{AH-27}

AH-27 was another good production well located in the center of the Ahuachapan field with characteristics similar to those of AH-1. The reported liquid level was $576 \mathrm{~m}$ with a main production zone at $425 \mathrm{~m}$. The maximum temperature was previously measured by $\mathrm{CEL}$ at $234^{\circ} \mathrm{C}$. The shut-in pressure at the well thead was $1.74 \mathrm{MPa}$ (252 psi), and the flowing pressure could drop to $482.6 \mathrm{kPa}$ (70 psi). The maximum flow rate was given as $56 \mathrm{~kg} / \mathrm{s}$.

The first $\log$ in AH-27 was the temperature/rabbit. It was decided to flow the well at $30 \mathrm{~kg} / \mathrm{s}$ during the log-in. The tool was deployed to $100 \mathrm{~m}$ with the well shut in to ensure sufficient weight on the instrument and cable. The well discharge valve was then opened to allow a flow of approximately $30 \mathrm{~kg} / \mathrm{s}$. Temperature at a depth of $100 \mathrm{~m}$ with the well shut in was $214^{\circ} \mathrm{C}$. The temperature at this depth dropped to $191^{\circ} \mathrm{C}$ when the valve was opened. The tool set down at $330 \mathrm{~m}$ at the top of the $194-\mathrm{mm}(7-5 / 8-\mathrm{in}$.$) liner going in the well. At$ this point the well was shut in to allow the tool to enter the liner. Flow was again established at $30 \mathrm{~kg} / \mathrm{s}$, and the $\log$ continued to $725 \mathrm{~m}$. The well was 


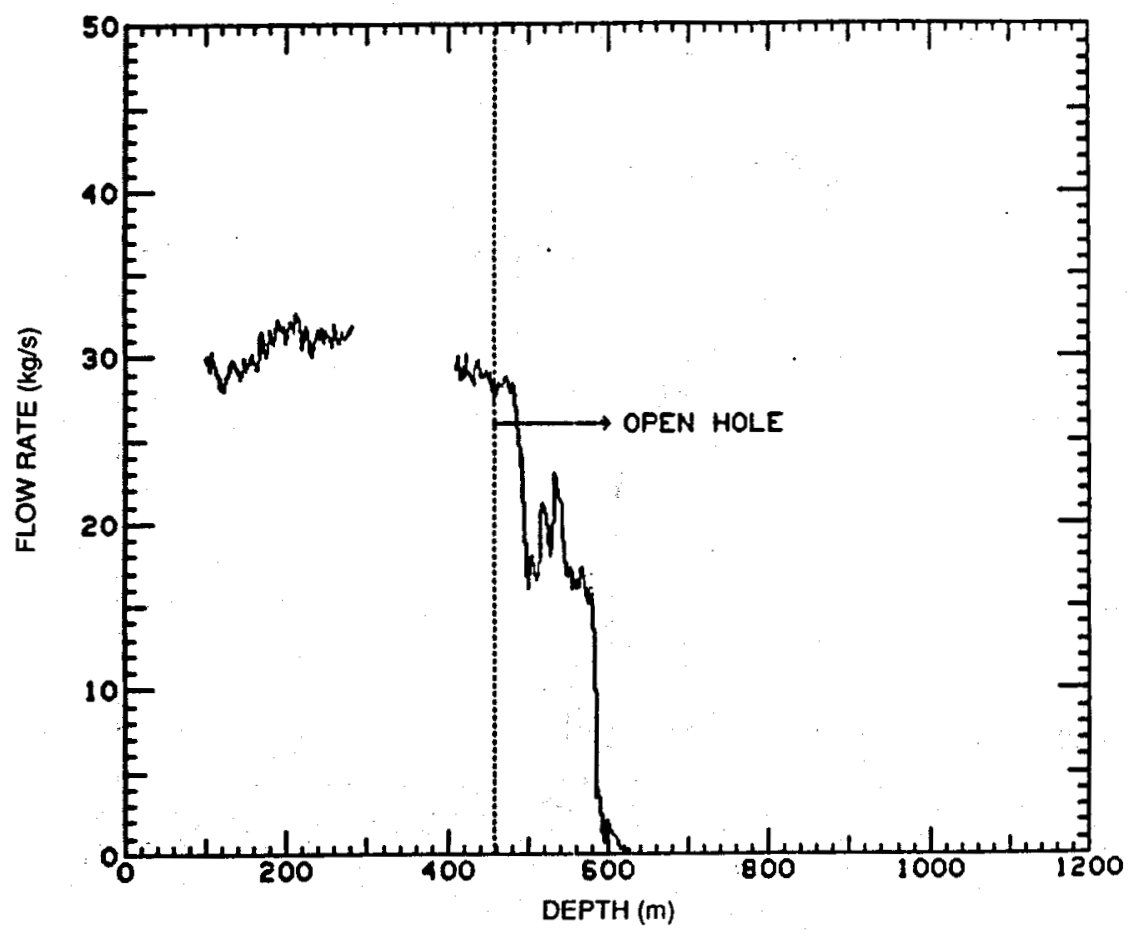

Fig. 7. Calculated flow rate $(30 \mathrm{~kg} / \mathrm{s}), \mathrm{AH}-1$.

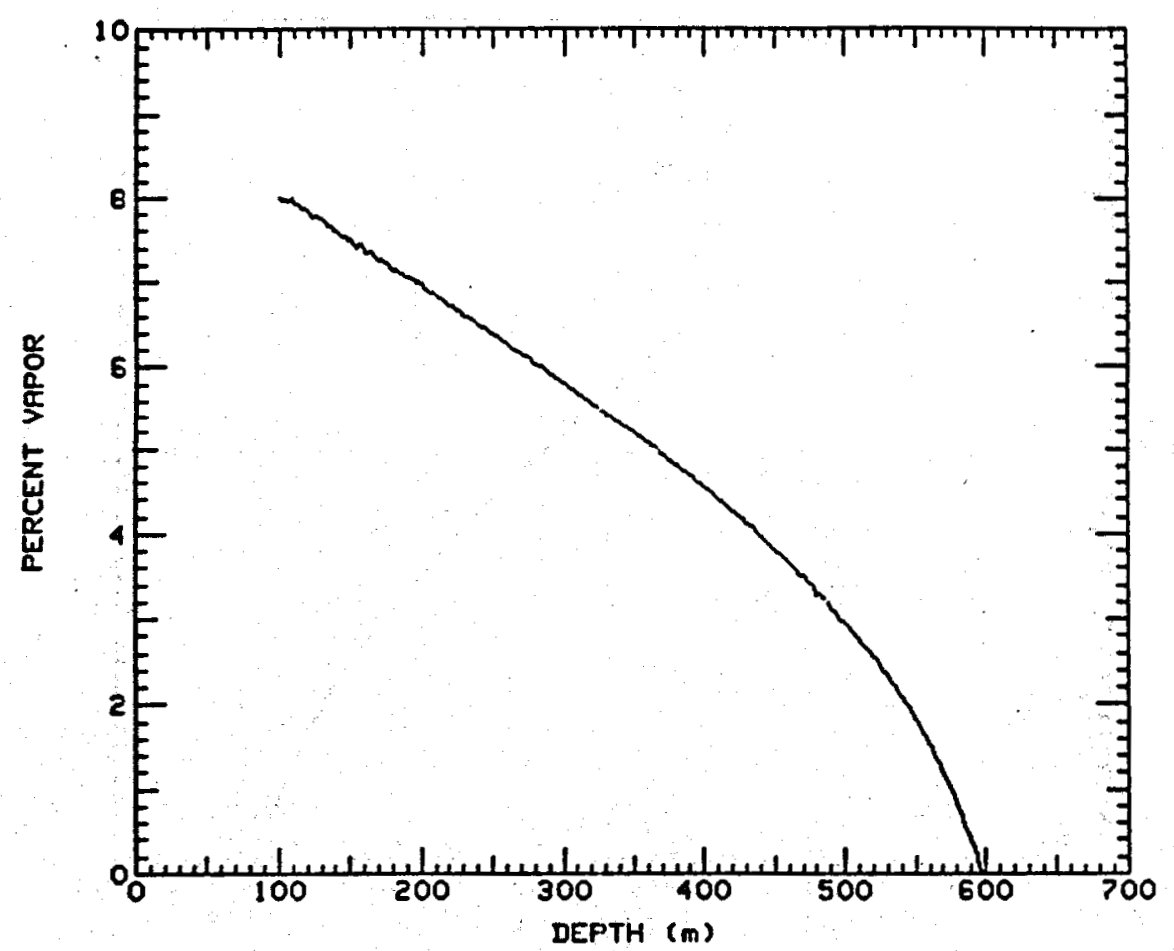

Fig. 8. Vapor quality $(30 \mathrm{~kg} / \mathrm{s}), A H-1$. 


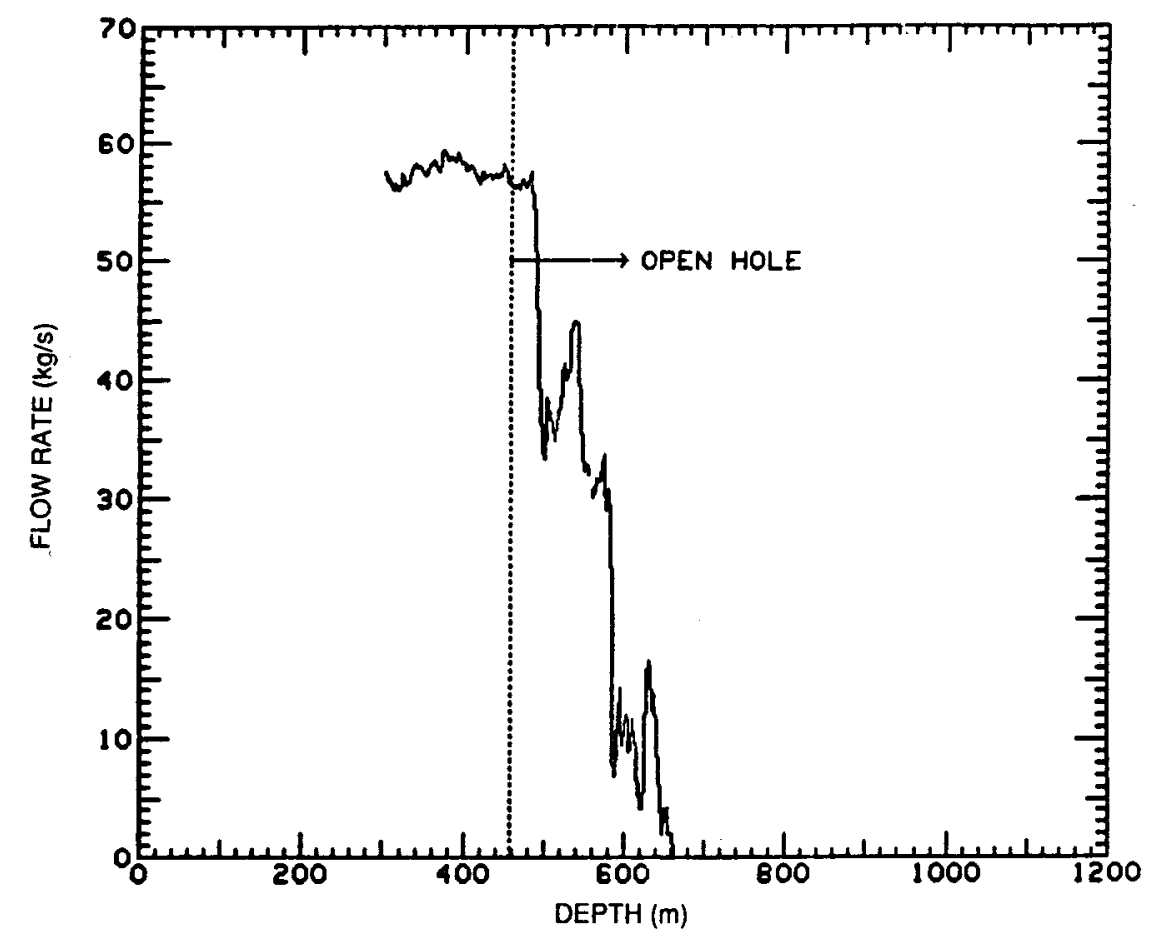

Fig. 9. Calculated flow rate $(58 \mathrm{~kg} / \mathrm{s}), \mathrm{AH}-1$.

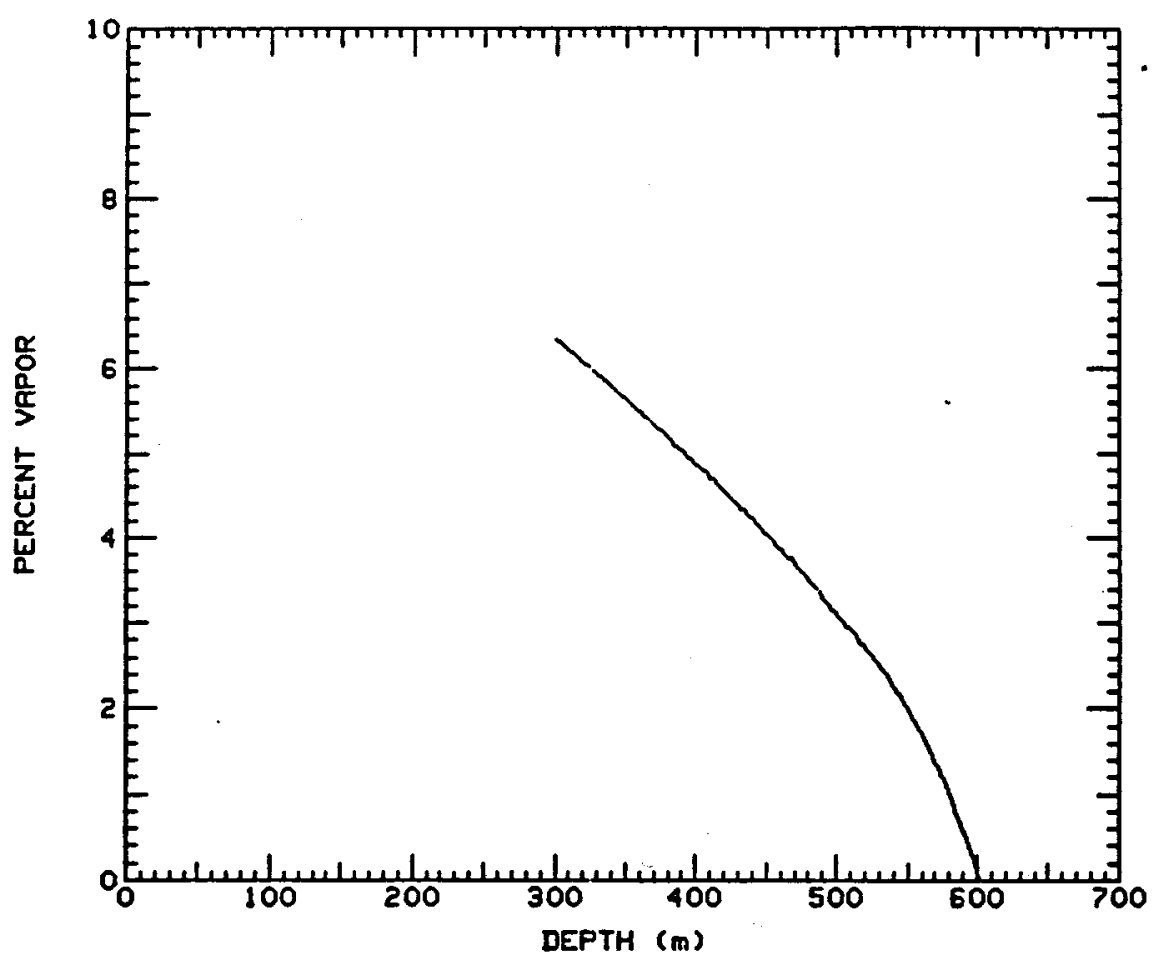

Fig. 10. Vapor quality $(58 \mathrm{~kg} / \mathrm{s}), \mathrm{AH}-1$. 
shut in to obtain a static log coming out of the well. Temperature data are shown in Fig. 11. The liquid-to-vapor interface was reached at $580 \mathrm{~m}$.

The STP tool was set in the pressure lock and rigged up over the well. The $\log$ was started at $100 \mathrm{~m}$ with the well flowing at approximately $30 \mathrm{~kg} / \mathrm{s}$. The spinner tool had been designed for lower flow rates of up to $25 \mathrm{~kg} / \mathrm{s}$, and the higher flow rates in the Ahuachapan wells ultimately damaged the impellers and bearings in the tool; the impellers on the spinner shaft: sheared off, and the spinner data were lost. The log was completed, but only the temperature and pressure were measured. The liquid/vapor interface occurs at $610 \mathrm{~m}$ with the mass flow approximately $30 \mathrm{~kg} / \mathrm{s}$.

A 4- $\ell$ fluid sample was obtained at a depth of $725 \mathrm{~m}$ (results are discussed in this report, Section III).

AH-20

AH-20 was of considerable interest because steam was emerging at the surface around the outside of the wellhead. Speculation was that a parted casing near the depth where the liner was hung might have damaged the well or • that the cement around the casing shoe had deteriorated. The well was shutdown by pumping cold water down the casing into the borehole. Other information received from CEL concerning $A H-20$ indicated a main production zone at $455 \mathrm{~m}$ with a secondary zone at $700 \mathrm{~m}$. The liquid/vapor interface was reported to be at $525 \mathrm{~m}$, and the maximum temperature was $219^{\circ} \mathrm{C}$. Before intervention in the well, static wellhead pressure was $1.47 \mathrm{MPa}$ (213 psi) and flowing pressure was $61.36 \mathrm{kPa}$ (8.9 psi).

Since $A H-20$ was in the shutdown status and cold water was still being pumped down the well, no pressure lock was required during the logging operations. The temperature/rabbit tool was deployed to a depth of $827 \mathrm{~m}$ where it set down $23 \mathrm{~m}$ above the bottom of the liner. The temperature log (Fig. 12) clearly shows the cold water interface and the area where fluid is leaving the wellbore. These data also indicate that this interface moves up and down the wellbore when the cold water pumps are turned on or off for short periods.

The STP log confirms the evidence that fluid is leaving the wellbore at $420 \mathrm{~m}$. (See the STP temperature data in Fig. 13 and the spinner output data in Fig. 14.) 


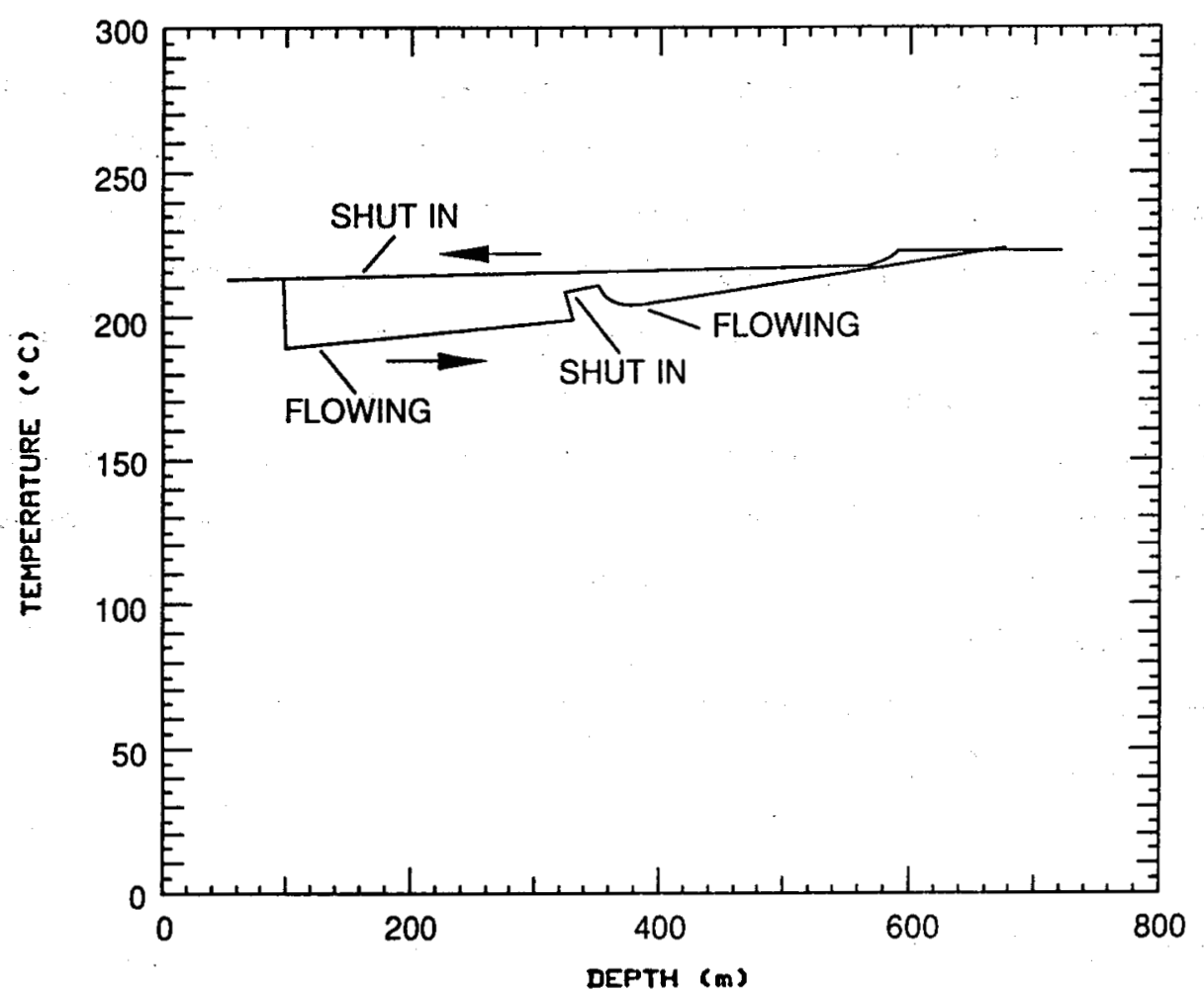

Fig. 11. Temperature/rabbit survey, AH-27.

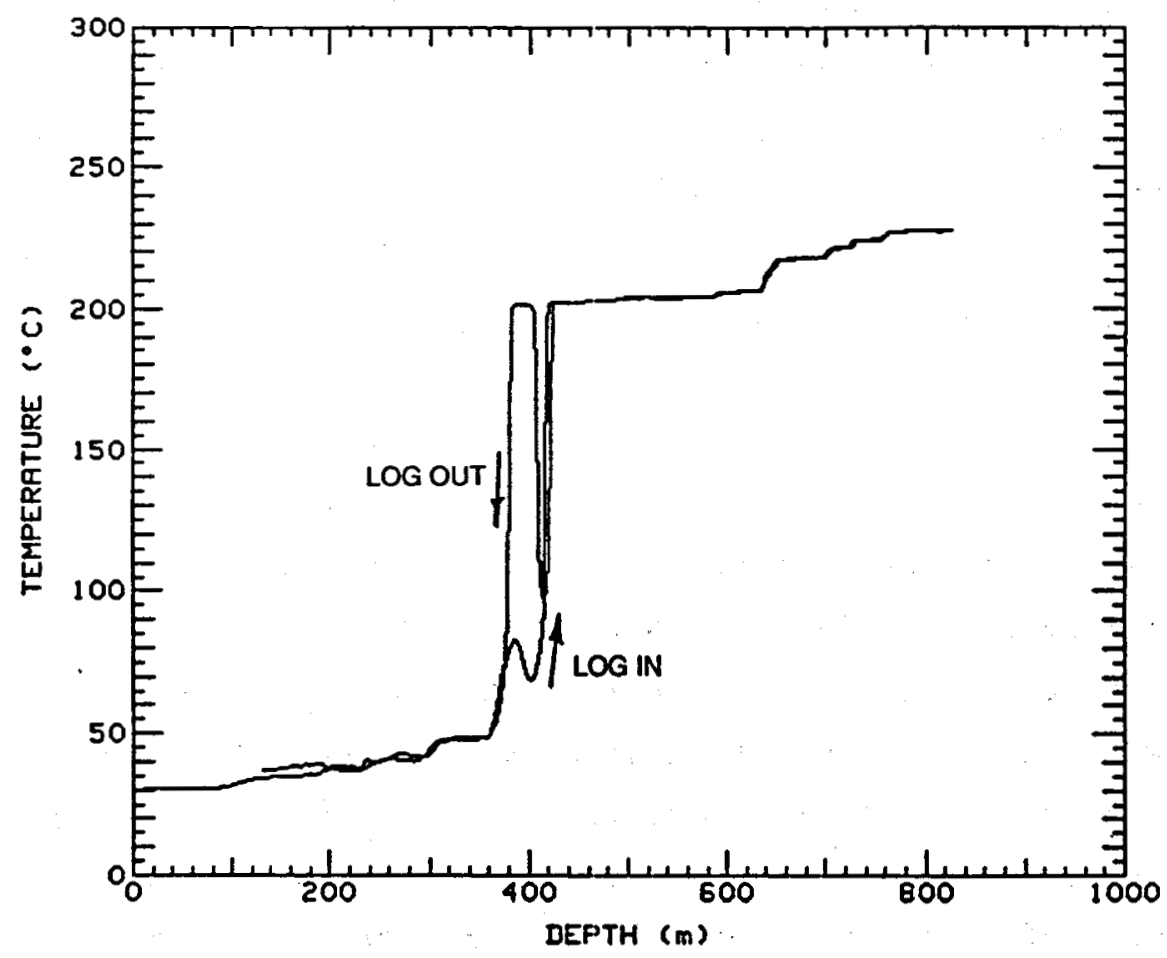

Fig. 12. Temperature/rabbit survey, AH-20. 


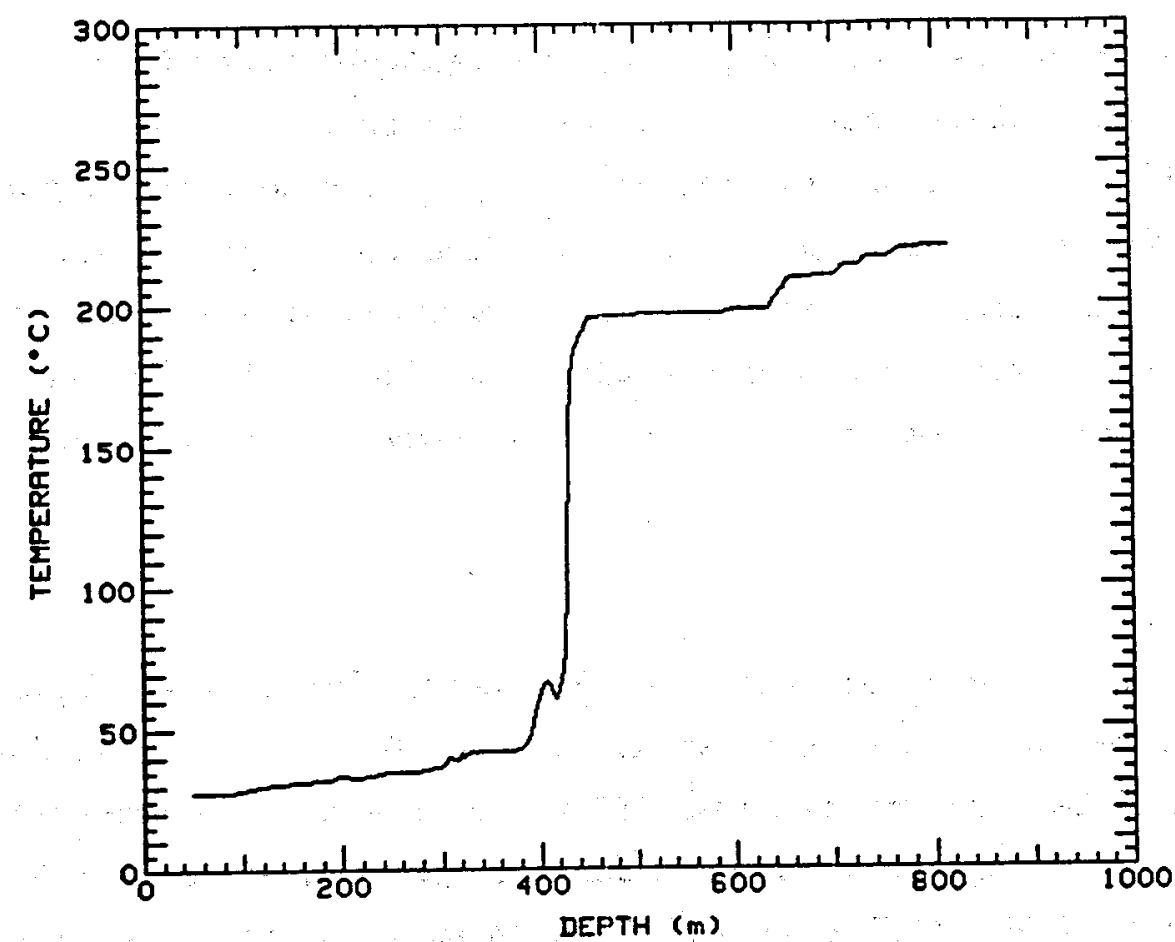

Fig. 13. STP temperature survey, AH-20.

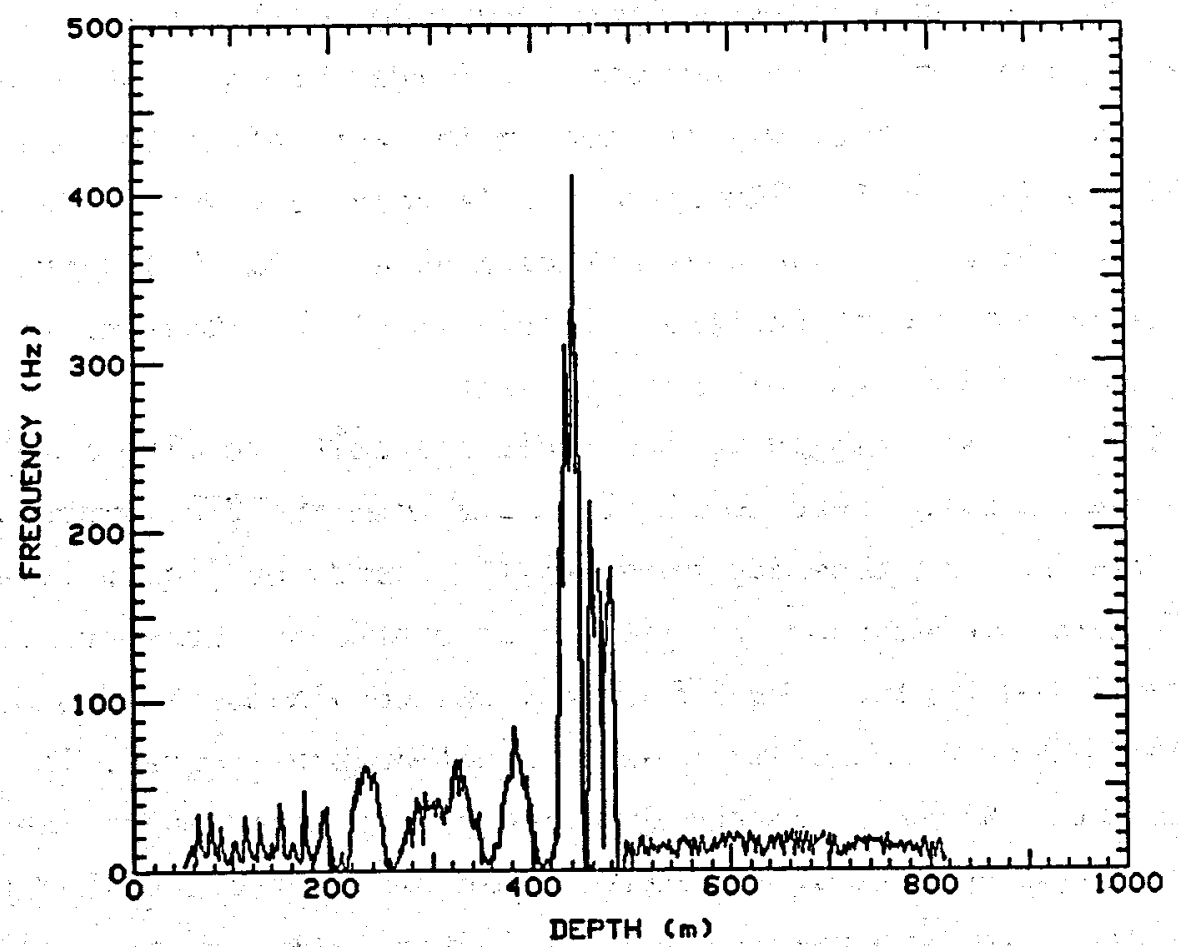

Fig. 14. STP spinner survey, AH-20. 
The three-arm caliper tool (Fig. A-5) was deployed from the surface to a depth of $800 \mathrm{~m}$ (Fig. 15). There is evidence of material build-up in the liner below $700 \mathrm{~m}$ (which may account for the bottoming of the temperature/rabbit tool at $826 \mathrm{~m}$ ) and some evidence of build-up around the lower part of the casing. This build-up may be caused by accumulation of deteriorated cement. There are no indications of a break in either the casing string or the slotted liner. Apparently the fluid is leaving near the casing shoe, which could indicate a bad cement zone.

\section{$\underline{\mathrm{AH}-18}$}

AH-18 is one of the deeper wells in the field. The main production zone was reported to be at $900 \mathrm{~m}$ with a secondary zone $800 \mathrm{~m}$ from the surface. The liquid-to-vapor interface was given as $775 \mathrm{~m}$, and the maximum temperature measured was $244^{\circ} \mathrm{C}$. This well was considered a nonproducer, but it had a high gas pressure of $2.07 \mathrm{MPa}$ (300 psi), which would build up at the wellhead. Reportedly a Kuster temperature tool and about $300 \mathrm{~m}$ of slickline had been left in this well.

Wellhead pressure was measured before inserting the temperature/rabbit tool in the well. The Hesi gauge indicated $2.41 \mathrm{MPa}$ (350 psi) when the well vent line was opened. The tool was started in the well after the pressure dropped to $2.07 \mathrm{MPa}$ (300 psi). Temperature data were recorded while logging both in and out of the well. The tool set down at a depth of $1247 \mathrm{~m}$. The data shown in Fig. 16 do not clearly define a liquid level, but they do indicate a moving boiling zone as the gas continues to vent.

When the STP tool was rigged up, the well was still venting some gas, but the well lhead pressure gauge read zero. The data from the STP temperature probe (Fig. 17) show the boiling zone beginning at $412 \mathrm{~m}$ and the liquid level at $720 \mathrm{~m}$. The STP pressure measurement and the saturated pressure curve (Fig. 18) intersect at the 720-m depth. The STP survey was continued to $1230 \mathrm{~m}$. As we began taking the STP tool out of this well, a noticeable increase in the cable weight was recorded. At first we thought that one or more centralizers had broken and were dragging against the casing. Actually, the tool had become entangled with the slickline previously left in the well. As the wellhead pressure was now ambient, the pressure lock was removed with the well open, and the $300 \mathrm{~m}$ of abandoned slickline was retrieved. 


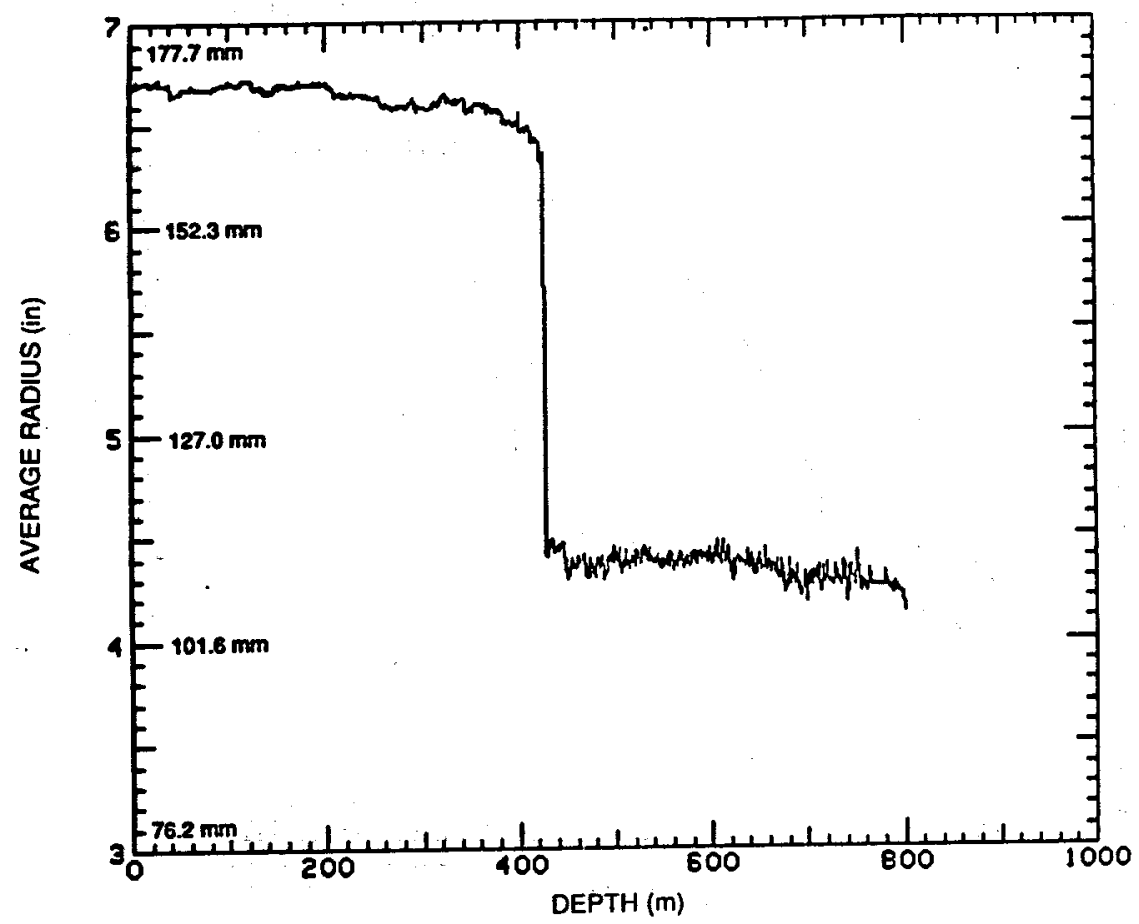

Fig. 15. Three-arm caliper survey, AH-20.

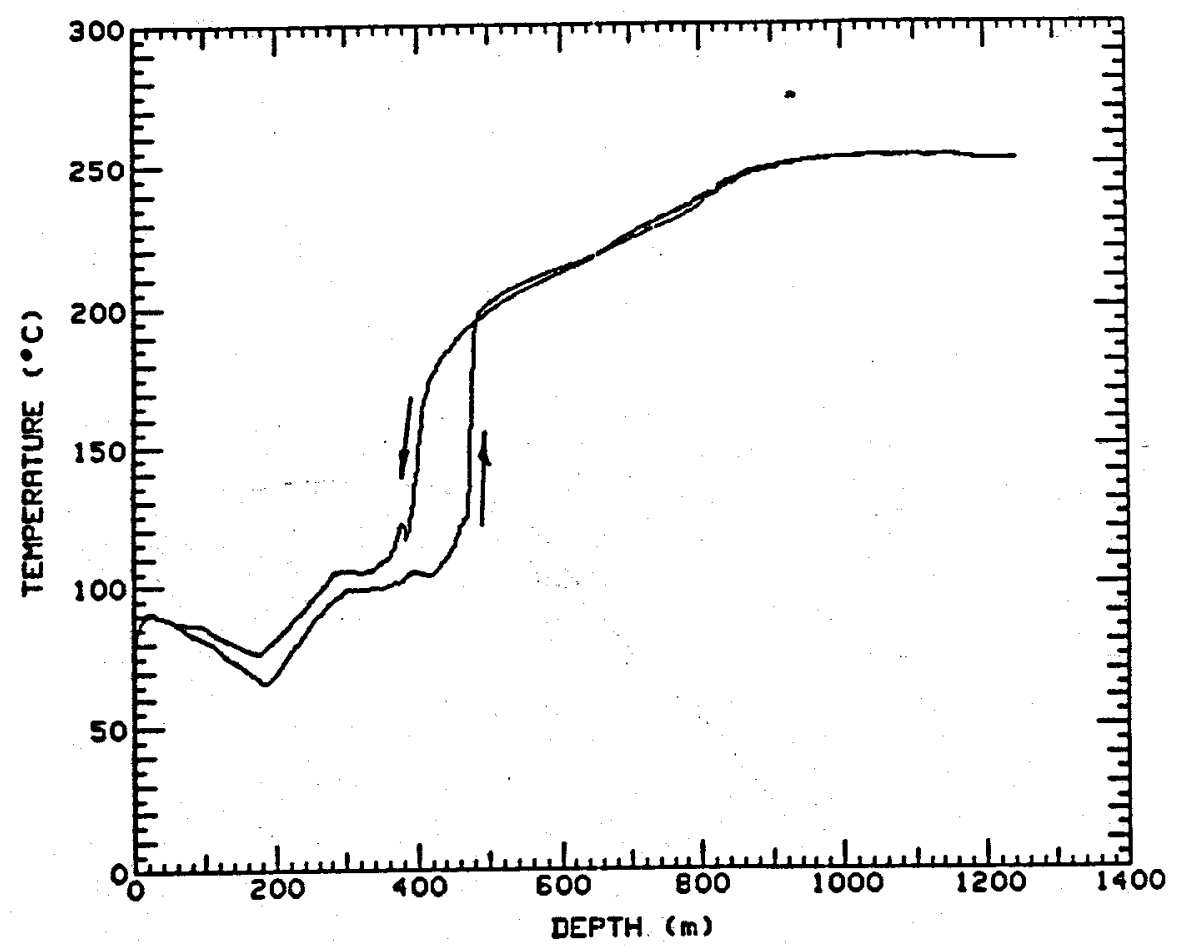

Fig. 16. Temperature/rabbit survey, AH-18. 


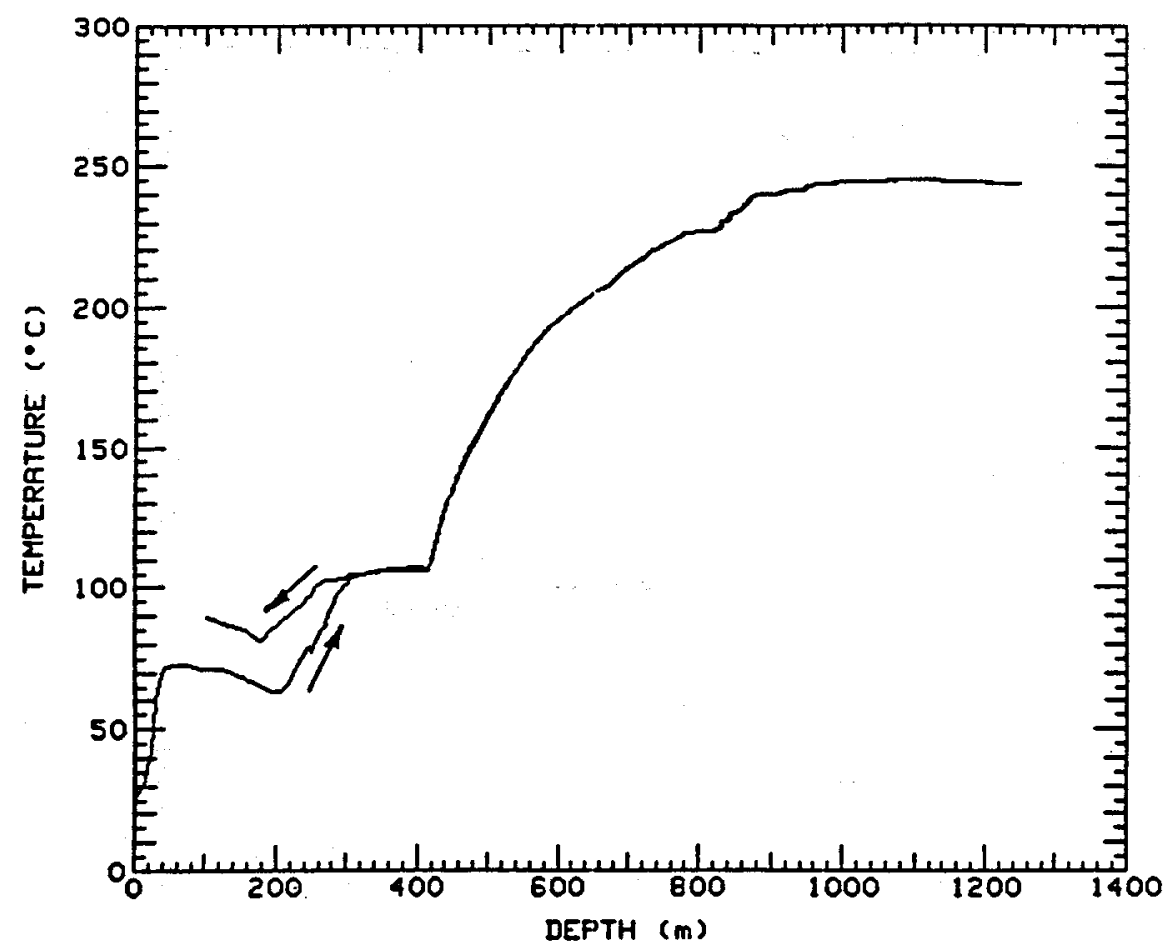

Fig. 17. STP temperature survey, AH-18.

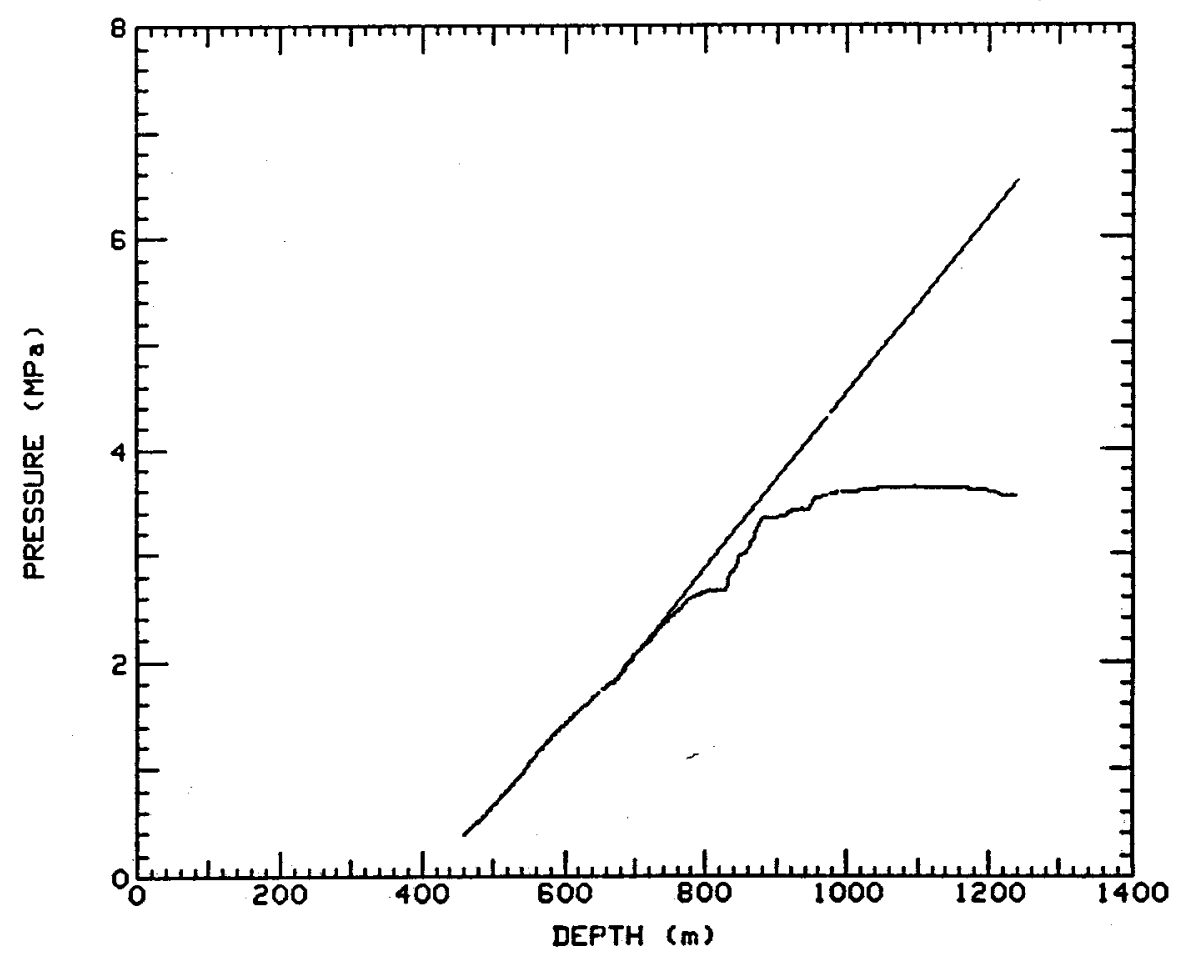

Fig. 18. STP pressure survey, AH-18. 
The three-arm caliper was then deployed to a depth of $1000 \mathrm{~m}$, and a log run was completed to the surface. The top of the liner was detected at $615 \mathrm{~m}$ (Fig. 19). There was no evidence of chemical build-up.

A fluid sample was obtained at $1100 \mathrm{~m}$ and at $750 \mathrm{~m}$ in AH-18.

The first phase of the well logging operations in Ahuachapan was now complete. A total of 18 logs had been run in the four geothermal wells; no cablehead problems had occurred throughout these operations." The second field operation would require some modifications, including a redesign of the spinner impellers and a readjustment of the three-arm caliper. One problem that occurred during the Phase I work was an electric short that developed in the number 2 conductor of the 7-conductor armored cable. The short, which occurred in the lay winding on the drum, could not be repaired on-site. The three-arm caliper uses all seven conductors to ensure electrical isolation from the readout potentiometers and the dc motor voltage. After the short occurred it was necessary to tie the signal common to the cable armor, which was also the motor voltage return. This wiring arrangement induced motor noise into the signal lines, but it allowed the logging operations to be completed. The cable and drum were removed from the truck after completing Phase I work and shipped to New Orleans, where equipment was available to repair and spool the cable properly.

\section{B. Phase II}

Phase II of the Ahuachapán logging operations was conducted in April 1988. An additional four wells were surveyed during this phase: AH-16, -19, -22 , and -32. AH-16 was a nonproducing well located in the southern part of the field between $A H-27$ and $A H-32$, both of which were good production wells. $A H-19$ and AH-22 were located near the center of the field, and AH-32 was in the southern part of the exploitation area. The completion schedule for the four wells is given in Table II.

Before the Phase II wells were logged, the mechanical breaks on the draw works were adjusted to allow better logging rate control. New impellers in the STP tool were designed to measure flow rates up to $70 \mathrm{~kg} / \mathrm{s}$. The armored cable was repaired, which eliminated the short in the number 2 conductor. 


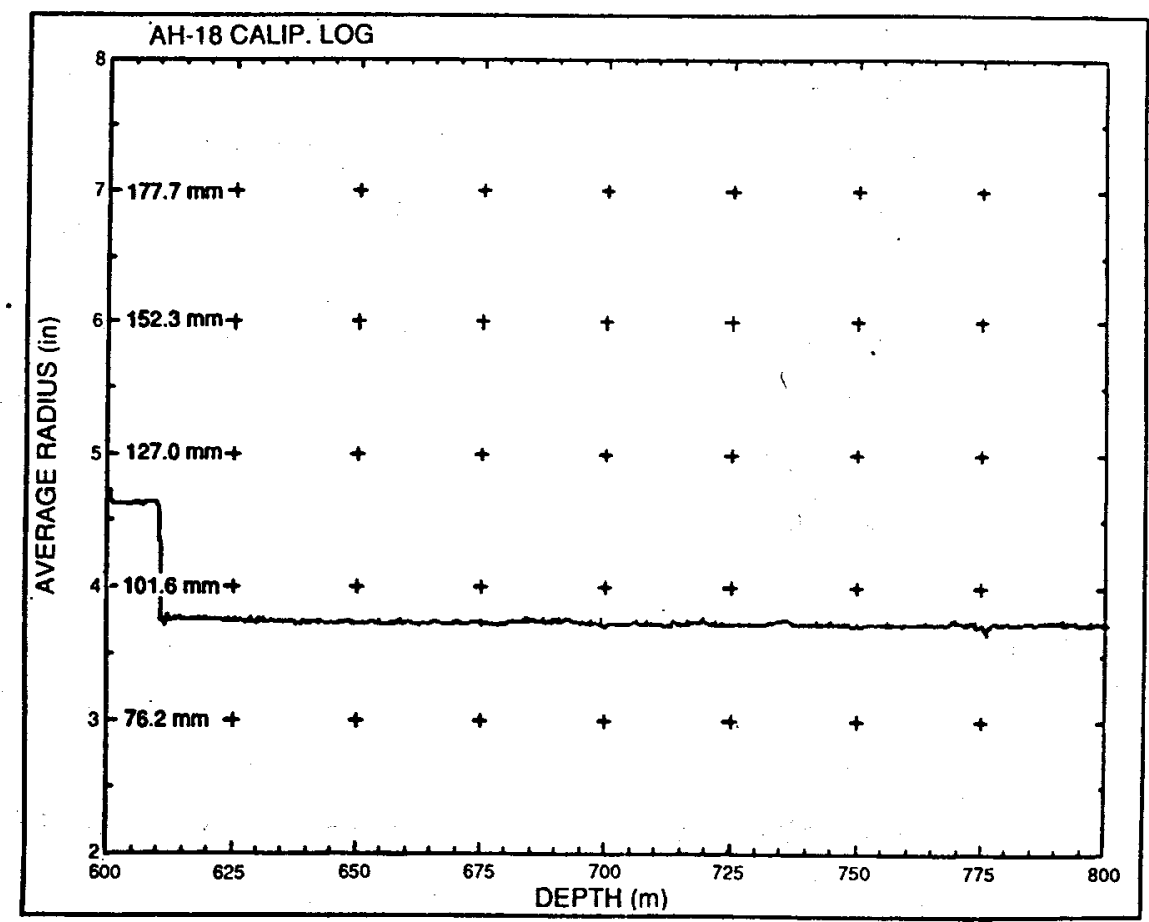

Fig. 19. Three-arm caliper survey, AH-18.

TABLE II. COMPLETION SCHEDULE, PHASE II

Well Number

\begin{tabular}{|c|c|c|c|c|}
\hline & $\mathrm{AH}-16$ & $\mathrm{AH}-19$ & $\mathrm{AH}-22$ & $\mathrm{AH}-32$ \\
\hline Casing diameter, mm & 338.5 & 244.5 & 244.5 & 244.5 \\
\hline Liner diameter, mm & 244.5 & 193.7 & none & 193.7 \\
\hline Openhole diameter, $\mathrm{mm}$ & 311.5 & 215.9 & 222.2 & 215.9 \\
\hline Bottom of casing, m depth & 750 & 676 & 510 & 490 \\
\hline Top of liner, in depth & & $655^{\star}$ & & 470 \\
\hline Bottom of liner, in depth & 1006 & 1009 & & 1500 \\
\hline Bottom of hole, in depth & 1006 & 1415 & 659 & 1504 \\
\hline
\end{tabular}

"The liner in AH-19 is not slotted. 
$\underline{\mathrm{AH}-32}$

AH-32 was a good production well with a reported mass flow rate of $70 \mathrm{~kg} / \mathrm{s}$. Maximum temperature was $241^{\circ} \mathrm{C}$, and the shut-in well lhead pressure was 1.1 MPa (160 psi). There were several production zones with locations estimated at 775 (two-phase flow), 800, 1000, and $1400 \mathrm{~m}$. The major production zones were reported to be at the 1000- and 1400-m depth.

The first temperature log was started in the well under:flowing conditions. The temperature/rabbit tool was lowered in the casing to $50 \mathrm{~m}$ and then stopped while the well flowline was opened to allow a flow rate of approximately $45 \mathrm{~kg} / \mathrm{s}$. The tool was then run in the well until a set-down at $470 \mathrm{~m}$ stopped the tool. The tool would not enter the slotted liner under the flow conditions, and the well had to be shut in. The temperature log was run to a depth of $1450 \mathrm{~m}$ under static conditions and back up the hole to the surface. No obstructions were encountered in AH-32 other than the top of the liner. Maximum temperature measured was $241^{\circ} \mathrm{C}$. The three-arm caliper tool was run in AH-32 under shut-in (static) flow conditions. The arms were deployed at $1400 \mathrm{~m}$, and the caliper survey was completed to the surface. The top of the liner was tagged at $465 \mathrm{~m}$. The data showed no evidence of chemical build-up in the well (Fig. 20).

Difficulties were encountered when running the STP tool in AH-32. The higher pressure at the wellhead at an initial flow rate of $45 \mathrm{~kg} / \mathrm{s}$ and the light weight of the tool [36.3 $\mathrm{kg}(80 \mathrm{lb})]$ prevented the tool from entering the well. The tool, therefore, was deployed to a depth of $200 \mathrm{~m}$ with the well shut in. The well was again opened to a flow rate of $45 \mathrm{~kg} / \mathrm{s}$, and the tool descended to $470 \mathrm{~m}$, where it would not enter the slotted liner. The flow rate was then decreased to $20 \mathrm{~kg} / \mathrm{s}$, and the STP $\log$ run was successfully completed from 480 to $1450 \mathrm{~m}$ at this lower flow rate.

The liquid-to-vapor interface was measured at $840 \mathrm{~m}$ as shown by the STP temperature data (Fig. 21) and the measured pressure and saturation pressure calculated at temperature (Fig. 22). The measured pressures above the liquid surface are lower than the saturation pressures, which indicates the vapor was in the superheated region. If we use the pressure and temperature data and assume no heat loss in the two-phase region, the calculated vapor quality for the $20 \mathrm{~kg} / \mathrm{s}$ flow rate is shown in Fig. 23 . 


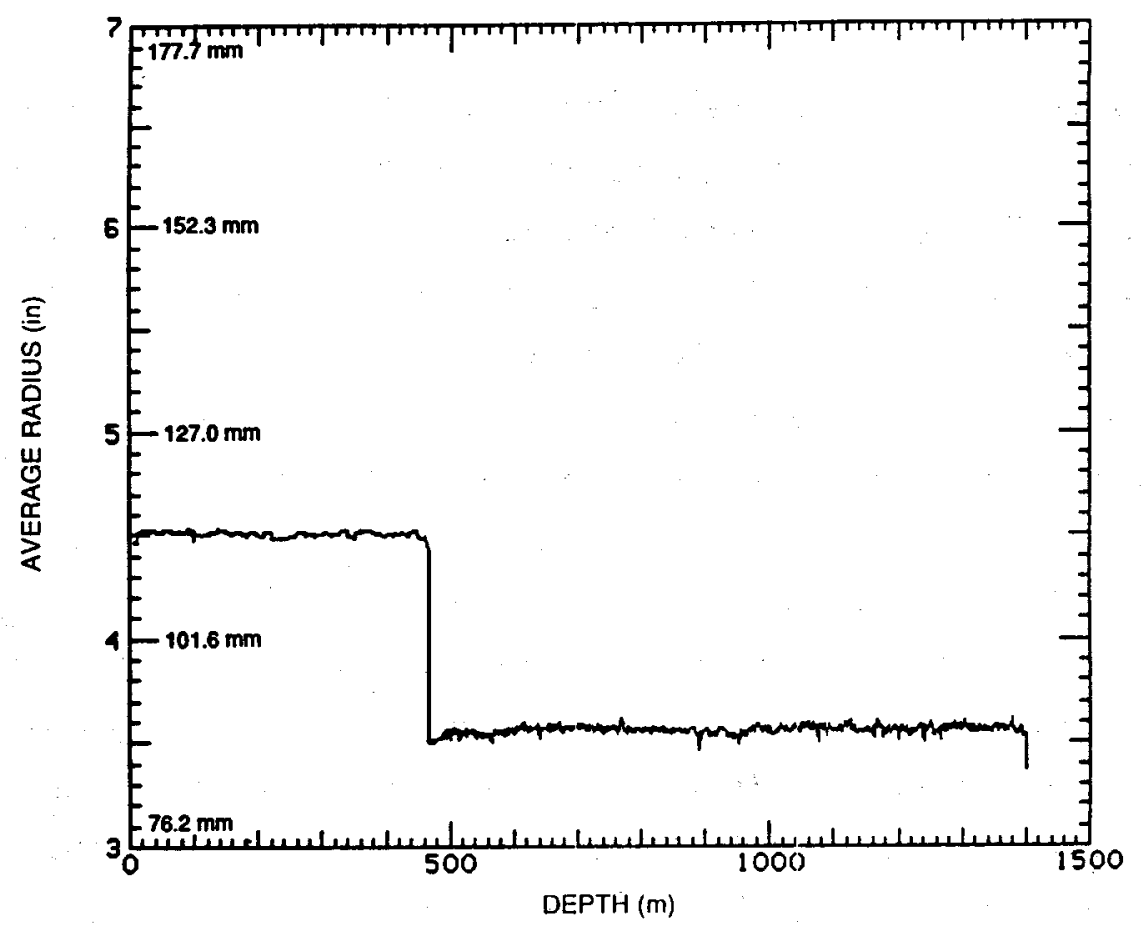

Fig. 20. Three-arm caliper survey, AH-32.

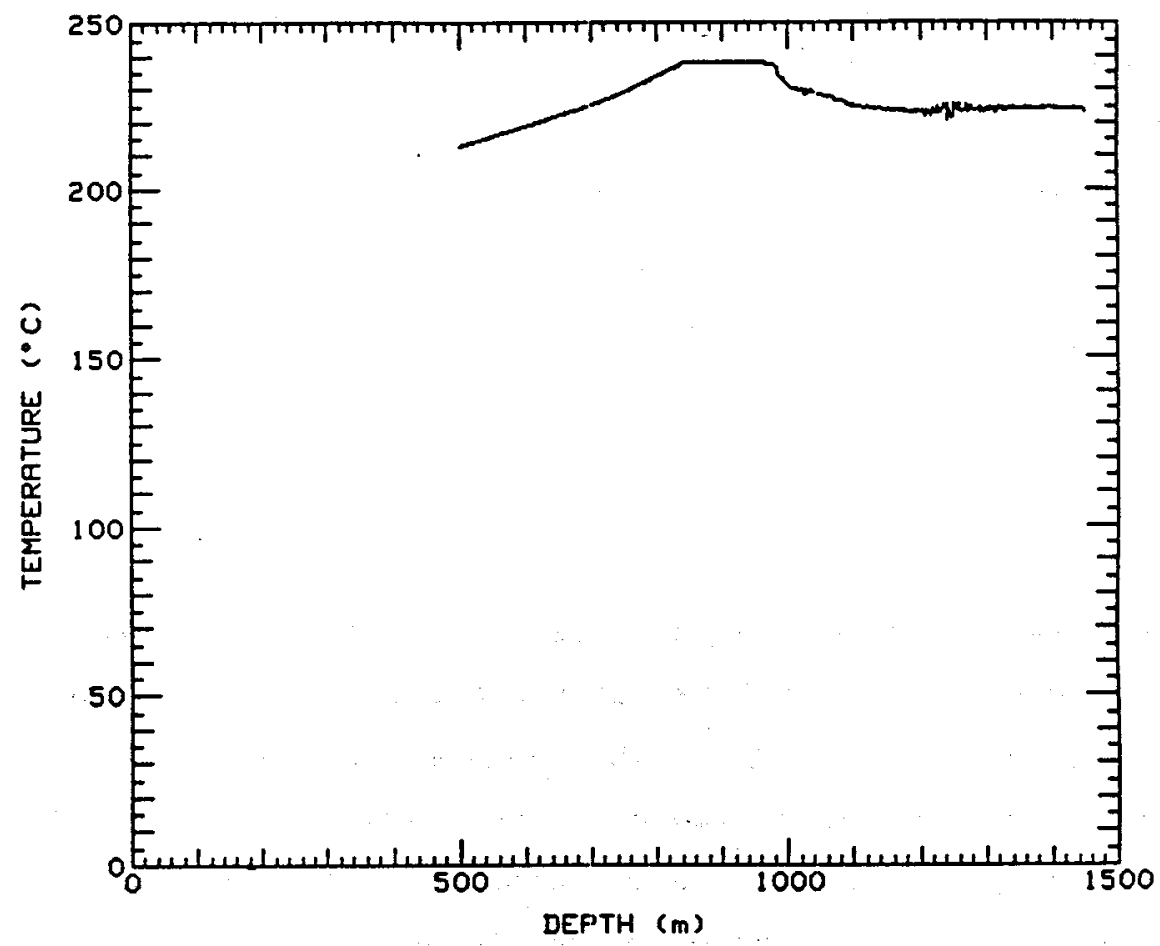

Fig. 21. STP temperature survey $(20 \mathrm{~kg} / \mathrm{s}), \mathrm{AH}-32$. 


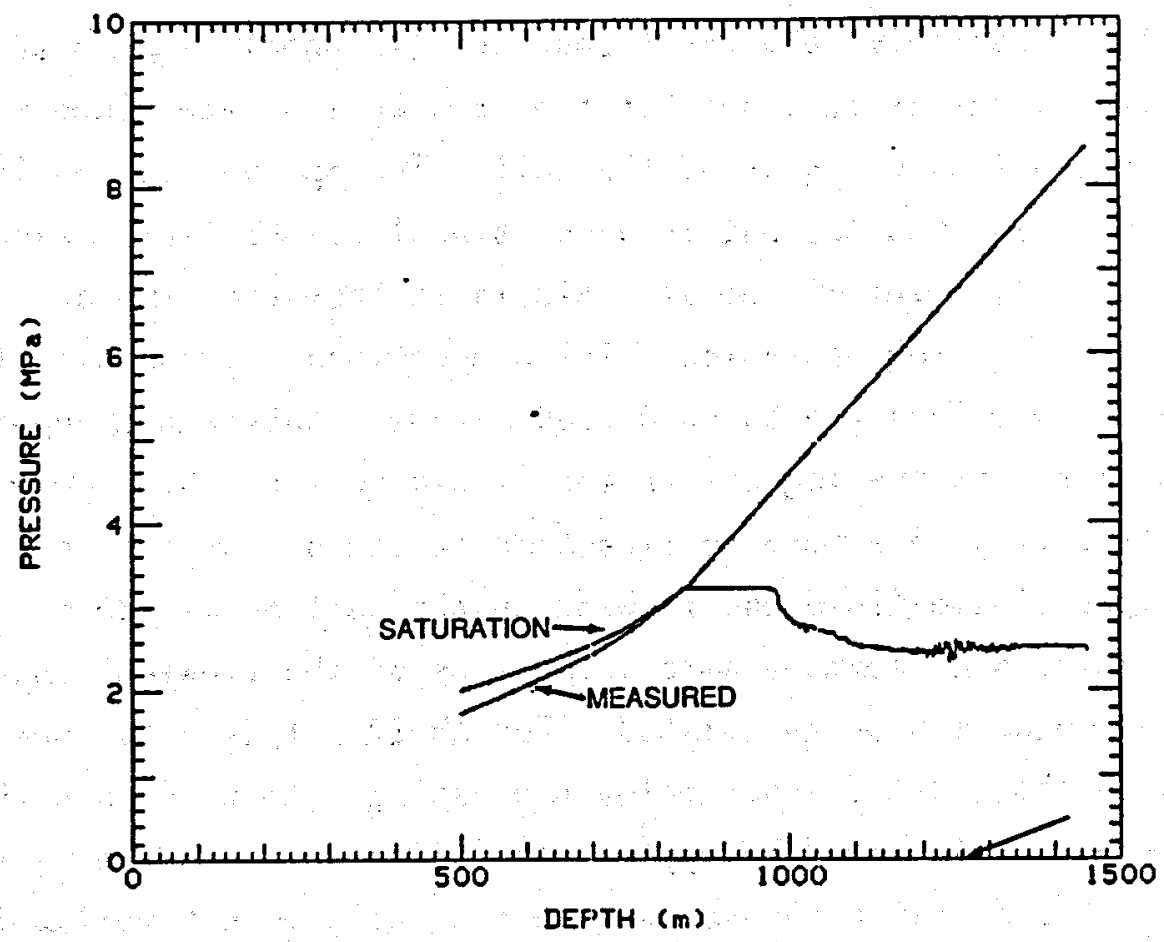

Fig. 22. Measured and saturation pressures $(20 \mathrm{~kg} / \mathrm{s}), \mathrm{AH}-32$.

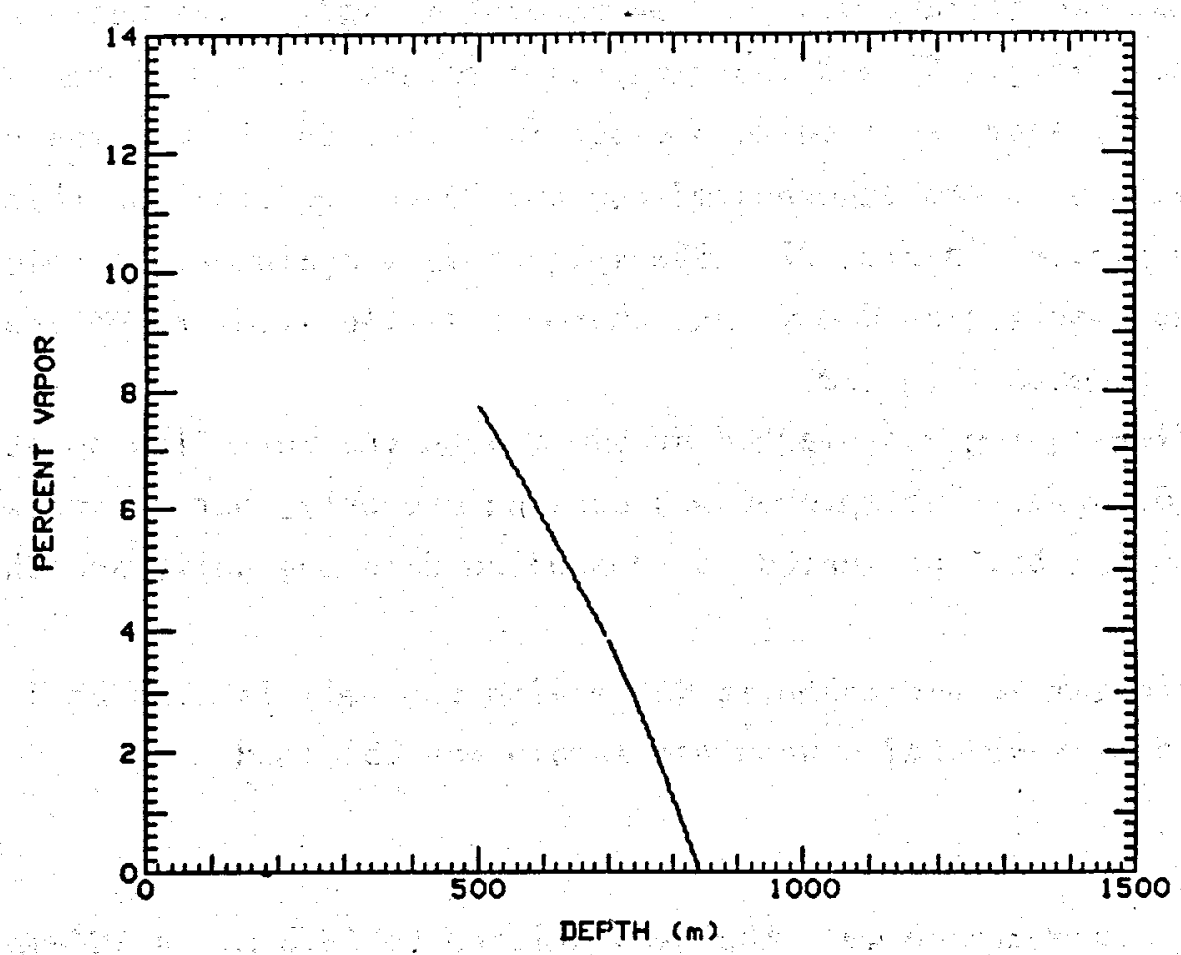

Fig. 23. Vapor quality $(20 \mathrm{~kg} / \mathrm{s}), A H-32$. 
The output of the fluid velocity transducer (spinner) is plotted in Fig. 24. A proportionality constant for the spinner was determined from the data obtained in the liquid region of the well. The spinner output in hertz for both the log-in and the log-out is proportional to the fluid velocity plus the tool velocity. Tool velocities are calculated from the time and depth data recorded during the logging operation. The proportionality constant for the spinner in AH-32 was calculated to be $0.0739 \mathrm{~m} / \mathrm{s} / \mathrm{Hz}$. Notice the negative frequency counted during the log out in the liquid region, which means that the impellers were rotating in a reverse direction coming out of the hole and confirms that very little fluid was flowing up the well below $980 \mathrm{~m}$.

When velocities and thermodynamic properties of the flowing fluid are known, mass flow rates can be calculated. For AH-32 all data for the flowing log were taken in the slotted liner below the casing. In this case the diameter of the open hole would be applicable for calculating the mass flow rate, but since this diameter throughout the open hole is not well defined, the calculated mass flow rates are quite erratic. Using a constant 216-mm (8.5-in.) diameter for the open hole was not a good assumption. A second STP $\log$ was run from 500 to $1200 \mathrm{~m}$ at a flow rate of $45 \mathrm{~kg} / \mathrm{s}$. The data from the temperature probe (Fig. 25) and the measured pressure and calculated saturation pressure (Fig. 26) show the liquid-to-vapor interface at $860 \mathrm{~m}$. The vapor above this depth is in the superheated region. Vapor quality for this second flowing $\log$ is plotted in Fig. 27. The spinner data again show a major production zone starting at $980 \mathrm{~m}$, but there is little evidence of production zones below this depth (Fig. 28).

A third flowing $\log$ was started at $500 \mathrm{~m}$ with the well flowing at approximately $60 \mathrm{~kg} / \mathrm{s}$. The spinner was working properly, but two broken centralizers on the tool prevented it from going down the well, and the log was terminated.

A 4- $\ell$ fluid sample was taken at $950 \mathrm{~m}$ with the well flowing at $70 \mathrm{~kg} / \mathrm{s}$. The temperature measured $238^{\circ} \mathrm{C}$ when the sample was obtained.

$\underline{\mathrm{AH}-19}$

AH-19 was a production well that was drilled to $1415 \mathrm{~m}$. A 194-mm-diameter (7-5/8-in.) unslotted liner was hung in the casing at $655 \mathrm{~m}$. The bottom of the 


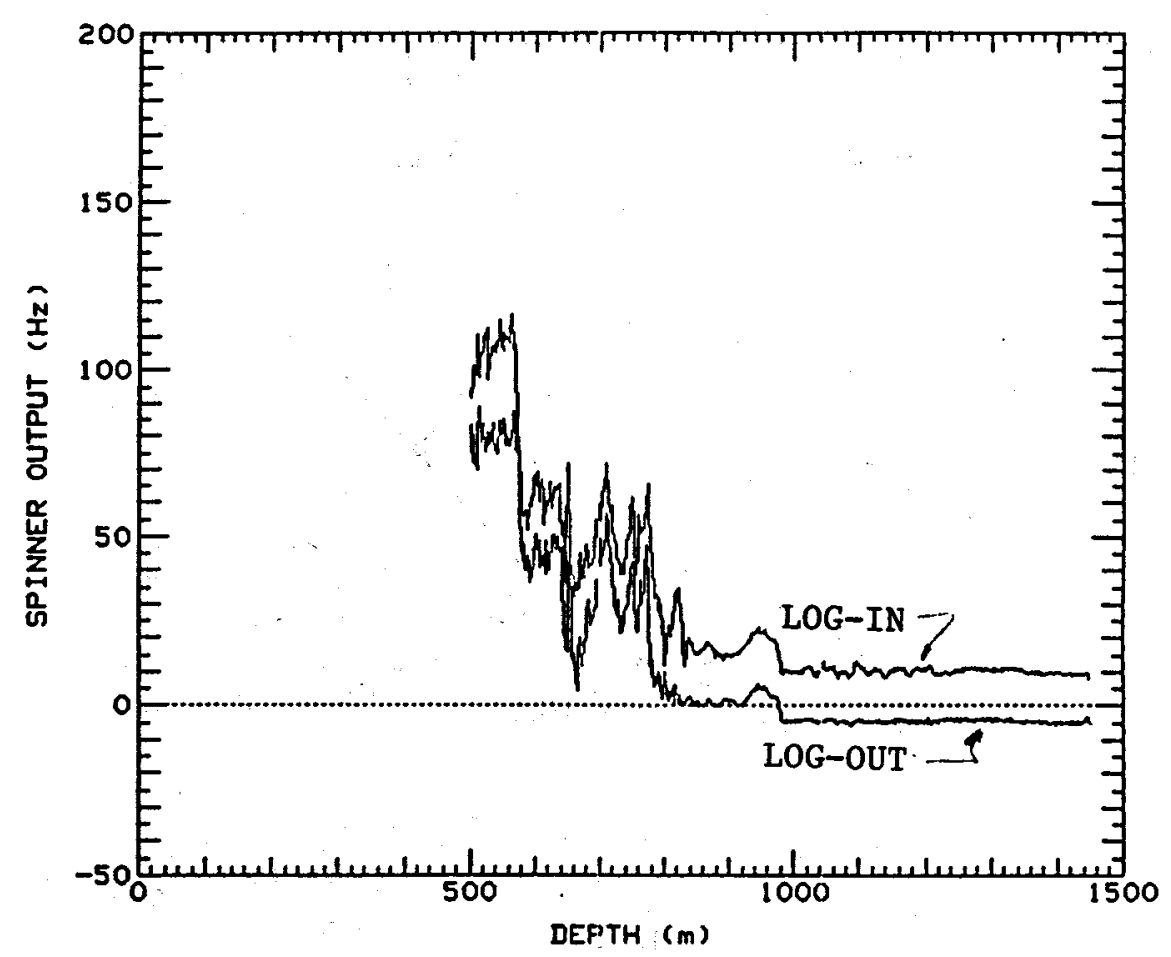

Fig. 24. STP spinner survey $(20 \mathrm{~kg} / \mathrm{s}), A H-32$.

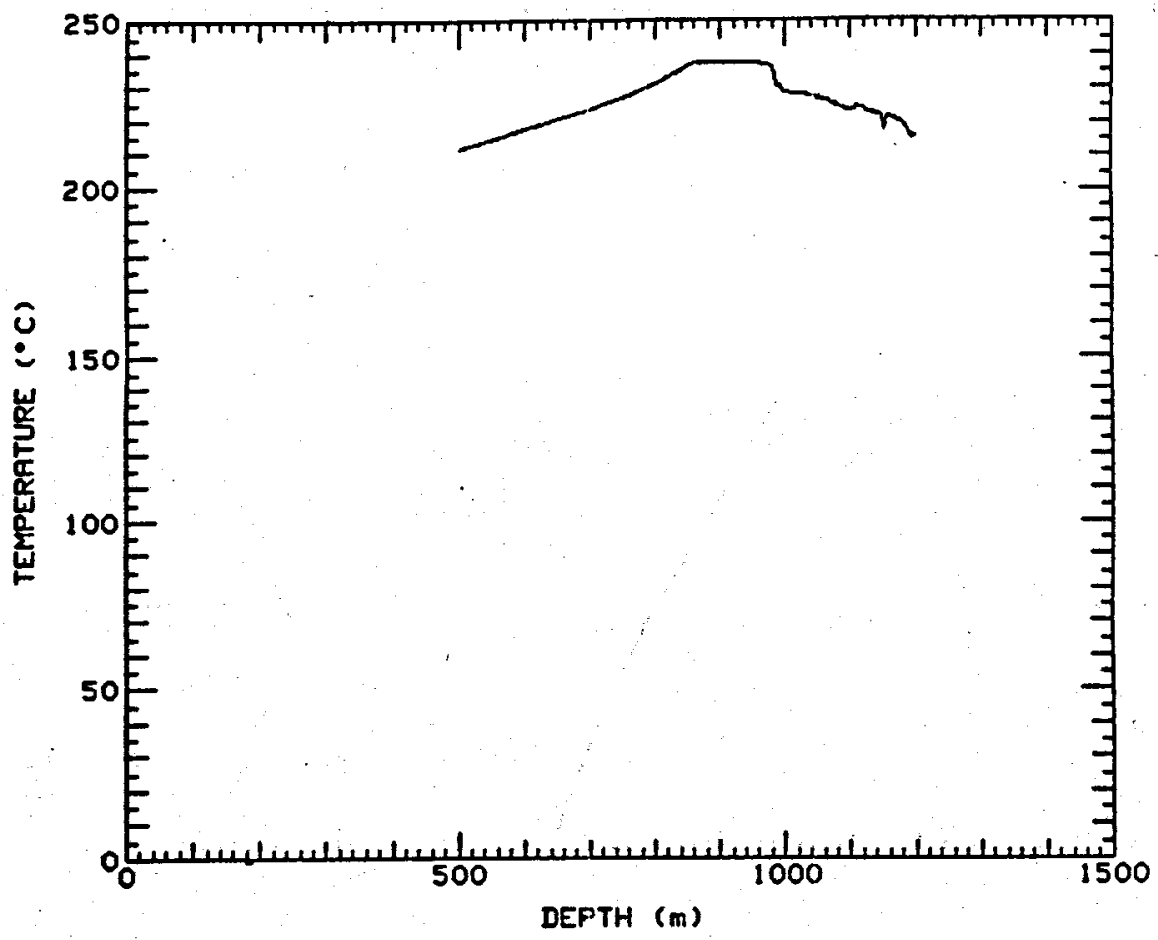

Fig. 25. STP temperature survey $(45 \mathrm{~kg} / \mathrm{s}), A H-32$. 


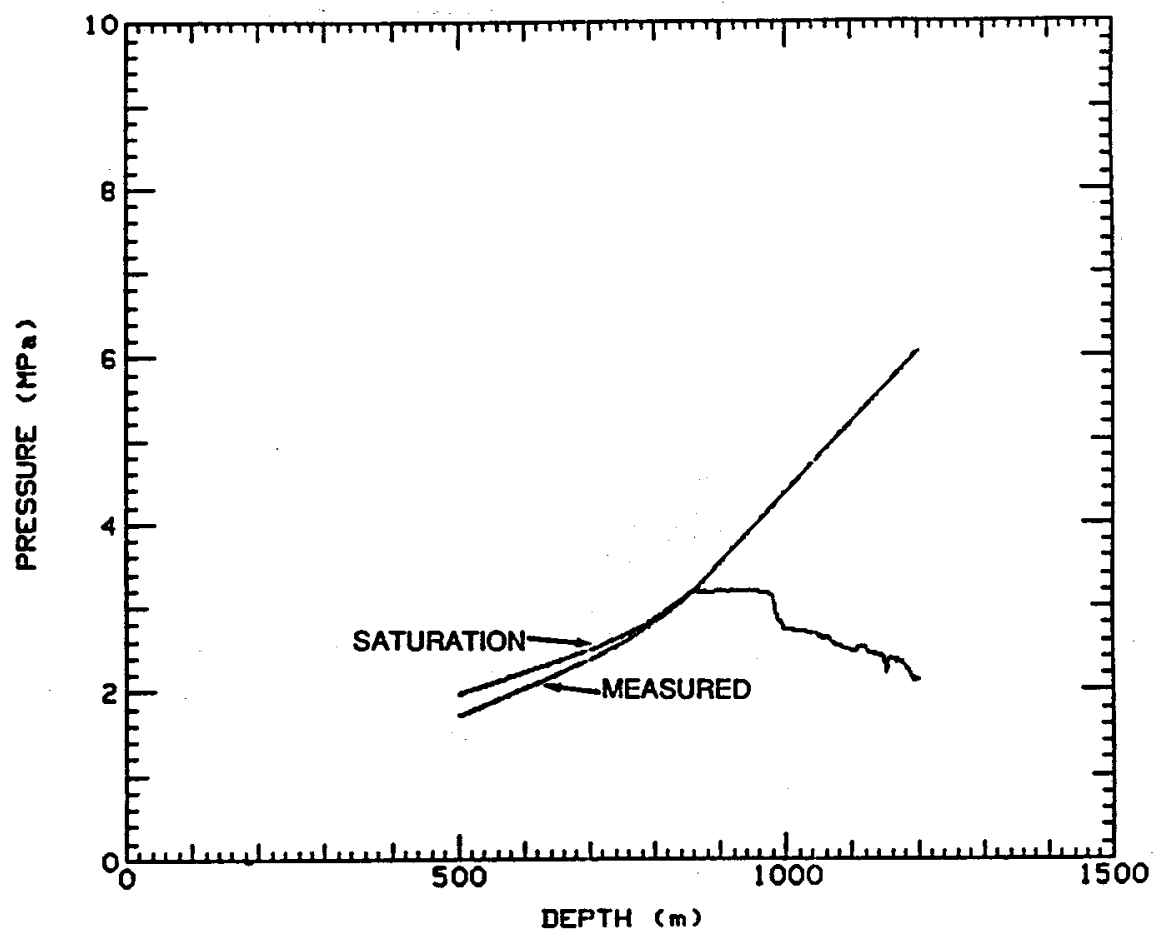

Fig. 26. Measured and saturation pressures $(45 \mathrm{~kg} / \mathrm{s}), \mathrm{AH}-32$.

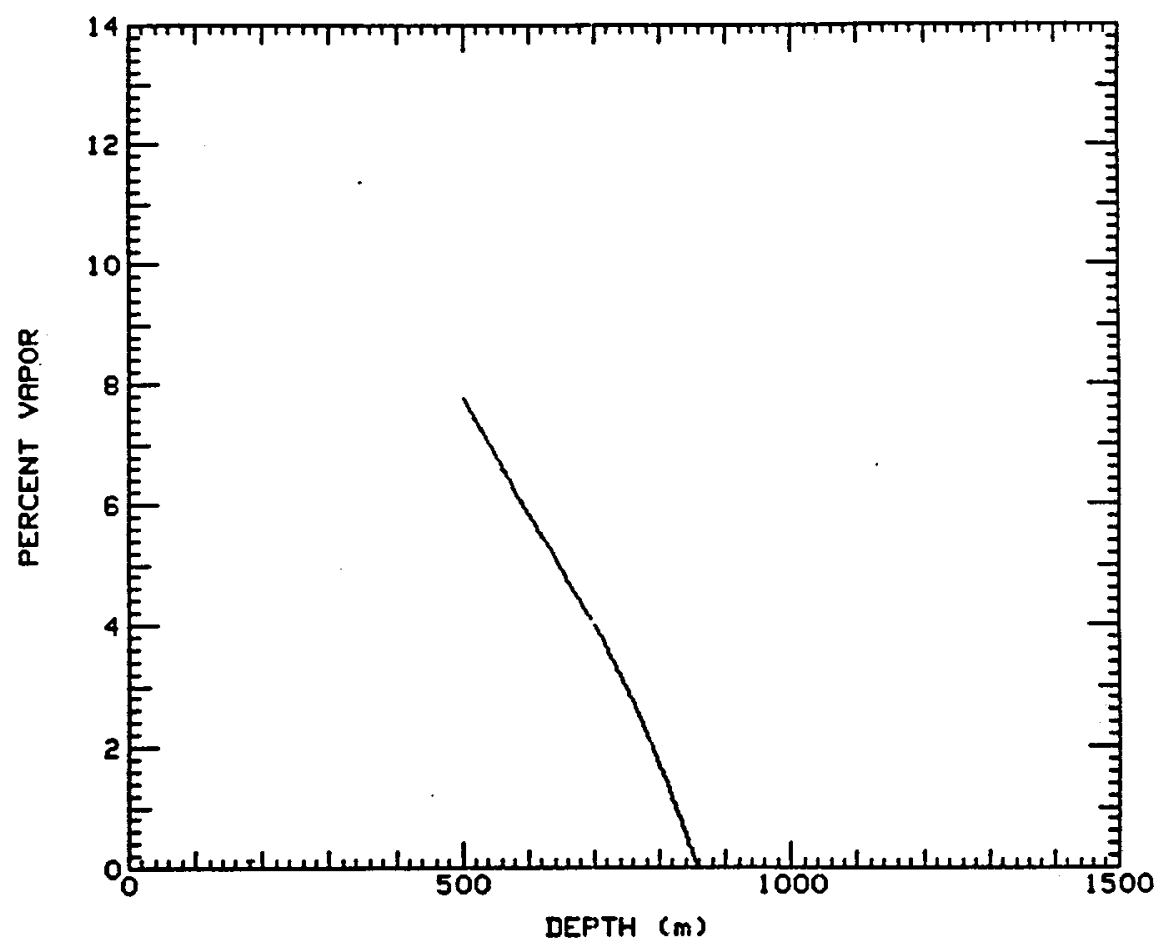

Fig. 27. Vapor quality $(45 \mathrm{~kg} / \mathrm{s}), \mathrm{AH}-32$. 


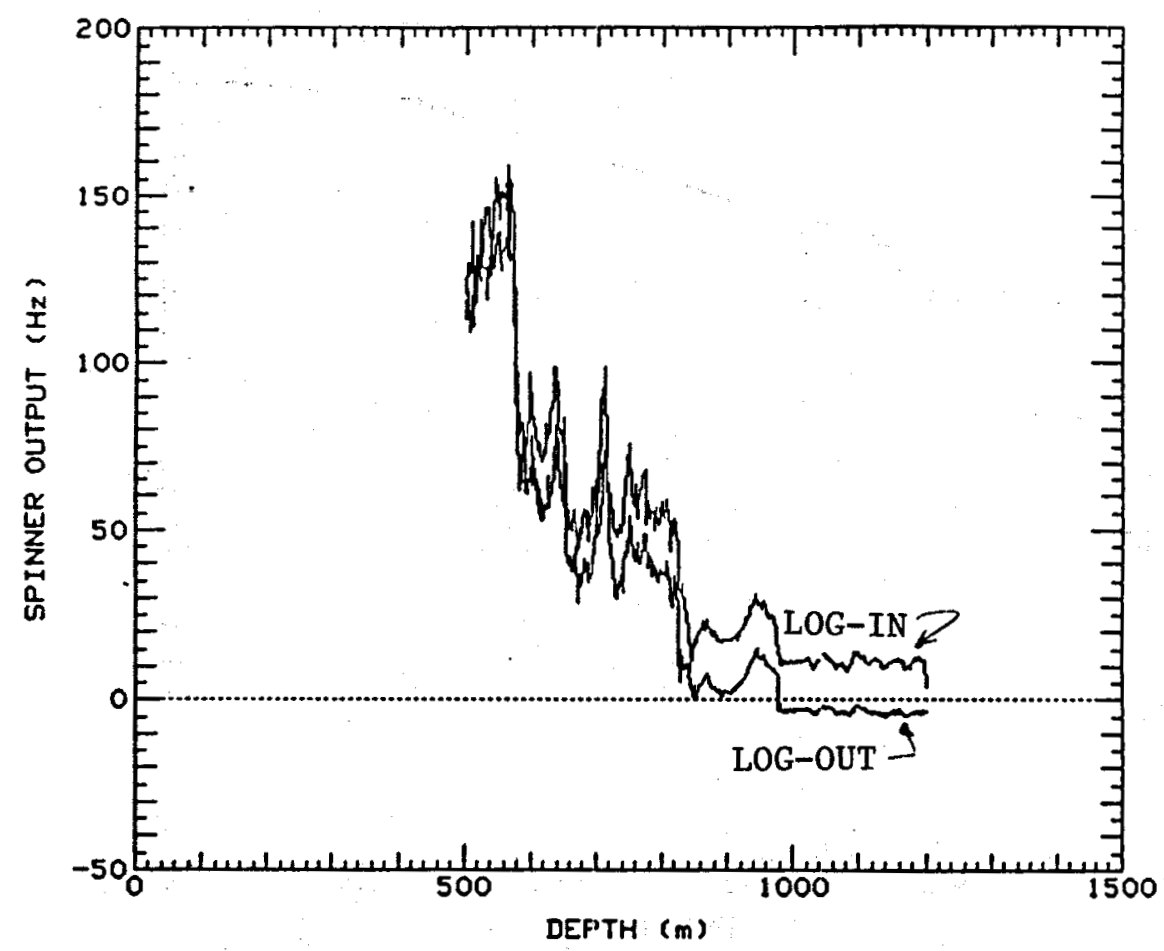

Fig. 28. STP spinner survey $(45 \mathrm{~kg} / \mathrm{s}), A H-32$.

liner reached $1009 \mathrm{~m}$. The mass flow characteristics were well defined at $65.3 \mathrm{~kg} / \mathrm{s}$. The liquid level was reported as $633 \mathrm{~m}$, and the well head shut-in pressure was reported to be $2.66 \mathrm{MPa}$ (386 psi). Our primary purpose in this well was to obtain a three-arm caliper survey.

The temperature/rabbit survey was started in the well with the well open to flow. The flow valve was opened just before the survey began. The temperature fluctuations while logging in the well are due to initial flowing conditions before a steady-state condition was reached. The data plotted while logging out of the well show the stabilized temperatures (Fig. 29). The maximum temperature measured was $232^{\circ} \mathrm{C}$.

The caliper log in AH-19 (Fig. 30) shows a very smooth liner with a radius of $91.4 \mathrm{~mm}$ ( $3.6 \mathrm{in}$.$) . The top of the liner was detected at 670 \mathrm{~m}$. The caliper data in the $244-\mathrm{mm}(9-5 / 8-i n$.) casing show a somewhat erratic $117-\mathrm{mm}(4.6-i n)$. radius. The noisy data were probably caused by several tool centralizers that broke when the transition from the liner to the casing was encountered. 


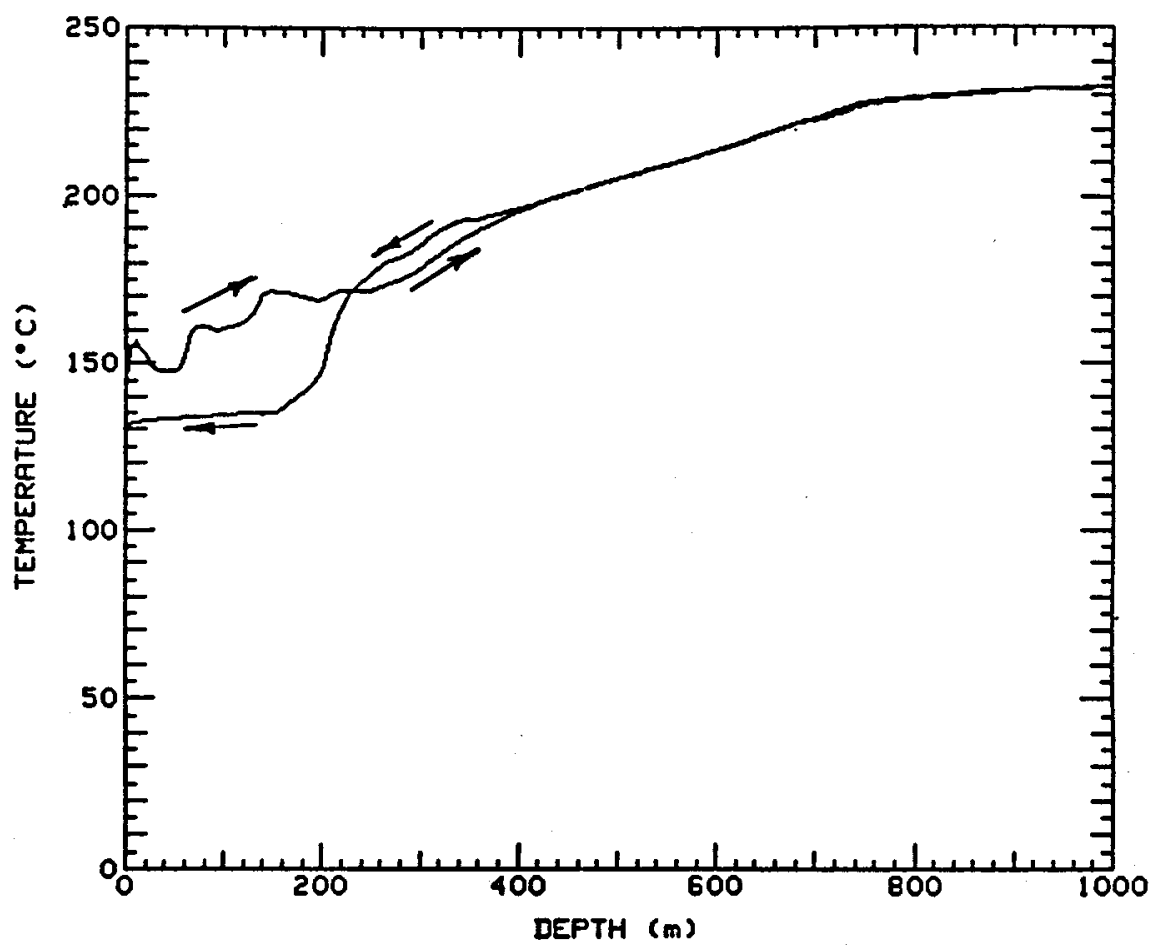

Fig. 29. Temperature/rabbit survey, AH-19.

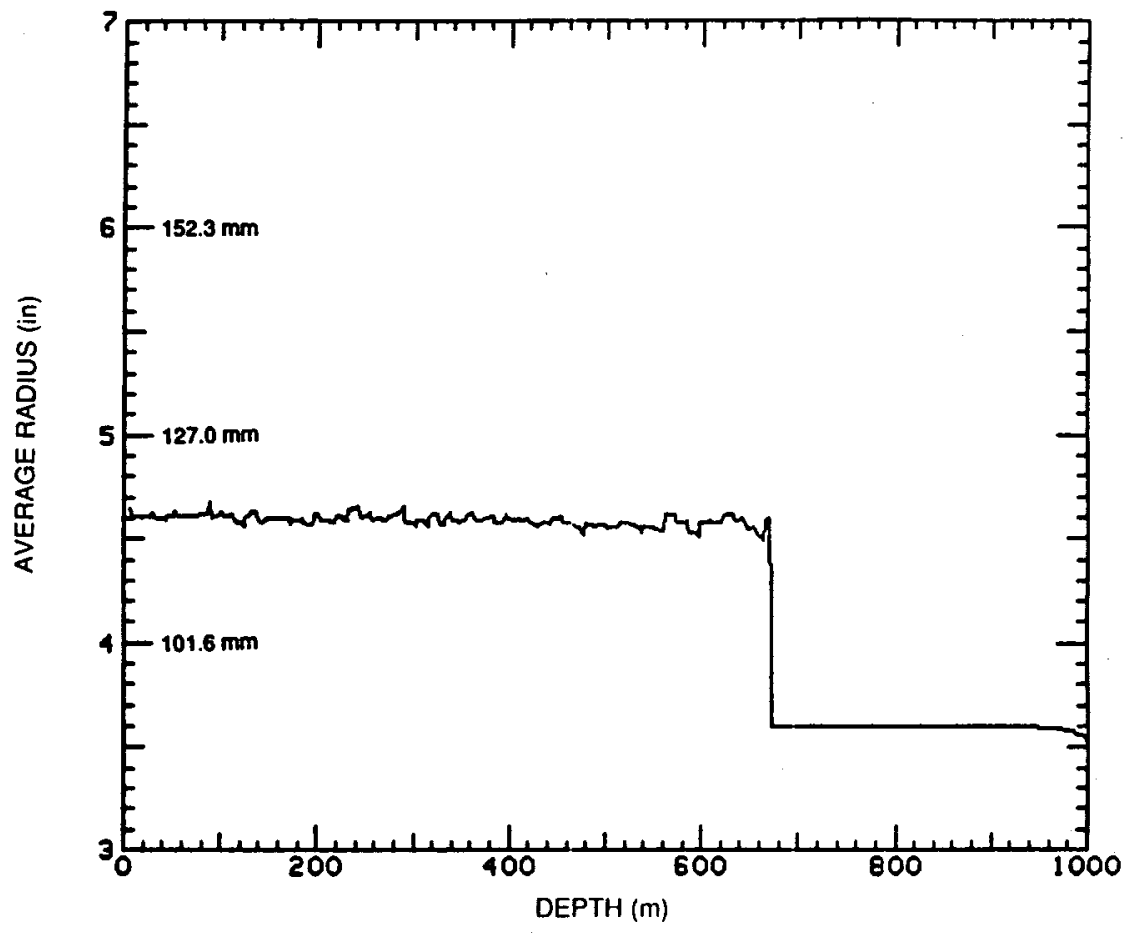

Fig. 30. Three-arm caliper survey, AH-19. 
AH-16

Classified as a nonproducer, $\mathrm{AH}-16$ was a troublesome well. Although the well was not on the original schedule, CEL was interested in obtaining whatever data were possible because the well was located on a line between AH-27 and AH32 , both good production wells. This well had a history of low flow rates but high pressures at the wellhead. The maximum temperature previously measured in the well was $232^{\circ} \mathrm{C}$. The casing schedule was somewhat different than initially reported. The 338-mm (13-3/8-in.) casing extended to $510 \mathrm{~m}$. A section of 273-mm (10-3/4-in.) slotted liner was hung in the casing at $485 \mathrm{~m}$. The bottom of this liner, at a depth of $750 \mathrm{~m}$, was attached to a $244-\mathrm{mm}(9-5 / 8-\mathrm{in}$. slotted liner that extended to $1000 \mathrm{~m}$. Liner slots of various sizes and with rough edges were cut with a torch on site. There was some evidence that this well was dominated by a steam aquifer at about $620 \mathrm{~m}$.

The temperature/rabbit survey was run with the well shut in (Fig. 31). No clear liquid-to-vapor interface is indicated on the figure.

The arms on the three-arm caliper tool stuck, producing an erratic log as shown in Fig. 32. The caliper tool was covered with a gritty tar-like substance when it was retrieved from the well. This material, embedded in the arm mechanisms, caused the arms to stick. The cut slots in the liners were wide enough to allow the arm tips to fall into them, which caused severe wearing of the arm tip mounting brackets.

A fluid sample was obtained at $650 \mathrm{~m}$ with the well flowing at $70 \mathrm{~kg} / \mathrm{s}$. As expected, little liquid was in the sample bottle, but the gritty tar covered the valve and drive mechanism and required a considerable cleaning effort to remove. We decided not to run the STP tool in this well.

\section{$\underline{\mathrm{AH}-22}$}

A shallow well, AH-22 was cased to $510 \mathrm{~m}$ with an open hole from there to $660 \mathrm{~m}$. The water level was reported by CEL to be at $640 \mathrm{~m}$, and the well had a maximum flow rate of $24 \mathrm{~kg} / \mathrm{s}$. The previously measured maximum temperature was $214^{\circ} \mathrm{C}$. Wellhead pressure was quite high when the well was flowing, but measured values were not available. There was speculation that the fluid in this well contained vapor and that there was no liquid interface. 


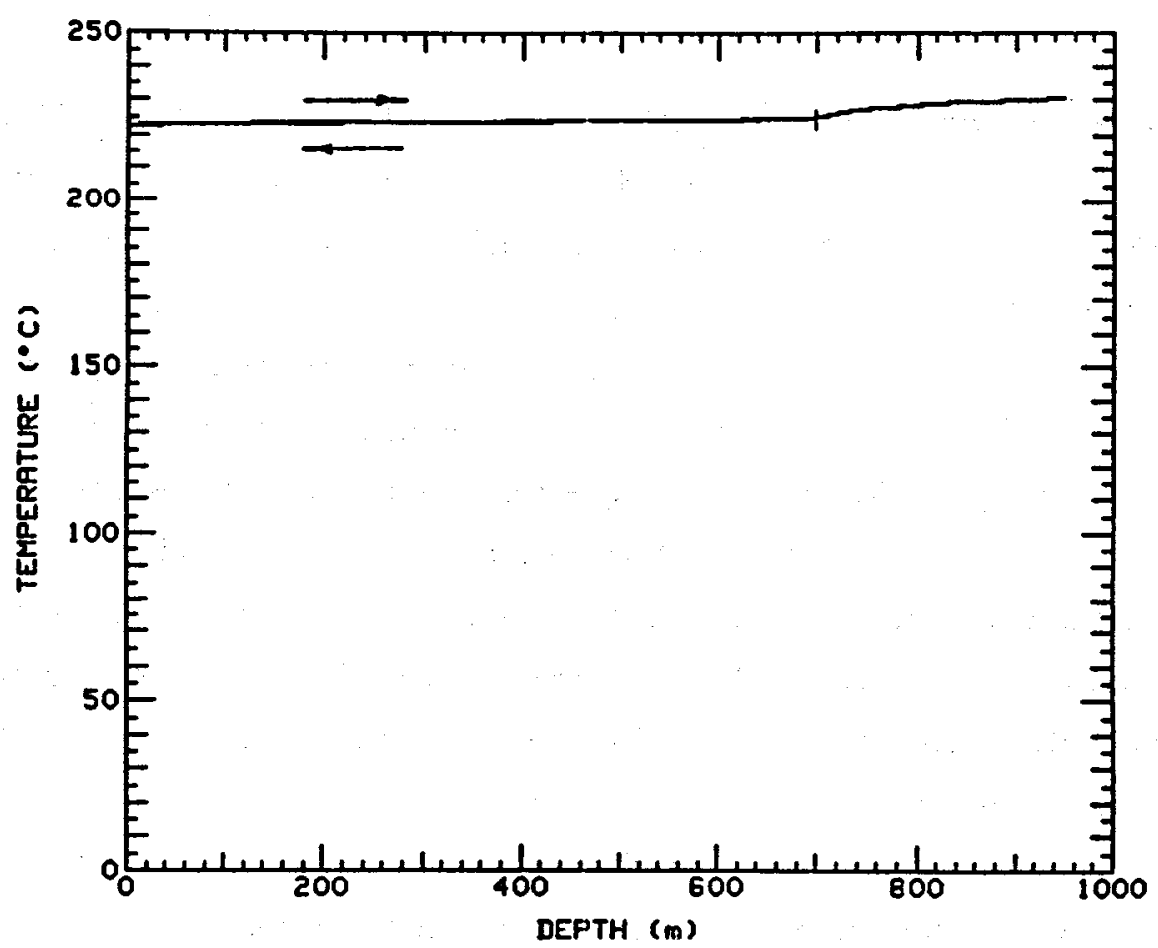

Fig. 31. Temperature/rabbit survey, AH-16.

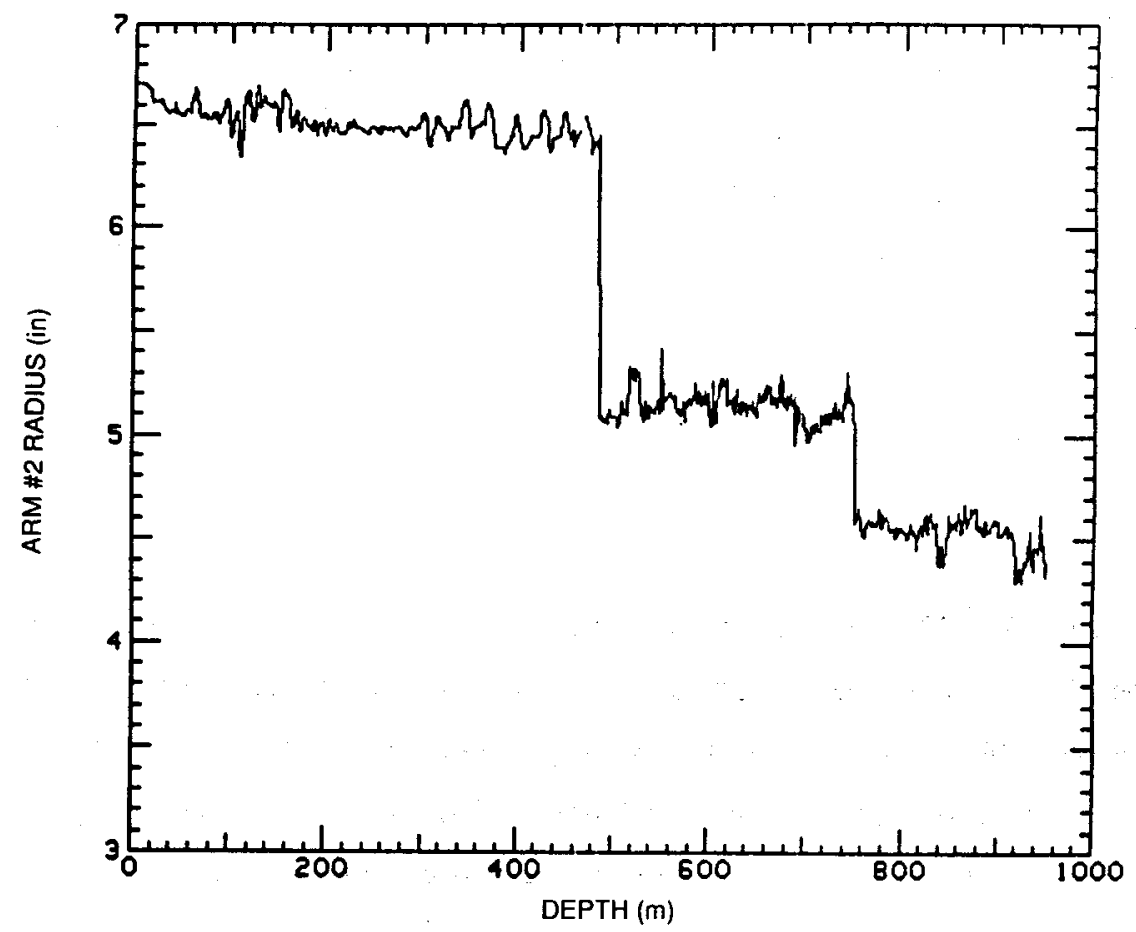

Fig. 32. Three-arm caliper survey, AH-16. 
The temperature/rabbit tool was lowered to $50 \mathrm{~m}$ with the well shut in. When the well was opened to flow, the mass of this tool was not sufficient to allow a controlled logging rate. The well flow was reduced to lower the upward thrust on the logging tool and cable. The temperature probe was then successfully run to $650 \mathrm{~m}$. The well was shut in to obtain the temperature log coming out. The temperature profile is shown in Fig. 33. These data support previous evidence that this well has no liquid phase.

The three-arm caliper was deployed in the casing to $500 \mathrm{~m}$. The resulting data showed only the casing inner diameter. A fluid sample was taken at $650 \mathrm{~m}$ under static well conditions and as expected, very little liquid was in the sample.

The STP tool was rigged up for a flowing log. The tool was lowered to $200 \mathrm{~m}$ before the well was opened for flow. The wellhead pressure and the mass flow increased enough to push the logging cable out of the Bowen packoff and lift the STP tool up the well. The well was then shut in to drop the pressure and mass flow, allowing the tool to free-fall back into the well. The tool was then successfully lowered to $300 \mathrm{~m}$, and the well was again opened for flow. This time the tool and cable logging rate could be controlled, and the survey was completed to a depth of $650 \mathrm{~m}$. The well, however, was shut in as a safety precaution when the tool reached $400 \mathrm{~m}$ coming out. The spinner output, hertz versus depth, is plotted in Fig. 34. Since the fluid in the entire wellbore was in the two-phase region, there was no way to determine the enthalpy reference, so no attempt was made to calculate the thermodynamic flow parameters in well AH-22.

\section{Summary}

The Phase II field operations provided a total of 16 separate logs in four wells. The recurring problem of running continuous surveys with the lighter weight instruments, from the surface, through the casing-slotted liner interface inhibited by high well flow rates became a larger impediment during the Phase II work.

Occasional computer system failures, which required time-consuming field repairs, were also troublesome in Phase II. The HP9845 computer system, including the associated peripherals, is obsolete. This equipment should be replaced with new "field-hardened" systems available at reasonable cost. 


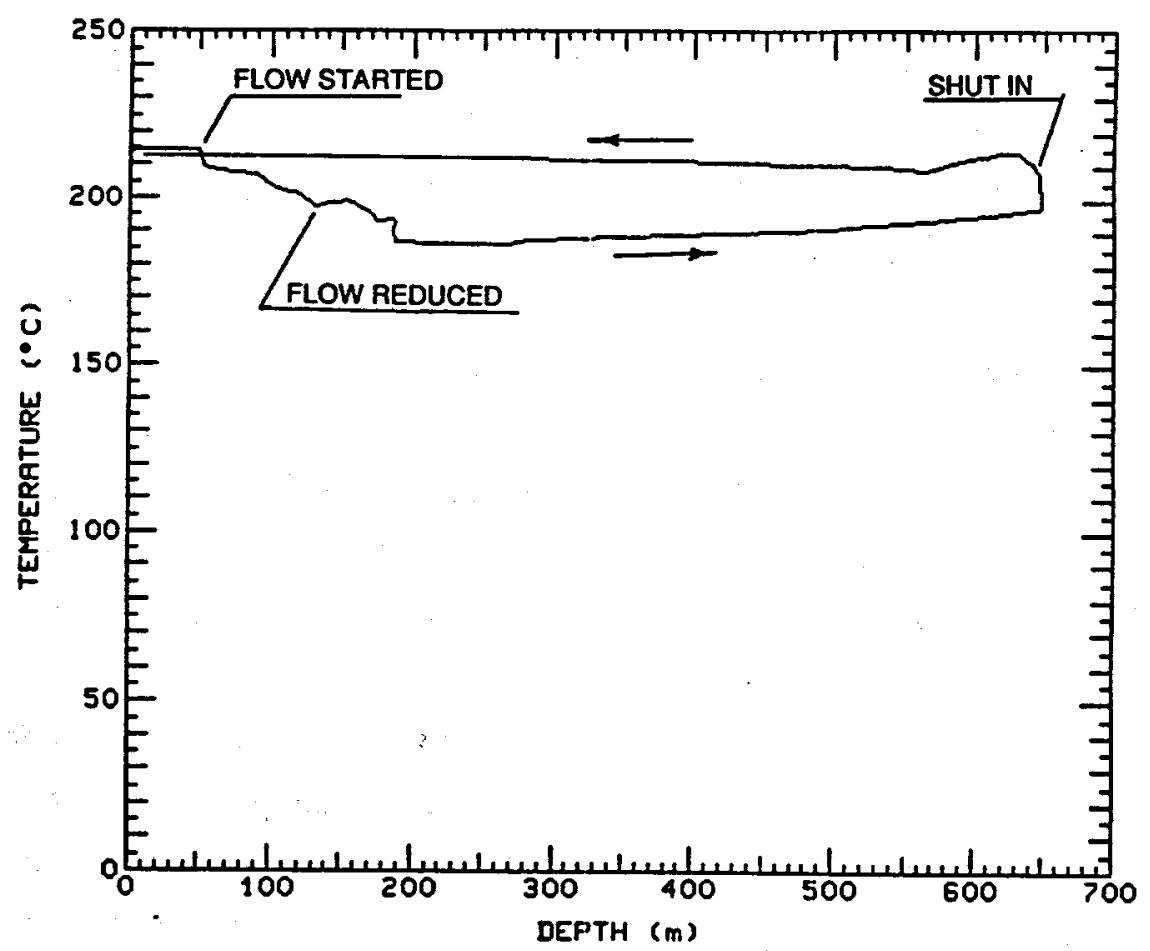

Fig. 33. Temperature/rabbit survey, AH-22.

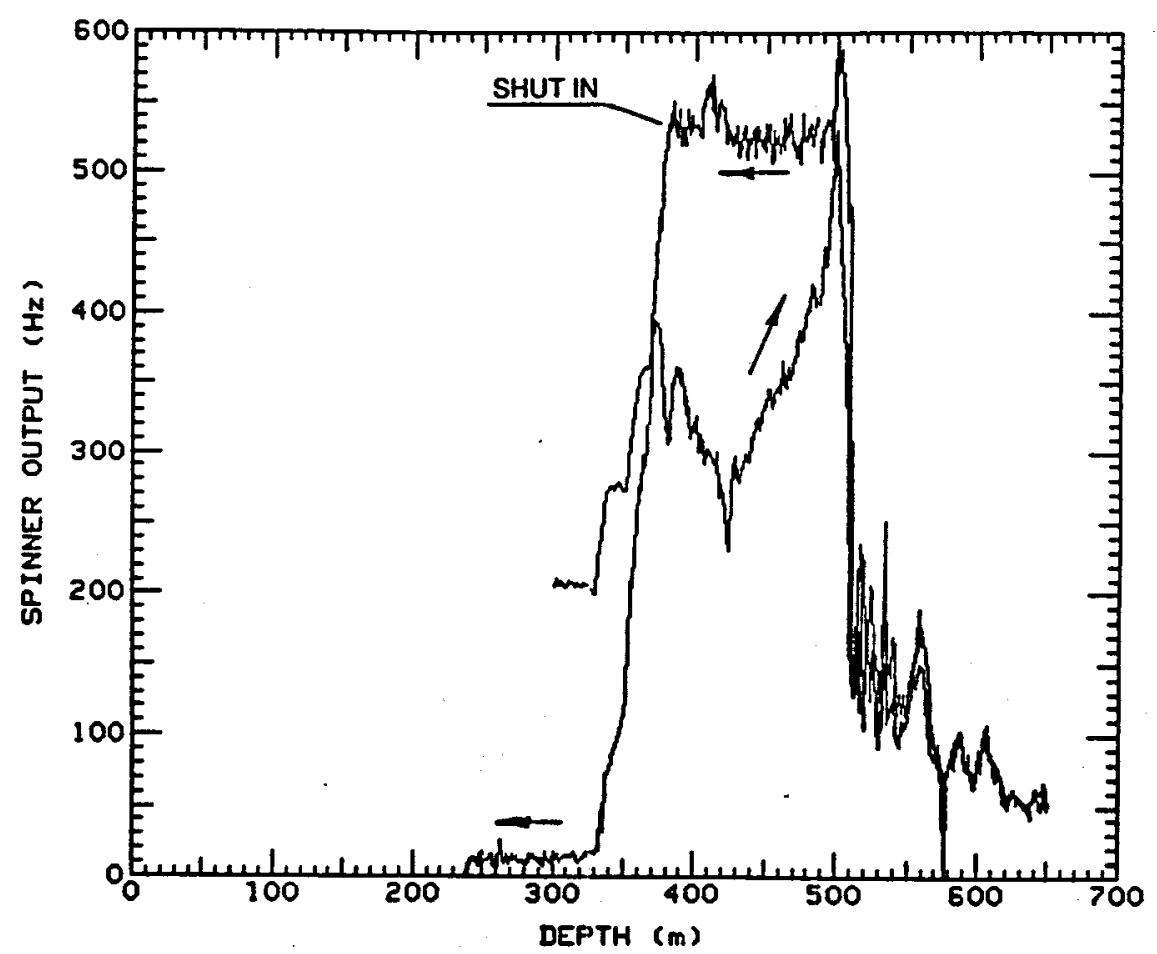

Fig. 34. STP spinner survey, AH-22. 
When the Phase II work was completed, all of the equipment was cleaned up and packed for shipment to the next scheduled field location.

\section{Discussion of Equipment-Related Problems}

The new logging truck, used for the first time in Ahuachapan Phase I operations, was equipped with a hydraulic generator that was driven from the "power takeoff" from the truck's hydraulic system. In order'to obtain the $60-\mathrm{Hz} 110-\mathrm{Vac}$ power from this generator, the drive must run at $1700 \mathrm{rpm}$. Because the cable-drawn works are also driven by the hydraulic system, logging rates are difficult to control at this high rpm, especially near the top of the well when not much weight is on the logging cable. The problem was aggravated by the new mechanical break on the cable drum, which tended to grab, causing severe jerking. It was sometimes necessary to run the downhole tool into the well to about 100 to $200 \mathrm{~m}$ with the electric generator turned off until sufficient weight on the downhole system allowed smoother rate control. As more logs were performed, wear on the brake pads alleviated this problem.

The impellers and bearings on the fluid velocity (spinner) transducer were designed for mass flow rates of around $25 \mathrm{~kg} / \mathrm{s}$. The much higher flow rates encountered in the Ahuachapán wells during the Phase I operations damaged these impellers. New impellers designed for use in the Phase II work resolved this problem.

The centralizer springs on the three-arm caliper and the STP tools frequently broke after several runs. The damage usually occurred at the weld around the holding pins at each end of the centralizer. Later analysis showed welds of poor quality that would fatigue from the thermal and mechanical shock during the logging operations. New springs made of Inconel were purchased for the Phase II work.

The temperature tool with the ring gauge or rabbit attached had difficulty entering the 194-mm (7-5/8-in.) slotted liners when the wells were flowing above $20 \mathrm{~kg} / \mathrm{s}$. It was necessary to shut in the well or reduce flow until the tool entered the liner.

Also, starting the downhole tools was difficult in some wells when combined flow rates and well head pressures were high enough to exceed the downward force from the tool. Using the STP tool with its small mass was 
especially troublesome. To overcome this difficulty a sinker bar will be designed to add about $54.4 \mathrm{~kg}(120 \mathrm{lb})$ to the mass of the STP tool. The sinker bar will be installed between the cablehead and the downhole instrument.

The data acquisition system in the logging truck must be upgraded to a field-hardened system such as the HP3852A Data Acquisition/Control System, which is designed specifically for remote field operations. This type of system is more easily maintained in the field; it is hardware intensive, which allows an expedient, more efficient systems transfer to the Central American operators.

\section{IN SITU FLUID SAMPLING}

In situ (downhole) fluid samples were obtained as part of the well logging program at Ahuachapan to help resolve specific problems about the wells and to help understand reservoir processes (as described in Section II). In situ samples were obtained in seven of the eight wells logged as were samples from the weirbox and steam separator (Table III). In addition, several samples of hot and cold springs, hot and cold wells, fumaroles, and rainwater were obtained to provide other background information on recharge, mixing, and dilution of the reservoir. Samples were collected in September 1987 and April 1988. Locations of all samples are shown in Fig. 35.

\section{A. Los Alamos in Situ Sampler}

The basic design of the Los Alamos in situ sampler was first described by Archuleta et al. (1978); its field application is reported in Goff et al. (1987a) and Grigsby et al. (1989). The tool has been modified several times since its original construction and was fitted with nominal 2 - and 4- $l$ sample chambers for the Ahuachapan project (Fig. A-4). Because the sample chamber is typically fabricated from stainless steel, anomalous concentrations of certain trace metals sometimes appear in the chemistry of in situ samples (parts per billion levels), and excess hydrogen gas can be produced by reaction of hightemperature brine with steel (described below).

The sampler is evacuated at the surface with a vacuum pump, is lowered to the desired depth on a seven-conductor cable, and is opened electrically from 
TABLE III. FIELD DATA OF WELL, SPRING, FUMAROLE, aND SURFACE SAMPLES, AHUACHAPAN, EL SALYAdoR

\begin{tabular}{|c|c|c|c|c|c|c|c|c|}
\hline \multirow[b]{2}{*}{$\begin{array}{l}\text { Sample } \\
\text { No. }\end{array}$} & \multirow[b]{2}{*}{ Description } & \multirow[b]{2}{*}{ Date } & \multirow[b]{2}{*}{$\begin{array}{l}\text { Dopth } \\
\text { (m) }\end{array}$} & \multirow[b]{2}{*}{$\begin{array}{l}\text { Temp. } \\
\left({ }^{\circ} \mathrm{C}\right)\end{array}$} & \multirow[b]{2}{*}{$\begin{array}{l}\text { Field } \\
\text { (pH) }\end{array}$} & \multirow[b]{2}{*}{$\begin{array}{l}\text { Flow Rate } \\
(1 / \mathrm{min}) \\
\end{array}$} & \multicolumn{2}{|c|}{ In situ Tool } \\
\hline & & & & & & & $\begin{array}{l}\text { Size } \\
\text { (1) }\end{array}$ & $\begin{array}{l}\text { Volume Collected } \\
\text { (1) }\end{array}$ \\
\hline ELS-1 & Well AH-1, in situ & 9/11/87 & 1100 & 222.9 & 5.80 & 1752 & 4 & 3.415 \\
\hline ELS-2 & $\begin{array}{l}\text { Well AH-1, flowline, } \\
\text { gas only }\end{array}$ & 9/11/87 & -- & $>100$ & $-\cdots$ & -- & -- & -- \\
\hline ELS-3 & Well AH-1, weirbox & 9/11/87 & $\because-$ & 98 & 7.19 & -- & $\cdots$ & -- \\
\hline ELS-4 & Woll AH-1, weirbox. & $8 / 12 / 87$ & $\therefore-$ & 98 & 7.05 & --- & -- & --- \\
\hline ELS-5 & Mell $A H-1$, in situ & $9 / 12 / 87$ & 660 & 223 & 6.75 & 1770 & 4 & 0.587 \\
\hline ELS-6 & $\begin{array}{l}\text { Well AH-27, flowlino, } \\
\text { gas only }\end{array}$ & $8 / 13 / 87$ & $\cdots$ & 142 & -- & -- & -- & --- \\
\hline ELS-7 & Woll AH-27, woirbox & $9 / 13 / 87$ & - & 98 & 7.05 & -- & -- & --- \\
\hline ELS-8 & Well AH-27, in situ & 9/13/87 & 725 & 240 & 6.83 & -- & 4 & 3.130 \\
\hline ELS-9 & El Salitre Hot Spring & $8 / 13 / 87$ & -- & 70.2 & 7.43 & 45 & $\cdots$ & --- \\
\hline ELS-10 & La Coiba Hot Spring & 8/13/87 & -- & 62.5 & 7.05 & 600 & -- & -- \\
\hline ELS-11 & La Labor Fumarole & $9 / 14 / 87$ & --- & 98 & -- & --- & -- & -- \\
\hline ELS-12 & Unnamed Cold Spring & 8/14/87 & $\cdots$ & 25 & 6.46 & $-\cdots$ & $\cdots$ & --- \\
\hline ELS-13 & Well AH-20, in situ & 8/15/87 & 630 & 230 & 6.48 & -- & 4 & 3.286 \\
\hline ELS-14 & Rainwater at $A H-18$ & $8 / 16 / 87$ & -- & $<25$ & 7.12 & -- & -- & --- \\
\hline ELS-15 & $\begin{array}{l}\text { Well AH-18, wellhead, } \\
\text { gas only }\end{array}$ & $9 / 18 / 87$ & -- & $>100$ & -- & --- & -- & -- \\
\hline ELS-16 & Well AH-18, in situ. & 8/18/87 & 1100: & 255 & 5.62 & -- & 4 & 3.036 \\
\hline ELS-17 & Woll $A H-18$, in situ & 9/17/87 & 760 & 255 & 5.90 & -- & 4 & 2.088 \\
\hline ELS-18 & El Sauce Fumarole & $9 / 18 / 87$ & $\cdots$ & 98 & -- & -- & -- & -- \\
\hline ELS-19 & $\begin{array}{l}\text { Cold Spring, } \\
\text { Finca La Victoria }\end{array}$ & $9 / 18 / 87$ & -- & $<25$ & 6.13 & --- & -- & -- \\
\hline ELS-20 & Fumarole near $\mathrm{AH}-18$ & 9/18/87 & $\cdots$ & 98 & $\cdots$ & -- & $\cdots$ & -- \\
\hline ELS-21 & El Playón Fumarole. & 9/18/87 & -- & 98 & -- & -- & -- & -- \\
\hline ELS-22 & Well $\mathrm{AH}-32$, in situ. & $4 / 15 / 88$ & 925 & 240 & 6.00 & -- & 2 & 1.499 \\
\hline ELS-23 & Well AH-16 in situ & $4 / 16 / 88$ & 650 & 231 & -- & -- & 4 & $0.081^{b}$ \\
\hline ELS-24 & Well AH-16, weirbox & $4 / 16 / 88$ & -- & 98 & 6.83 & -- & - & -- \\
\hline ELS-26 & Cold Well 439 . & $4 / 17 / 88$ & 21.5 & 28.3 & 6.00 & --- & $-\infty$ & -- \\
\hline ELS-26 & Cold Woll 385 & $4 / 17 / 88$ & 6.1 & 28 & 6.00 & --- & -- & -- \\
\hline ELS-27 & Hot Spring \#F-719 & $4 / 17 / 88$ & --- & 48.3 & 6.50 & $\cdots$ & -- & -- \\
\hline ELS-28 & Hot Woll $468 \mathrm{~A}$ & $4 / 17 / 88$ & -- & 47.4 & 7.25 & $-\cdots$ & -- & -- \\
\hline ELS-29 & $\begin{array}{l}\text { Hot Spring at AH-20 } \\
\text { well head }\end{array}$ & $4 / 17 / 88$ & -- & 98.4 & 7.60 & -- & -- & --- \\
\hline ELS-30 & Woll AH-22, in situ & $4 / 18 / 88$ & 850 & 214 & 6.00 & --- & 4 & 2.806 \\
\hline ELS-31 & Well AH-22, cyclono & $4 / 19 / 88$ & $\cdots$ & 107.2 & 5.60 & -- & -- & -- \\
\hline ELS-32 & Well AH-22, weber & $4 / 19 / 88$ & $\cdots$ & 136 & 6.60 & -- & $-\cdots$ & -- \\
\hline ELS-33 & Well AH-22, weber & $4 / 19 / 88$ & -- & 136 & 6.60 & -- & $\cdots$ & -- \\
\hline ELS-34 & Woll AH-16, weber. & $4 / 20 / 88$ & $\cdots$ & 140 & 6.00 & $\cdots$ & $\because$ & -- \\
\hline ELS-35 & Well AH-16, weber & $4 / 20 / 88$ & -- & 140 & 6.00 & -- & $\cdots$ & $\cdots$ \\
\hline
\end{tabular}

"Samples AH-1 to AH-21 collected by C. O. Grigsby; all other samples collected by A. Adams.

bample bottle did not fill adequately for unknown reason. 


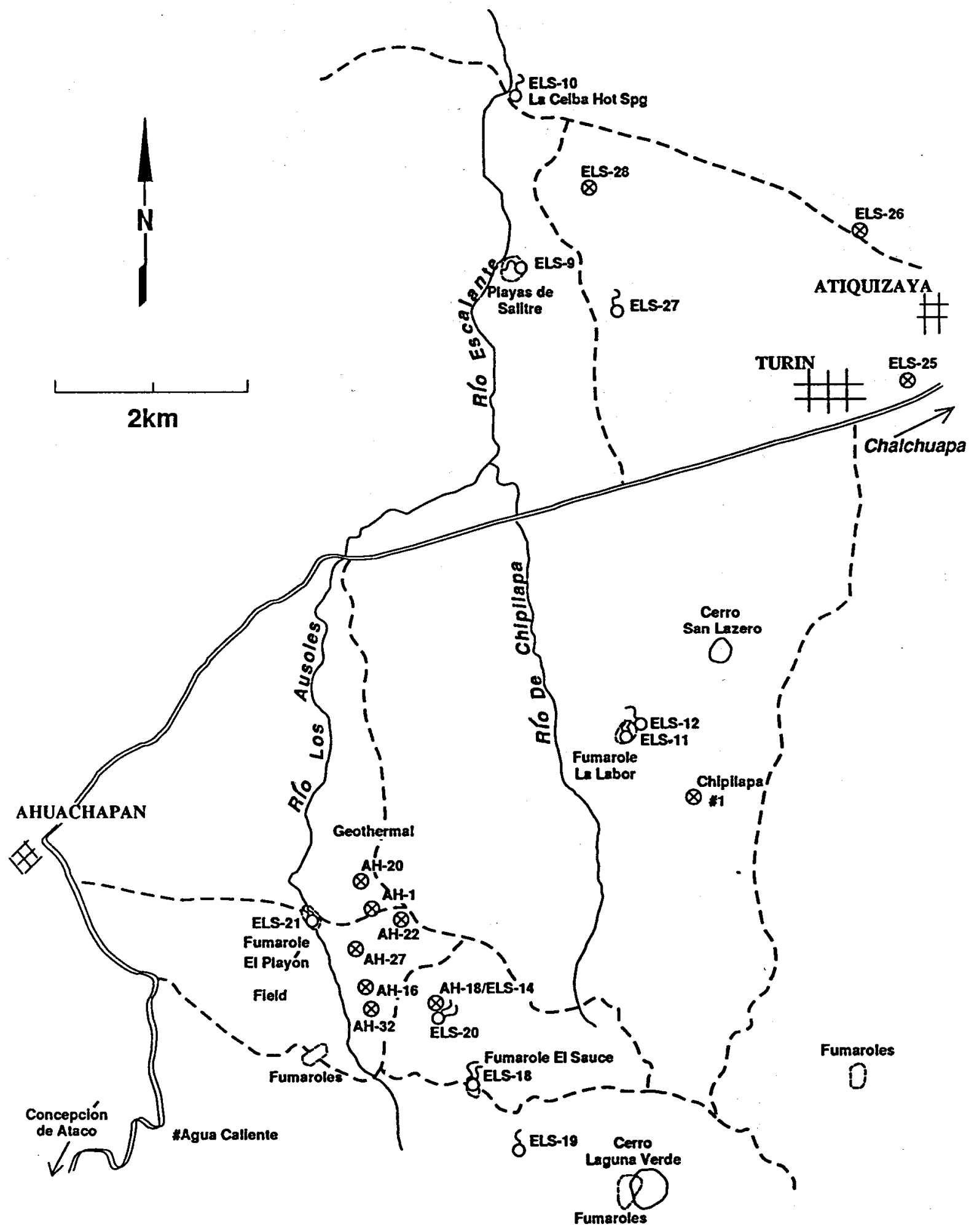

Fig. 35. Location map of Ahuachapán area showing locations of all wells and springs sampled for this investigation. 
the surface by triggering a temperature-hardened motor connected to a clutch and valve assembly. The tool is left open $210 \mathrm{~s}$, and the motor is retriggered to close the valve. When the sampler returns to the surface, it contains a pressurized sample of fluid. For geothermal samples where temperatures greatly exceed $100^{\circ} \mathrm{C}$, the liquid sample increases in density as the tool is cooled during removal from the well. Increase in fluid density causes the fluid volume to decrease; thus, a "head space" is formed in the sample chamber that fills with gases separating from the fluid.

To obtain precise information on downhole composition, both the gas and the fluid compositions must be determined quantitatively (Goff et al., 1987a). First, the gas must be removed by using a gas extraction system (GES). The volume of the GES and its various subsystems must be accurately known. The GES used at Ahuachapán is shown schematically in Fig. 36. To prevent any loss of steam, the sample chamber is cooled to $570^{\circ} \mathrm{C}$ before gas removal. A temperature probe in the sample chamber is used to monitor internal temperature.

The GES is evacuated using a vacuum pump, the sample chamber is opened to release gas into the GES, and the pressure in the GES is recorded. The gas is then released into either a flow-through or a caustic gas bottle for later analysis. Basically, the total moles of gas extracted can be calculated using the ideal gas law,

$$
n=\frac{P V}{R T} \text {, }
$$

where $n=$ moles of gas, $P=$ gas pressure (converted to atmospheres), $V=$ gas volume (converted to liters), $T=$ temperature $(K)$, and $R=$ the universal gas constant. For a complete description of GES procedures, the reader should consult Goff et al. (1987a).

After the GES procedures are completed, the sample chamber is opened, geothermal brine is poured into a tared beaker, and the weight of brine is measured on a top-loading balance. If the brine is relatively concentrated, an aliquot is immediately pipetted from the beaker into a tared pycnometer, the aliquot is weighed, and brine density is calculated. Because Ahuachapán fluids contain $<10,000 \mathrm{mg} / \mathrm{kg} \mathrm{Cl}$, brine density was not calculated and densities are assumed to be approximately 1.0 at $25^{\circ} \mathrm{C}$. Next, an aliquot is used to measure $\mathrm{pH}$ and any other parameters that a geochemist may wish to determine in the 


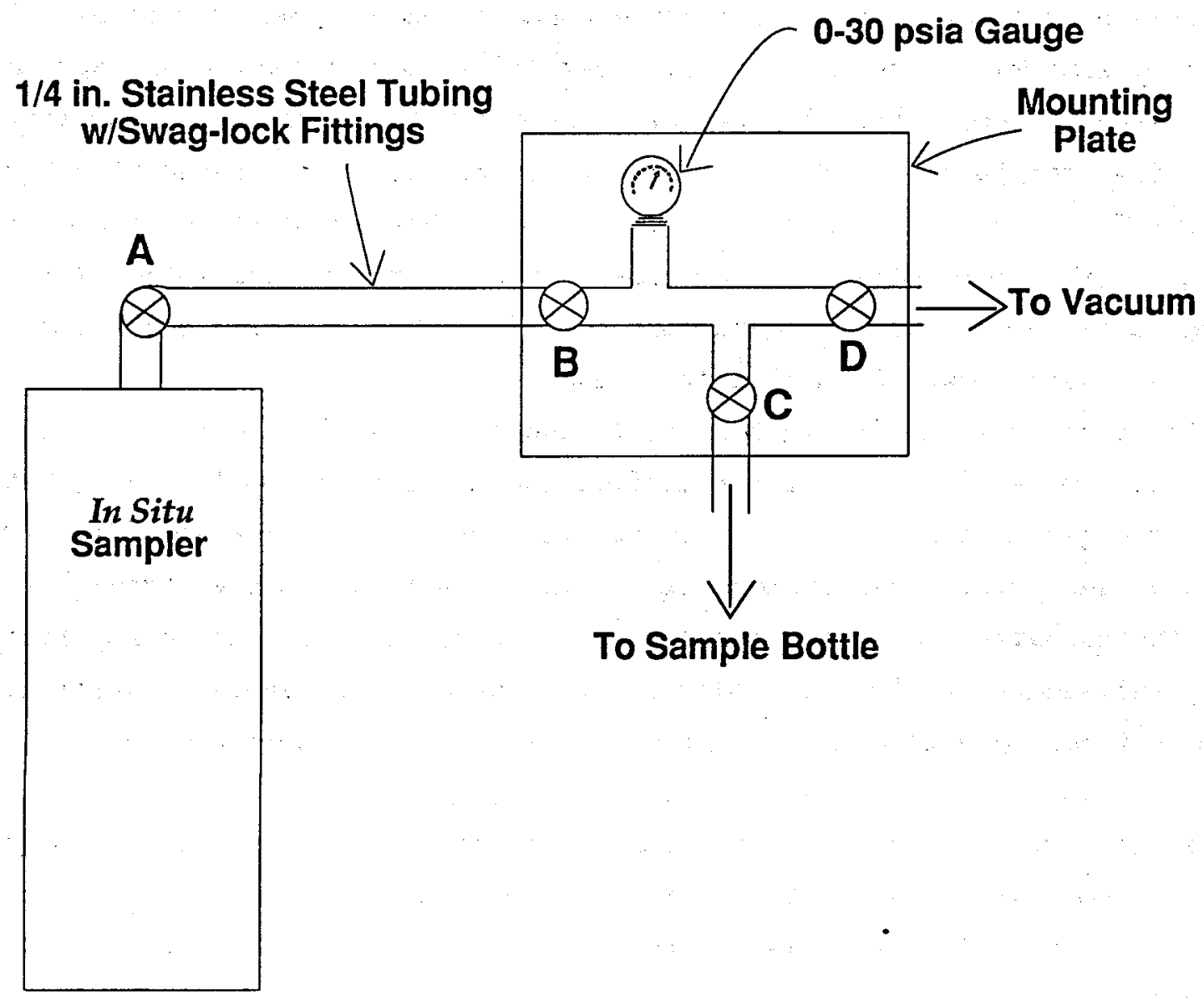

Fig. 36. Sketch of gas extraction system (GES) used for this investigation.

field. Finally, the fluid sample is split and preserved for various chemical and isotopic analyses (Trujillo et al., 1987).

Procedures used to collect the other Ahuachapan samples discussed in this report vary depending on the situation (spring, fumarole, nonflowing well, separator, weirbox). Consult Trujillo et al. (1987) for methods of collection.

\section{B. Fluid Compositions}

Ahuachapán geothermal fluids sampled during this study $(6,000$ to $9,000 \mathrm{mg} / \mathrm{kg} \mathrm{Cl}$ ) occur on the concentrated side of the typical range of geothermal brine compositions $(1,000$ to $10,000 \mathrm{mg} / \mathrm{kg} \mathrm{Cl}$ ) (Fournier et al., 1981, Table 4.2). As can be seen in Tables IV and V, Ahuachapán fluids contain 
table iv. mater analyses of well, spring, and surface samples, ahunchapan, el salvadon (Analyeov by P. E. Trujillo and D. Counce)

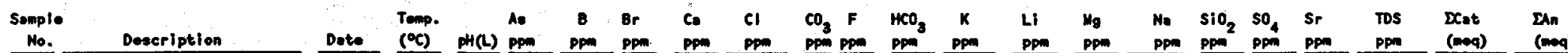

Miselleneoue samoles

\begin{tabular}{|c|c|c|c|c|c|c|c|c|c|c|c|c|c|c|c|c|c|c|c|c|c|c|}
\hline \multirow{3}{*}{\multicolumn{2}{|c|}{$\begin{array}{l}\text { Miscedleneove Samples } \\
\text { ELS-9 El Solitre Hot Spg. (F717) } \\
\text { ELS-10 L Coibo Hot Spg. }\end{array}$}} & & & & & & & & & & & & & & & & & & & & & \\
\hline & & 9/13/87 & 70.2 & 7.43 & 1.3 & 8.14 & 0.2 & 15.1 & 87.4 & 0 & 0.37 & 492 & 21.2 & 0.05 & 3.36 & 210 & 178 & 29.5 & 0.14 & 1049.6 & 10.797 & 11.465 \\
\hline & & 9/13/87 & 52.5 & 7.05 & 0.6 & 4.24 & 0.4 & 26.8 & 166 & 0 & 0.28 & 821 & 25.0 & 0.55 & 7.03 & 182 & 106 & 19.0 & 0.17 & 923.0 & 10.477 & 20.617 \\
\hline LS-12 & Unnamed Cold Spg & 9/14/87 & -- & 0.46 & $<0.05$ & $<0.05$ & $<0.1$ & 20.2 & 3.2 & 0 & 0.09 & 78.0 & 5.9 & $<0.02$ & 0.80 & 8.8 & 64 & 81.8 & 0.22 & 254.1 & 2.410 & 2.606 \\
\hline LS-14 & Rolmwoter st AH & $9 / 18 / 87$ & - & 7.12 & $<0.05$ & 0.08 & $<0.1$ & 18.8 & 17.0 & 0 & 0.09 & 112 & 58 & $<0.01$ & 2.01 & 2 & $<1$ & 0.5 & 0.04 & 23.3 & 2.604 & 2.607 \\
\hline$s-10$ & Fines Le Victor & $9 / 18 / 87$ & - & 6.13 & $<0.05$ & $<0.05$ & $<0.1$ & 7.2 & 2.0 & 9 & 0.09 & & 5.8 & o. & 6. & 10.0 & 100 & 23.0 & o. & 303.4 & 22 & 2.042 \\
\hline ELS-27 & $\begin{array}{l}\text { Hot Spg. } F-719, \\
\text { El solitre Crook }\end{array}$ & $4 / 17 / 88$ & 48.8 & 7.66 & 0.91 & 3.48 & 0.5 & 21.0 & 120 & 0 & 0.37 & 345 & 24.0 & 0.52 & 7.46 & 178 & 280 & 21.4 & 0.13 & 890.4 & 10.037 & 9.736 \\
\hline$S-28$ & Woll AH-20, spgs. & 4/17/80 & 98.4 & 8.89 & $<0.05$ & 1.50 & 0.9 & 70.5 & 177 & 0 & 0.50 & 134 & 43 & $<0.02$ & 0.11 & 100 & 165 & 95.2 & 0.79 & 783.6 & 9.157 & 9.252 \\
\hline
\end{tabular}
ELS-20 Woll AH-20, spge.

$\begin{array}{lllllllllllll}4 / 17 / 89 & 98.4 & 8.89 & <0.05 & 1.50 & 0.9 & 70.5 & 177 & 0 & 0.50 & 134\end{array}$

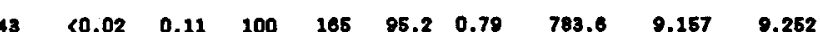

\section{Geothernel and Other Molles}

ELS-1 Woll AH-1, $1200 \mathrm{~m}$

ELS-3 Woll AH-1, wol rbox

ELS-5 WOII AH-1, BEO -

ELS-7 Woll AH-27, woirbox

ELS-8 Woll AH-27, 725 W

ELS-13 Woll AH-20, 630 -

ELS-16 Woll AH-18, $1100 \mathrm{~m}$

ELS-17 Woll AH-18, 750 -

ELS-22 Woll AH-32, 925 .

ELS-23 Woll $\mathrm{AH}-16,650 \mathrm{~m}$

ELS-24 Woll AH-16, woirtion

ELS-25 Cold Woll p439,

C kin ME Aluochopón
cold Woll p385,

$1 \mathrm{~km}$ W Atiquizay

ELS-28 Hot Woll $\$ 408$ A

ELS-30 Woll AH-22, 650 a

ELS-31

ELS-32 woll AH-22, cond. fr:

$\begin{array}{llllllllllllllllllllllll}9 / 11 / 87 & 222.9 & 5.80 & 8.3 & 126 & 25.8 & 549 & 8500 & 0 & 0.85 & 31.7 & 050 & 14.5 & 0.31 & 4090 & 411 & 30.1 & 5.32 & 15443,3 & 259.500 & 244.332\end{array}$ $\begin{array}{lllllllllllllllllllll}9 / 11 / 87 & 98 & 7.19 & 9.1 & 129 & 24.6 & 418 & 8820 & 0 & 1.11 & 42.7 & 709 & 16.0 & 0.22 & 5210 & 488 & 39.5 & 4.16 & 25919.5 & 263.906 & 251.092\end{array}$

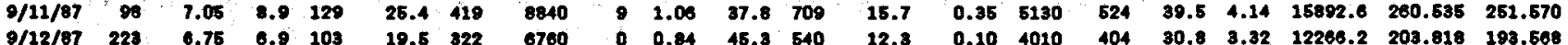
$\begin{array}{lllllllllllllllllllll}9 / 12 / 87 & 223 & 6.75 & 6.9 & 103 & 19.5 & 322 & 6780 & 0 & 0.84 & 45.3 & 540 & 12.3 & 0.10 & 4010 & 404 & 30.8 & 3.32 & 12286.2 & 203.818 & 193.568 \\ 0 / 12 / 87 & 98 & 7.05 & 10.5 & 145 & 27.6 & 370 & 10030 & 0 & 3.25 & 46.4 & 1000 & 20.1 & 0.21 & 5820 & 042 & 28.2 & 3.72 & 18155.2 & 294.938 & 284.434\end{array}$ $\begin{array}{lllllllllllllllllllll}9 / 12 / 87 & 98 & 7.05 & 10.5 & 145 & 27.6 & 370 & 10030 & 0 & 1.25 & 46.4 & 1000 & 20.1 & 0.21 & 5820 & 642 & 28.2 & 3.72 & 18155.2 & 294.938 & 284.434 \\ 9 / 13 / 87 & 240 & 8.83 & 8.0 & 118 & 23.4 & 293 & 7820 & 0 & 1.04 & 45.1 & 800 & 16.1 & 0.16 & 4680 & 633 & 22.4 & 2.06 & 14371.5 & 237.734 & 223.015\end{array}$

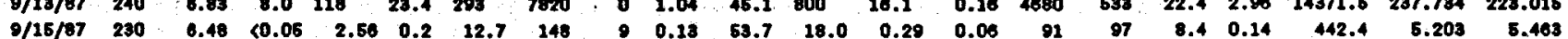

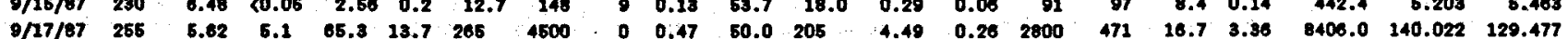

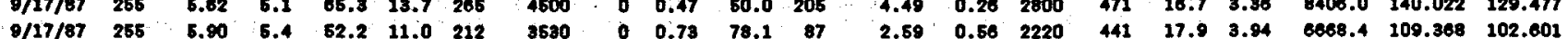

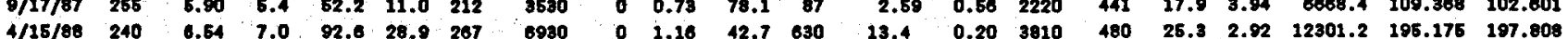

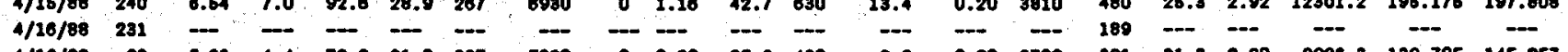
$\begin{array}{lllllllllllllllllllll}4 / 18 / 80 & 96 & 6.93 & 4.4 & 72.9 & 21.0 & 227 & 6080 & 0 & 0.80 & 25.0 & 420 & 0.6 & 0.20 & 2700 & 381 & 31.3 & 2.80 & 8986.3 & 139.705 & 145.857\end{array}$

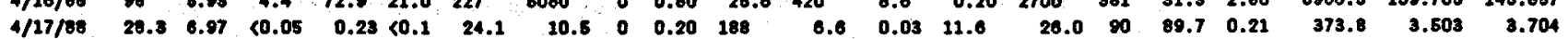
$\begin{array}{lllllllllllllllllllllll}4 / 17 / 88 & 28 & 0.86 & <0.05 & 0.14<0.1 & 46.6 & 24.8 & 0 & 0.18 & 212 & 7.2 & 0.02 & 19.9 & 28.2 & 99 & 23.4 & 0.28 & 523.0 & 5.307 & 5.696\end{array}$

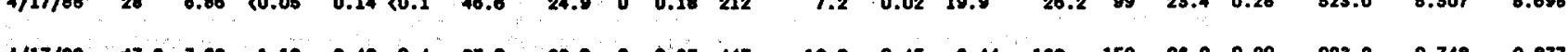
$\begin{array}{rrrllllllllllllllllll}4 / 17 / 88 & 47.3 & 7.83 & 1.18 & 2.49 & 0.4 & 27.0 & 62.0 & 0 & 0.35 & 447 & 19.2 & 0.45 & 6.44 & 168 & 159 & 28.2 & 0.20 & 923.2 & 9.748 & 9.877 \\ 4 / 18 / 88 & 214 & 6.79 & 6.1 & 89.2 & 27.4 & 252 & 6670 & 0 & 1.02 & 37.8 & 625 & 10.7 & 0.15 & 3625 & 441 & 29.8 & 3.32 & 11718.2 & 183.279 & 190.525\end{array}$ $\begin{array}{llllllllllllllllllllll}4 / 19 / 88 & 107 & 0.15 & 0.05 & 1.45 & 0.1 & 0 & 10.7 & 0 & 0.03 & 24.4 & 1.1 & <0.02 & 0.06 & 0.2 & 2 & <0.5 & 0.04 & 48.7 & 0.402 & 0.780\end{array}$

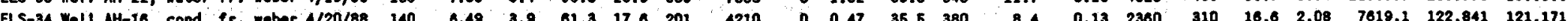

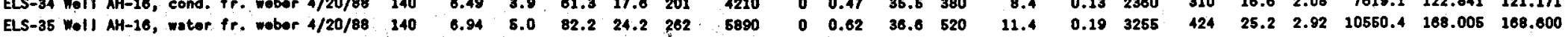




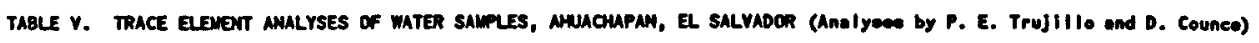

Sopplo

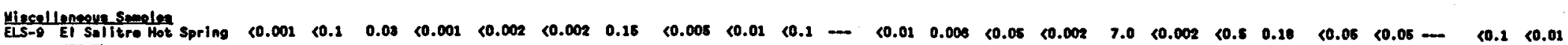
(Fr1)

ELS-10 Lo coibo Hot Spring

ELS-12 Unnemed Cold Spring ELS-10 Fines lo vietorio, Cold Spring

ELS-27 Hot Spring NF-719,

ELS-29 Woll AH-20, Springe

$\begin{array}{lllllllllllllllllllllllll}<0.001 & <0.1 & 0.05 & <0.001 & <0.002 & <0.002 & 0.069 & <0.005 & <0.01<0.1 & - & 0.01 & 0.007 & 0.05 & <0.002 & 5.9 & <0.002 & <0.5 & 0.14 & <0.05<0.05 & -\end{array}$

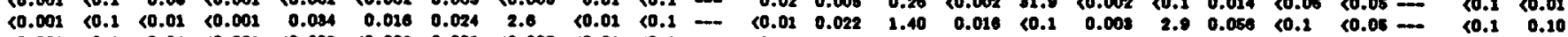

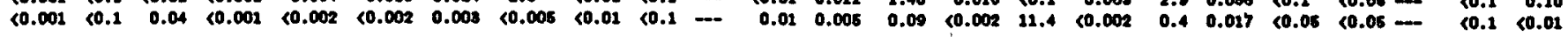

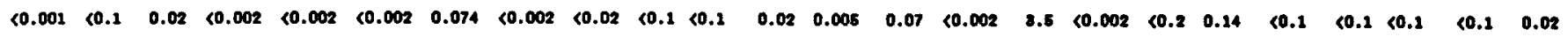
$\begin{array}{lllllllllllllllllllllllllllllllllll}<0.001 & <0.1 & 0.14 & <0.002 & <0.002 & <0.002 & 0.019 & 0.005 & <.02 & <0.1 & <.1 & 0.12 & 0.004 & 2.06 & 0.010 & <0.1 & <0.002 & <0.2 & 0.22 & <0.1 & <0.1 & <0.1 & <0.1 & 0.03\end{array}$

Geothereal and other melle

ELS-1 Moll At-1, 1100 m ELS-3 ELs-4 ELS ELS-8 Woll AHt-27, 725 " ELS-13 Woll AH-20, 630 . ELS-16 Woll AH-10, 1100 . ELS-17 Woll AH+18, 750 . ELS-22 Woll AH-22, 225 .

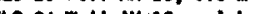
Eis-35 cold Moll was - kn WE Ahuschope ELS-26 cold Woll pses. i ko W Atiquizay ELS-28 Hot Woll 1468h ELS-30 ELS-32 trom webor ELS-33 Woll AH-22, wetor frow mober Gell Att-16, cond. ELS-35 Woll mob-16, woter

$\begin{array}{lllllllllllll}<0.001 & <0.2 & 0.49 & <0.001 & 0.002 & 0.002 & 2.62 & <0.005 & 1.20 & <0.2 & \cdots & 1.0\end{array}$ $\begin{array}{llllllllllllllll}1.01 & 0.017 & 0.00 & 0.022<0.8 & <0.002 & <0.5 & 4.24 & <0.1 & <0.1 & - & 0.1 & 0.02\end{array}$ $\begin{array}{lllllllllllllll} & 0.04\end{array}$

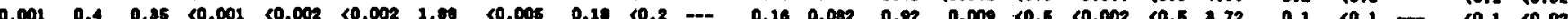

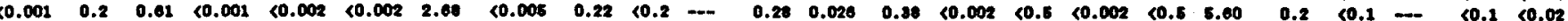

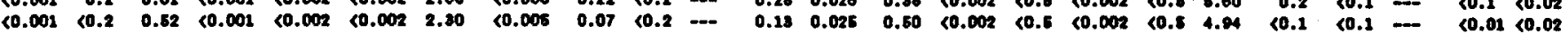

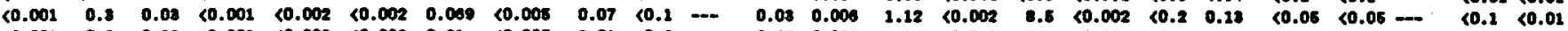

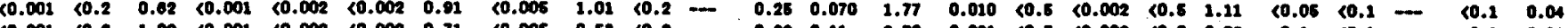

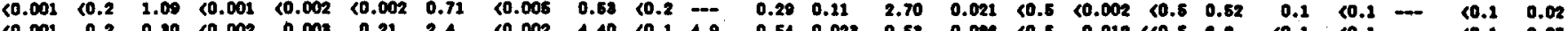

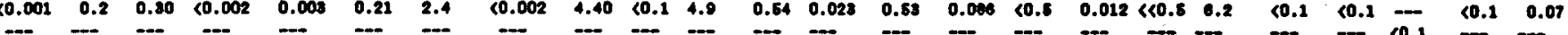

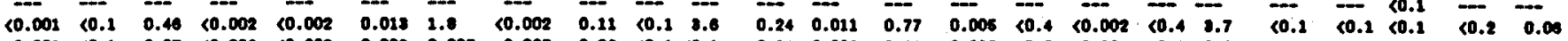
$\begin{array}{llllllllllllllllllllllllll}<0.001 & <0.1 & 0.07 & <0.002 & 80.002 & 0.003 & 0.005 & 0.005 & 0.00 & <0.1 & <0.1 & 0.34 & 0.003 & 0.81 & 0.008 & 7.7 & <0.002 & <0.2 & 0.042 & <0.1 & <0.1 & <0.1 & <0.1 & 0.06\end{array}$

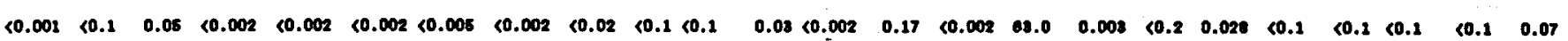
$\begin{array}{lllllllllllllllllllllllllll}<0.001 & <0.1 & 0.10 & <0.002 & <0.002 & <0.002 & 0.053 & <0.002 & <0.02 & <0.1 & <0.1 & 0.04 & 0.003 & 0.10 & <0.002 & 8.2 & 0.004 & <0.2 & 0.12 & <0.2 & <0.1 & <0.1 & <0.1 & 0.03\end{array}$

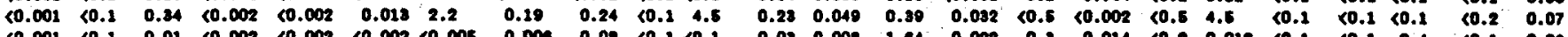

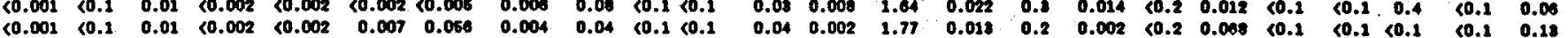
$\begin{array}{lllllllllllllllllllllllllllll}<0.001 & 0.1 & 0.41 & <0.002 & <0.002 & <0.002 & 2.3 & <0.002 & 0.10 & <0.1 & 4.8 & 0.10 & 0.026 & 0.20 & <0.002 & <0.5 & <0.002 & <0.5 & 4.0 & <0.1 & <0.1 & <0.1 & <0.2 & 0.16\end{array}$ $\begin{array}{llllllllllllllllllllllllllllllll}0.001 & <0.1 & 0.28 & <0.002 & <0.002 & <0.002 & 1.7 & <0.002 & <0.02 & <0.1 & 3.0 & 0.05 & 0.014 & 0.07 & <0.002 & <0.6 & <0.002 & <0.5 & 3.4 & <0.1 & <0.1 & 2.8 & <0.2 & 0.07\end{array}$

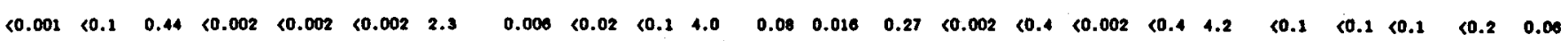

Sample bottle did not flill adequately for unknown reason; thus, no chemistry performed. 
relatively high $\mathrm{Na}, K$, and $L i$, and unusually high $A s, B, B r, I, C s, R b$, and $C a$ compared with "typical" high-temperature geothermal fluids. Because of these anomalies, it is very easy, to trace mixing processes of Ahuachapán geothermal fluids with other types of waters. For example, many Ahuachapan hot springs are obvious mixtures of shallow groundwater and some geothermal brine (e.g., El Salitre Hot Spring; La Ceiba Hot Spring) because the springs contain relatively high $\mathrm{As}, \mathrm{B}, \mathrm{Br}, \mathrm{Li}, \mathrm{Cs}$, and $\mathrm{Rb}$ compared with $\mathrm{Cl}$. These same springs, however, show high $\mathrm{HCO}_{3} / \mathrm{Cl}$ compared with geothermal brine, suggesting that subsurface boiling (and loss of $\mathrm{CO}_{2}$ ) is also occurring locally in the subsurface near the top of the reservoir. The fumaroles that occur at the surface of the geothermal field substantiate this claim. As mentioned above, some in situ samples contain slightly anomalous concentrations of $\mathrm{Co}, \mathrm{Cr}$, and $\mathrm{Ni}$ (22 ppb) compared with total flow samples because of the reaction of hot geothermal fluid with stainless steel (Table $V$ ). A detailed investigation of trace element concentration resulting from reaction of geothermal brine with stainless steel is beyond the scope of this report because few trace elements have been found to be of value for interpretation of geothermal processes. Their inclusion in Table $V$ is mostly a courtesy.

Gas analyses from various sources in the Ahuachapán area are listed in Table VI. Ahuachapán gases resemble geothermal gases from volcanically driven systems the world over. (D'Amore and Panichi, 1980). The dominant gas is $\mathrm{CO}_{2}$ (generally $\geq 85$ vol\%, dry gas) followed by the others in slightly varying proportions. The chemical character of fumarole samples is similar to well samples. However, analyses of gases from in situ samples are usually less precise than other samples because of the relatively low pressure of gas species in the geothermal fluid and the small volume of gas extractable from the in situ sample bottle. Typically, internal pressures in the in situ chamber were less than $0.3 \mathrm{~atm}$. As a result of these factors, flow-through gas bottles were used during the April sampling trip that gave slightly better information (ELS-22, -23, and -30). Another problem with in situ gas samples results from reactivity of the hot fluid with the stainless steel, producing excess $\mathrm{H}_{2}$ and consuming $\mathrm{H}_{2} \mathrm{~S}$. The magnitude of this problem can be assessed only if other types of gas samples are taken. 
TABLE VI. GAS ANALYSES OF WELL AND FUMAROLE SAMPLES, AHUACHAPAN, EL SALYADOR (All Values in volx Dry Gas Excopt Whore Notod")

\begin{tabular}{|c|c|c|c|c|c|c|c|c|c|c|c|c|c|c|c|c|}
\hline $\begin{array}{l}\text { Semple } \\
\text { No. }\end{array}$ & Date & Description & ${ }^{\text {Tomp }} \dot{ }$ & $\begin{array}{l}\text { Steam } \\
\text { Fraction }\end{array}$ & $\begin{array}{c}\text { Gas/Stosm } \\
\left(\mathrm{mol} / 10^{6} \mathrm{~mol}\right)\end{array}$ & $x$ Air & $\mathrm{CO}_{2}$ & $\mathrm{H}_{2} \mathrm{~S}$ & $\mathrm{NH}_{3}$ & Ar & $\mathrm{N}_{2}$ & $\mathrm{CH}_{4}$ & $\mathrm{H}_{2}$ & He & Tota 1 & $\begin{array}{c}\delta^{13} \mathrm{C}\left(\mathrm{CO}_{2}\right)^{\mathrm{t}} \\
(\% / 00)^{2}\end{array}$ \\
\hline ELS-1 & $9 / 11 / 87$ & $\begin{array}{l}\text { Well AH-1; downhole } \\
\text { sampler; } 1100 \mathrm{~m}\end{array}$ & $<70.0$ & --- & -- & 0.74 & 84.4 & $<0.242$ & $<0.17$ & 0.1051 & 12.60 & $<0.146$ & 2.16 & $<0.134$ & 98.27 & -6.28 \\
\hline ELS-2 & $9 / 11 / 87$ & Well AH-1; flowline & 149.0 & 0.156 & 428 & 71.04 & 88.3 & $<0.503$ & 0.381 & 0.108 & 9.48 & $<0.279$ & 0.651 & $<0.255$ & 88.92 & $-10.64 ?$ \\
\hline ELS-5 & $8 / 12 / 87$ & $\begin{array}{l}\text { Woll AH-1; downhole } \\
\text { semple, } 650 \mathrm{~m}\end{array}$ & $<70.0$ & -. & $-\infty$ & 2.84 & 95.3 & $<1.19$ & $<0.847$ & 0.016 & 0.99 & $<0.655$ & 0.415 & $<0.699$ & 96.72 & $\cdots$ \\
\hline ELS-6 & $8 / 13 / 87$ & Woll AH-27; flowline & 142.0 & 0.206 & 6024 & 0.10 & 97.3 & 0.816 & 0.020 & 0.002 & 1.55 & 0.023 & 0.285 & $<0.017$ & 100.01 & -2.85 \\
\hline ELS-8 & $9 / 13 / 87$ & $\begin{array}{l}\text { Woll AH-27; downhole } \\
\text { sampler, } 725 \mathrm{~m}\end{array}$ & $<70.0$ & $-\infty$ & 1446 & 1.63 & 88.4 & $<1.20$ & $<0.860$ & 0.093 & 7.91 & $<0.628$ & $<0.341$ & $<0.574$ & 96.40 & --- \\
\hline ELS-11 & $9 / 14 / 87$ & La Labor Fumarole & 98.0 & -- & 10670 & 0.44 & 96.8 & 0.360 & 0.017 & 0.015 & 2.68 & $<0.006$ & 0.131 & $<0.005$ & 100.00 & -3.26 \\
\hline ELS-13 & $9 / 15 / 87$ & $\begin{array}{l}\text { Woll AH-20; downhole } \\
\text { sompler, } 630 \mathrm{~m}\end{array}$ & $<70.0$ & $\cdots$ & --- & 3.81 & 92.8 & $<1.25$ & $<0.891$ & 0.038 & 3.64 & $<0.548$ & $<0.327$ & $<0.544$ & 96.48 & -- \\
\hline ELS-15 & $8 / 16 / 87$ & $\begin{array}{l}\text { Woll AH-18; rosidual } \\
\text { gas at wel lhood }\end{array}$ & $<70.0$ & -- & --- & 0.66 & 93.1 & $<0.008$ & $<0.008$ & 0.009 & 0.97 & 0.051 & 0.024 & $<0.004$ & 100.15 & $-1.78 ?$ \\
\hline ELS-16 & 9/16/87 & $\begin{array}{l}\text { Well AH-18; downhole } \\
\text { sampler, } 1100 \mathrm{~m}\end{array}$ & $<70.0$ & -- & 256520 & 0.61 & 91.1 & $<0.029$ & $<0.021$ & 0.022 & 7.94 & 0.068 & 0.762 & $<0.024$ & 99.89 & -2.09 \\
\hline ELS-18 & $9 / 18 / 87$ & EI Sauce Fumarole & 88.0 & -- & 81883 & 0.06 & 97.8 & 0.490 & $<0.006$ & 0.0009 & 9. 1.25 & $<0.005$ & 0.422 & $<0.005$ & 99.87 & -8.50 \\
\hline ELS-20 & $8 / 18 / 87$ & Fumarole near $A H-18$ & 98.0 & -- & 387032 & 0.03 & 88.3 & 0.147 & $<0.003$ & 0.001 & 1.44 & $<0.004$ & 0.125 & $<0.004$ & 100.01 & -3.87 \\
\hline ELS-21 & $9 / 18 / 87$ & EI Playón Fumarole & 98.0 & -- & 4500 & 14.70 & 92.7 & 0.671 & $<0.058$ & 0.054 & 0.28 & $<0.025$ & 0.168 & $<0.025$ & 99.87 & -3.99 \\
\hline ELS-22 ${ }^{C}$ & $1 / 15 / 88$ & $\begin{array}{l}\text { Woll AH-32; downhole } \\
\text { sampler, } 925 \mathrm{~m}\end{array}$ & $<70.0$ & -- & $\cdots$ & 84.00 & 97.7 & 0.008 & $\ldots$ & -- & -- & 0.038 & 2.20 & 0.005 & 100.00 & -3.20 \\
\hline ELS-23 ${ }^{d}$ & $4 / 16 / 88$ & $\begin{array}{l}\text { Well AH-16; downhole } \\
\text { sompler, } 650 \mathrm{~m}\end{array}$ & $<70.0$ & -- & -- & 96.70 & 95.6 & 0.015 & --- & $\cdots$ & -- & 0.059 & 4.04 & 0.025 & 100.00 & -4.70 \\
\hline ELS-29 & $1 / 17 / 88$ & $\begin{array}{l}\text { Gesoous hot springs } \\
\text { around wel lheed, AH-20 }\end{array}$ & 98.4 & -- & -- & 62.70 & 69.6 & $<0.249$ & $<0.178$ & 0.177 & 28.2 & $<0.099$ & 0.0035 & $<0.008$ & 98.98 & -6.56 \\
\hline$E L S-30^{\circ}$ & $4 / 18 / 88$ & $\begin{array}{l}\text { Well AH-22; downhole } \\
\text { sampler, } 650 \mathrm{~m}\end{array}$ & $<70.0$ & -- & --- & 91.00 & 87.3 & 0.024 & -- & --- & -- & 0.046 & $\begin{array}{c}2.41 \\
\cdots\end{array}$ & 0.013 & 99.99 & -3.70 \\
\hline ELS-31 & $4 / 19 / 88$ & $\begin{array}{l}\text { Woll AH-22; cyclone } \\
\text { soparator }\end{array}$ & 107.2 & 0.208 & 619 & 2.43 & 90.7 & 1.76 & 0.683 & 0.042 & 6.63 & $<0.074$ & 0.082 & $<0.074$ & 99.88 & -5.02 \\
\hline ELS-32 & $4 / 19 / 88$ & $\begin{array}{l}\text { Well AH-22; } \\
\text { wober separator }\end{array}$ & 136.0 & 0.160 & 2108 & 0.28 & 96.9 & 0.787 & 0.097 & 0.011 & 1.89 & $<0.016$ & 0.232 & $<0.016$ & 99.93 & -3.04 \\
\hline
\end{tabular}

Analyses ELS-22, ELS-23, and ELS-30 by W. Evans, USGS, Menlo Park, Callifornia; all others by Thermochom, Santa Rosa, California.

Isotope onalyses of ELS-22, ELS-23, and ELS-30 by D. Whito, USGS, Menlo Park, California; all others by C. Jenik, USGS, Monlo Park, California.

CAnalysis for ELS-22 includos 0.003 volx $\mathrm{C}_{2} \mathrm{H}_{6}$ and $0.050 \mathrm{volx} \mathrm{CO}$; Ill Ar and $\mathrm{N}_{2}$ assumed to be air contamination.

Analysis for ELS-23 includes 0.015 volx $\mathrm{C}_{2} \mathrm{H}_{6}$ and 0.245 volx $\mathrm{CO}$; 111 Ar and $\mathrm{N}_{2}^{2}$ assumed to be air contamination.

Analysis for ELS-30 included 0.202 volX CO; all Ar and $\mathrm{N}_{2}$ assumed to be air contamination.

femporature of separation or temporature of extraction from sample bottlo. 


\section{Geothermal Well Variations}

Some unusually interesting variations in brine chemistry are displayed in Figs. 37 through 40. For example, a casual look at a plot of $\mathrm{Na}$ versus $\mathrm{Cl}$ (Fig. 37) shows that an excellent mixing relation exists between various geothermal brines and cold, meteoric water. More importantly, several wells show variations with respect to depth with the deeper in situ sample being more concentrated than the shallower in situ sample (compare AH-1; $1100 \mathrm{~m}$, to AH-1, $550 \mathrm{~m}$ ). In addition, total flow samples (collected from the weirbox) generally are less concentrated than in situ samples collected from deeper levels of a given well (AH-1, AH-22, and AH-27). All interpretations of total flow samples are based on flash-corrected analyses.

A summary of "natural state" conditions in the Ahuachapan geothermal field and changes in reservoir processes caused by production has recently been reported by Truesdell et al. (1989) and Steingrimsson et al. (1989). These authors state that $\mathrm{Cl}$ content and temperature of the west part of the field were originally about $9000 \mathrm{mg} / \mathrm{kg}$ and $265^{\circ} \mathrm{C}$, whereas $\mathrm{Cl}$ content and temperature in the east part of the field were originally $6000 \mathrm{mg} / \mathrm{kg}$ and $235^{\circ} \mathrm{C}$. They also state that breakthrough of cooler, less saline water has occurred in the reservoir as reservoir pressures have declined as much as 15 bars due to production (e.g., Truesdell et al., 1989, Fig. 4).

Our data clearly show that a less saline water is diluting the top of the geothermal reservoir at wells $A H-1, A H-22$, and AH-27. For example, total flow of $\mathrm{AH}-1$ must be from the general vicinity of $550 \mathrm{~m}$ (Fig. 37) even though a more concentrated fluid occurs at $1100 \mathrm{~m}$. For some reason the lower, more concentrated horizon is less productive (permeable) than the upper, diluted zone. Total flow samples of wells $\mathrm{AH}-22$ and $\mathrm{AH}-27$ are less concentrated than fluids at only modest depths $(650 \mathrm{~m}$ and $725 \mathrm{~m}$, respectively). Evidently, diluted reservoir fluids are easier to produce than more concentrated fluids at deeper levels. The same basic relations are shown in plots of $\mathrm{B}$ versus $\mathrm{Cl}$, As versus $\mathrm{Cl}$, and $\mathrm{Ca}$ versus $\mathrm{Cl}$ (Figs. 38, 39, and 40), although the latter two plots are not as clearly defined. As and $\mathrm{Ca}$ are both less conservative, and irregular variations in $\mathrm{Ca}$ versus $\mathrm{Cl}$ may also reflect other reservoir processes such as boiling and precipitation of calcium carbonate $\left(\mathrm{CaCO}_{3}\right)$. 


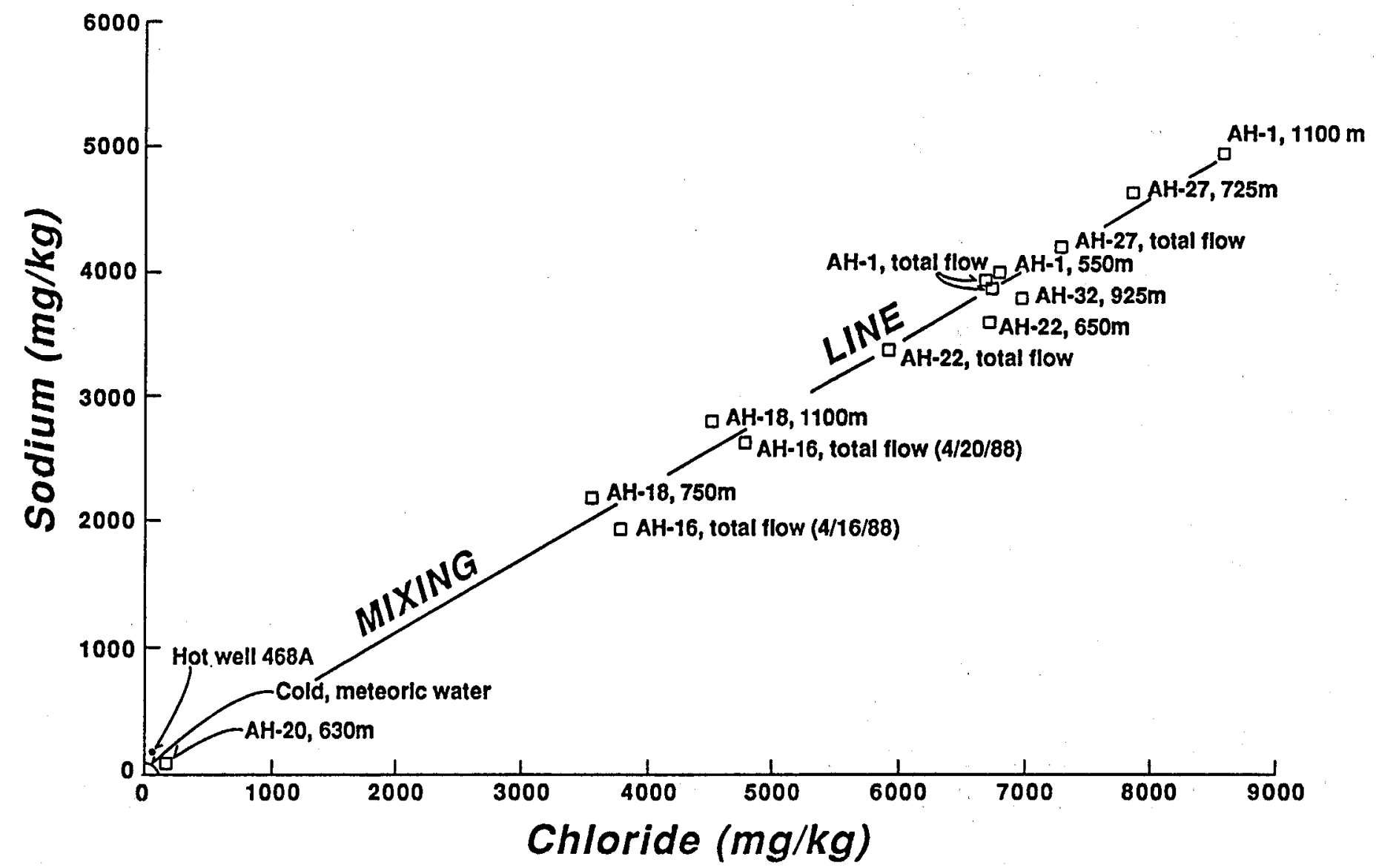

Fig. 37. Plot of $\mathrm{Na}$ versus $\mathrm{Cl}$ for fluid samples (corrected for steam flash where appropriate), Ahuachapán, El Salvador; boxes are geothermal well samples; dots are all other samples. 


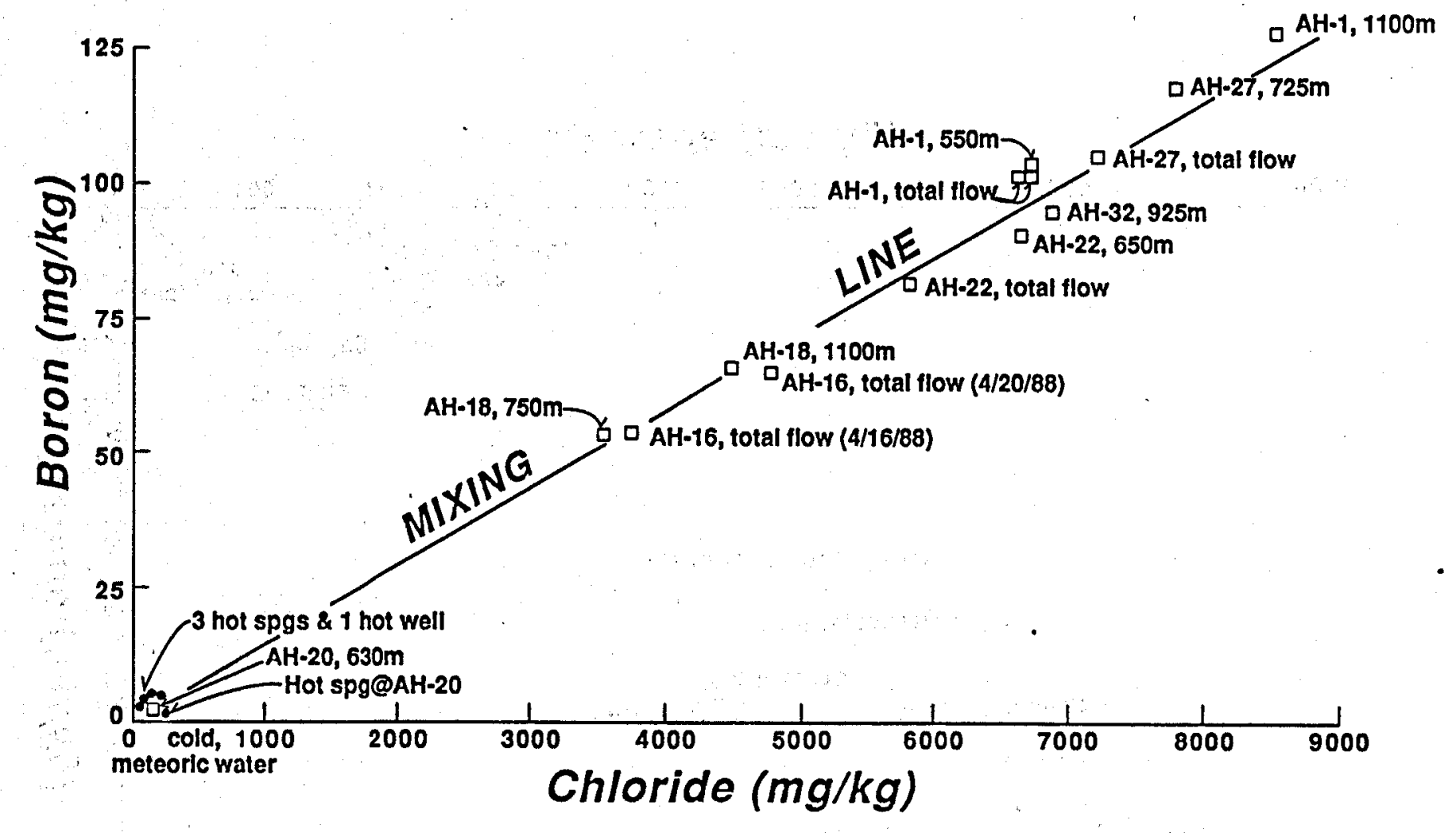

Fig. 38. Plot of B versus $\mathrm{Cl}$ for fluid samples (corrected for steam flash where appropriate), Ahuachapán, EI Salvador; symbols same as Fig. 37. 


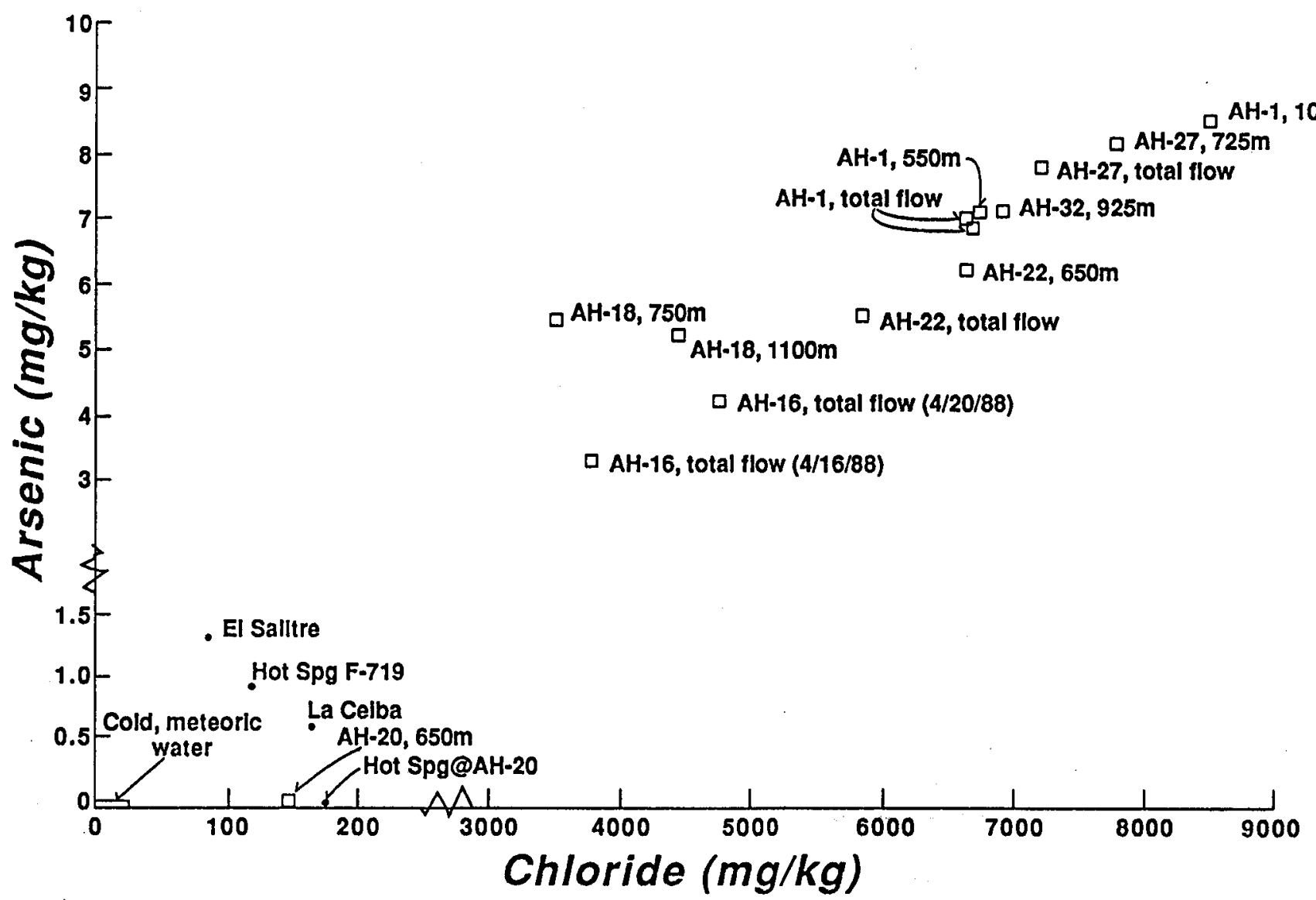

Fig. 39. Plot of As versus Cl for fluid samples (corrected for steam flash where appropriate), Ahuachapán, El Salvador; symbols same as Fig. 37; note split scale on both axes. 


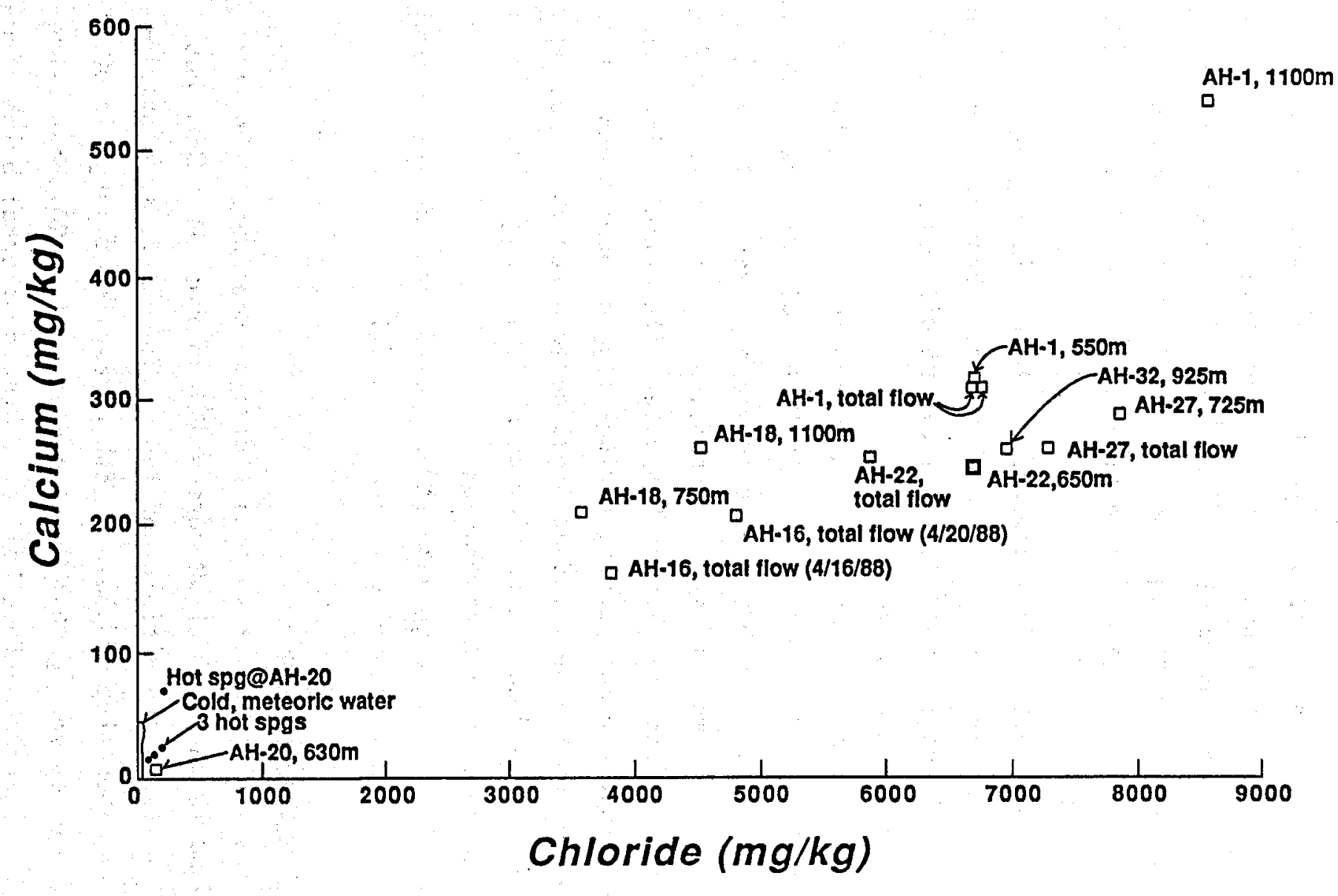

Fig. 40. Plot of $\mathrm{Ca}$ versus $\mathrm{Cl}$ for fluid samples (corrected for steam flash where appropriate), Ahuachapán, El Salvador; symbols same as Fig. 37. 
The general pattern of increasing concentration with depth in a well is also displayed by two in situ samples from well AH-18; however, the concentration of both horizons is so low compared with other wells that yet another process is suggested. According to CEL records and our well logs, wells $A H-16$ and AH-18 are nonproductive and produce only vapor. Our data suggest that both wells are extremely impermeable. When opened, the wells produce steam from boiling in the aquifer. Production of steam and a restricted amount of reservoir fluid at a given horizon produces the relatively dilute fluids observed.

An alternative explanation is suggested by the chemical geothermometry of Table VII. Chemistry of well AH-18 fluids shows equilibration at much lower temperatures. Thus fluids in AH-18 could merely be diluted by as much as $50 \%$ with cooler, less saline groundwater.

Well AH-20 has a major leak at the point where the liner is hung from the casing (400 $\mathrm{m}$ depth). This problem must affect the well to greater depths because our in situ sample from $630 \mathrm{~m}$ is composed of essentially dilute, nearsurface groundwater. The most anomalous constituent is relatively high $\mathrm{Ca}$, which probably results from reaction of hot water with cement. Presumably this water was injected into the well during various logging operations. A new set of hot springs formed on the well pad at AH-20 between our two sampling trips. Clearly, the cement job and casing problem at AH-20 are bad. Data from well AH-20 have not been used for interpretation.

No data (AH-19) or not enough data (AH-32) eliminate any interpretation of unique reservoir processes occurring in these two wells.

\section{Recharge to Ahuachapán System}

Stable isotope variations of various fluids of the Ahuachapán area (Table VII) can be studied in the plot of $\delta D$ versus $\delta^{18} 0$ of Fig. 41. Both hot and cold springs and wells in the vicinity of the geothermal field plot close to the world meteoric water $l i n e$ and have a rather restricted range in $\delta 0$ of -48 to $-52 \%$. The new hot spring that developed at well AH-20 shows extreme evaporation due to vigorous surface boiling. Deep geothermal brines from in situ samples display a rather small range in $6 D$ of -43 to $-53^{\circ} \%$ (if we ignore the sample AH-27 at $725 \mathrm{~m}$, which appears to be a bad analysis). In 
TABLE VII. ISOTOPIC DATA ON WATERS FROM SPRINGS AND WELLS, AHUACHAPAN, EL SALVADOR*

\begin{tabular}{|c|c|c|c|c|c|c|c|}
\hline Sample No. & Description & $\begin{array}{l}80 \\
(\% / 00)\end{array}$ & $\begin{array}{c}\delta^{18} 0 \\
(\% / 00)\end{array}$ & $\begin{array}{c}\left.\delta^{13} \mathrm{C}_{\left(\% \mathrm{CO}_{3}\right)}\right) \\
(\% / 00)^{3}\end{array}$ & $\begin{array}{c}\delta^{18} \mathrm{O}\left(\mathrm{SO}_{4}\right) \\
(\% \circ 0)\end{array}$ & $\begin{array}{c}{ }^{\mathbf{B}_{H}} \\
\text { (T.U.) }\end{array}$ & $\underset{(\mathrm{mg} / \mathrm{kg})}{\mathrm{Cl}^{\mathrm{b}}}$ \\
\hline \multicolumn{8}{|c|}{ Miscellineous Samples } \\
\hline ELS-9 & El Salitre Hot Spring & -51.3 & -7.14 & -5.80 & 2.74 & 4.27 & 87.4 \\
\hline ELS-10 & La Coiba Hot Spring & -51.5 & -7.23 & -- & --- & 2.63 & 165 \\
\hline ELS-12 & Unnamed Cold Spring & -48.6 & -6.73 & -- & --- & 5.44 & 3.2 \\
\hline ELS-14 & Rainwater & -15.2 & -3.55 & -- & --- & 12.1 & 17 \\
\hline ELS-19 & $\begin{array}{l}\text { Cold Spring, } \\
\text { Finca La Victoria }\end{array}$ & -51.8 & -7.68 & --- & -- & 5.07 & 2.0 \\
\hline ELS-27 & Hot Spring $F-719$ & -50.6 & -7.30 & -- & 3.88 & 2.48 & 120 \\
\hline ELS-29 & Springs at $A H-20$ & -19.1 & +4.18 & --- & --- & --- & 177 \\
\hline \multicolumn{8}{|c|}{ Geothermal and Other Wells } \\
\hline ELS-1 & Well $A H-1$, in situ & -47.8 & -3.68 & --- & 2.32 & 48.3? & 8590 \\
\hline ELS-3 & Well AH-1, weirbox & -40.7 & -2.82 & --- & --- & -- & 6685 \\
\hline ELS-4 & Well AH-1, weirbox & -39.0 & -2.81 & -- & 2.32 & 1.66 & 6700 \\
\hline ELS-E & Woll AH-1, in situ & -43.4 & -3.89 & -- & --- & -- & 6760 \\
\hline ELS-7 & Well AH-27, weirbox & -39.1 & -2.39 & -- & 2.02 & 0.98 & 7250 \\
\hline ELS-8 & Well AH-27, in situ & -57.2 & -3.78 & -- & 1.00 & $5.79 ?$ & 7820 \\
\hline ELS-13 & WEII AH-20, in situ & -52.8 & -7.31 & -5.40 & 2.29 & 6.36? & 148 \\
\hline ELS-16 & Woll $\mathrm{AH}-18$, in situ & -46.4 & -3.87 & $\cdots$ & 2.86 & $4.85 ?$ & 4500 \\
\hline ELS-17 & Well $A H-18$, in situ & -48.5 & -3.04 & -- & -- & $4.98 ?$ & 3530 \\
\hline ELS-22 & Well AH-32, in situ & -45.4 & -3.85 & $\cdots$ & --- & --- & 6930 \\
\hline ELS-23 & Well AH-16, in situc & -44.3 & -4.36 & -- & -- & -- & -- \\
\hline ELS-24 & Well AH-16, weirbox & -26.5 & -1.44 & -- & 4.41 & 0.28 & 3770 \\
\hline ELS-25 & Cold well 438 & -52.5 & -7.57 & -13.4 & 6.89 & 3.25 & 10.5 \\
\hline ELS-26 & Cold woll 385 & -50.0 & -7.22 & $\cdots$ & --- & --- & 24.9 \\
\hline ELS-28 & Hot well $468 \mathrm{~A}$ & -48.6 & -7.09 & -- &.-- & 3.58 & 62.0 \\
\hline ELS-30. & Well AH-22, in situ & -45.6 & -4.22 & $\cdots$ & 2.26 & 1.29 & 6670 \\
\hline ELS-31 & Well AH-22, cyclone & -53.4 & -6.85 & --- & --- & -- & 10.7 \\
\hline ELS-32 & Well AH-22, condensate & -37.5 & -4.27 & -- & $\cdots$ & $\cdots$ & 84.8 \\
\hline ELS-33 & Well AH-22, water & -41.8 & -3.60 & -- & -- & 0.70 & 5880 \\
\hline ELS-34 & Well AH-16, condensate & -40.1 & -3.22 & $\cdots$ & -- & --- & -- \\
\hline ELS-35 & Well $A H-16$, water & -43.1 & -2.80 & $\cdots$ & -- & -- & 4780 \\
\hline
\end{tabular}

Deuterium and oxygen-18 in water by J. Borthmick, Southern Methodist University; carbon-13 $\left(\mathrm{HCO}_{3}\right)$ and oxygen-18 $\left(\mathrm{SO}_{4}\right)$ by $\mathrm{C}$. Janik, USGS; tritium by H.G. Ostlund, University of Miami.

bhloride values listed are corrected for stean flash where appropriate.

csample bottle did not fill adequately for unknown reason; thus sample may be unreliable. 


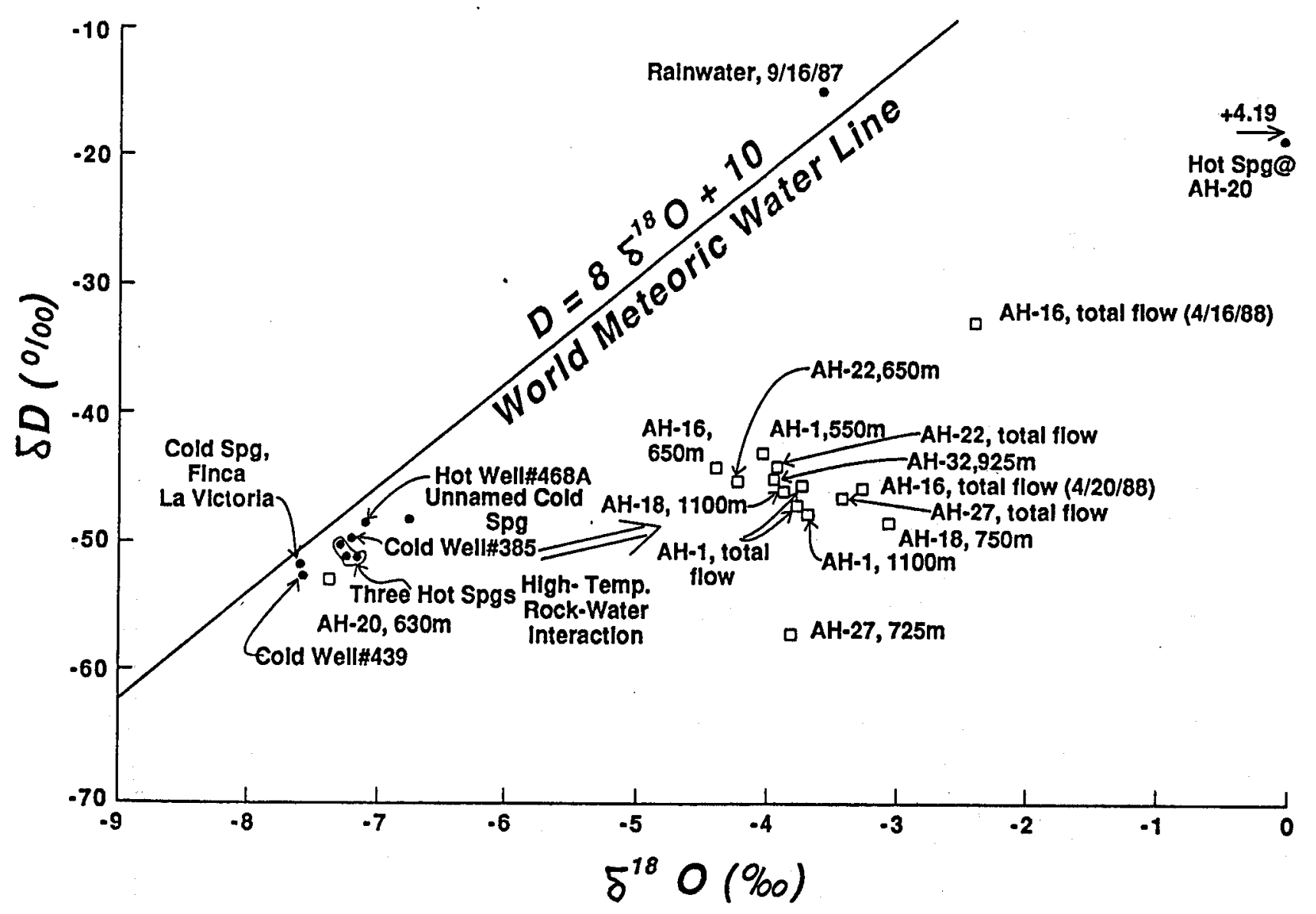

Fig. 41. Plot of $\delta D$ versus $\delta^{18} 0$ for fluid samples (corrected for steam flash where appropriate), Ahuachapán, EI Salvador; symbols same as Fig. 37. 
general, the data suggest that the Ahuachapan reservoir is relatively. homogeneous and has a source of recharge similar to but possibly lower in elevation than local, near-surface groundwaters. We state this because the deuterium values of reservoir water are heavier than local meteoric water. We do not have enough data from cold springs in the highlands south of the geothermal field to make firmer statements. In addition, the stable isotopes of the deep reservoir fluids suggest that subtle differences'occur in the isotopes of individual horizons that cannot be explained by simple mixing processes. Nonetheless, the cluster of reservoir points is shifted to the right of the local meteoric cluster indicating that 1) recharge is fairly localized and 2) significant oxygen-18 exchange has occurred between water and rock in a high-temperature environment. 0xygen-18 shifts of 2 to as much as $12 \%$ are characteristic of geothermal reservoirs $>200^{\circ} \mathrm{C}$, and the 3.5 to $4^{\circ} \%$ o shift of Ahuachapán fluids is quite typical.

No clear relation can be seen between total flow and in situ samples from the same well or between the isotope values and other chemical constituents of all well samples. For example, the total flow samples from well AH-1 isotopically resemble the in situ sample of AH-1 at $1100 \mathrm{~m}$. Recall that, chemically, total flow samples from $A H-1$ resemble the in situ sample of $A H-1$ at $550 \mathrm{~m}$. The sample from well AH-1 at $1100 \mathrm{~m}$ has the highest $\mathrm{Cl}$ content of any of the samples we collected, yet, isotopically, well AH-27 (total flow) appears to have fluids that are "heavier" with respect to oxygen-18. Samples from wells $A H-16$ and AH-18 show great scatter probably resulting from the low permeability and erratic performance characterizing these wells.

Again, we note that the fluid produced from $630 \mathrm{~m}$ in well AH-20 is not reservoir fluid because it isotopically resembles local meteoric water, not reservoir water. Note also, that the sample of rainwater (collected during a storm at well AH-18) is not at all typical of local groundwater, having a $6 D$ of $-15^{\circ} / 0_{0}$. Possibly, the sample represents a storm of abnormal composition. If this sample is reliable, it would mean that recharge to the Ahuachapan system comes from exceptionally high elevations. The mountains south of the geothermal field are a logical recharge point, but even so the single rainwater sample seems unusually enriched with respect to $\delta^{18} 0$. 


\section{E. Relative Age of Geothermal Waters}

Tritium is useful for estimating relative ages of water because it has a short half-life of $12.43 \mathrm{yr}$ and was produced in copious amounts during the fifties and early sixties. Tritium variations of all fluid types with respect to $\mathrm{Cl}$ can be seen in Fig. 42. Goff et al. (1987b) have determined that present meteoric precipitation in Central America averages between 2 to 5 T.U. Again, the rainwater sample is extremely anomalous because it has $>12$ T.U.; thus the rain of 9/16/87 represents a storm of unusual isotopic composition. Hot and cold springs and dilute wells show typical tritium variations of about 2.5 to 5.5 T.U. indicating they are composed mostly of relatively young water. A normal variation of decreasing tritium content with increasing $\mathrm{Cl}$ content is suggested by the three hot spring samples.

Because most $\mathrm{Cl}$ is contributed from reservoir fluids, which are presumably relatively old, reservoir fluids should be low in tritium. Unfortunately, nearly all data obtained from in situ samples are unreliable (4.8 to >48 T.U.!!) indicating that the tool was fabricated in a contaminated location or from contaminated steel. Total flow samples contain relatively low tritium levels ( $<1.7$ T.U.), but even most of these values are unusually high compared with tritium levels in most geothermal fields (typically <0.5 T.U.). For example, tritium levels at Platanares, Honduras, are 0.2 to $0.4 \mathrm{~T} . \mathrm{U}$. , and levels at Miravalles, Costa Rica, are <0.3 T.U. The only Ahuachapán sample with low tritium comes from well AH-16 (0.29 T.U.). Higher tritium in other well samples suggests some encroachment of relatively young water into reservoir fluids.

Using a semiquantitative model for tritium input as a function of time, Pearson and Truesdell (1978) developed equations for estimating the age of water from its tritium content assuming two types of reservoir cases: pistonflow and well-mixed. C. O. Grigsby in Goff et al. (1987b) derived analytical solutions for both reservoir types for Central American tritium input levels. Most geothermal systems are best approximated as well-mixed reservoirs. If we assume that the tritium level of AH-16 (0.29 T.U.) is representative of uncontaminated reservoir fluid, the indicated mean age of water in the reservoir is about $700 \mathrm{yr}$ (Table VIII). 


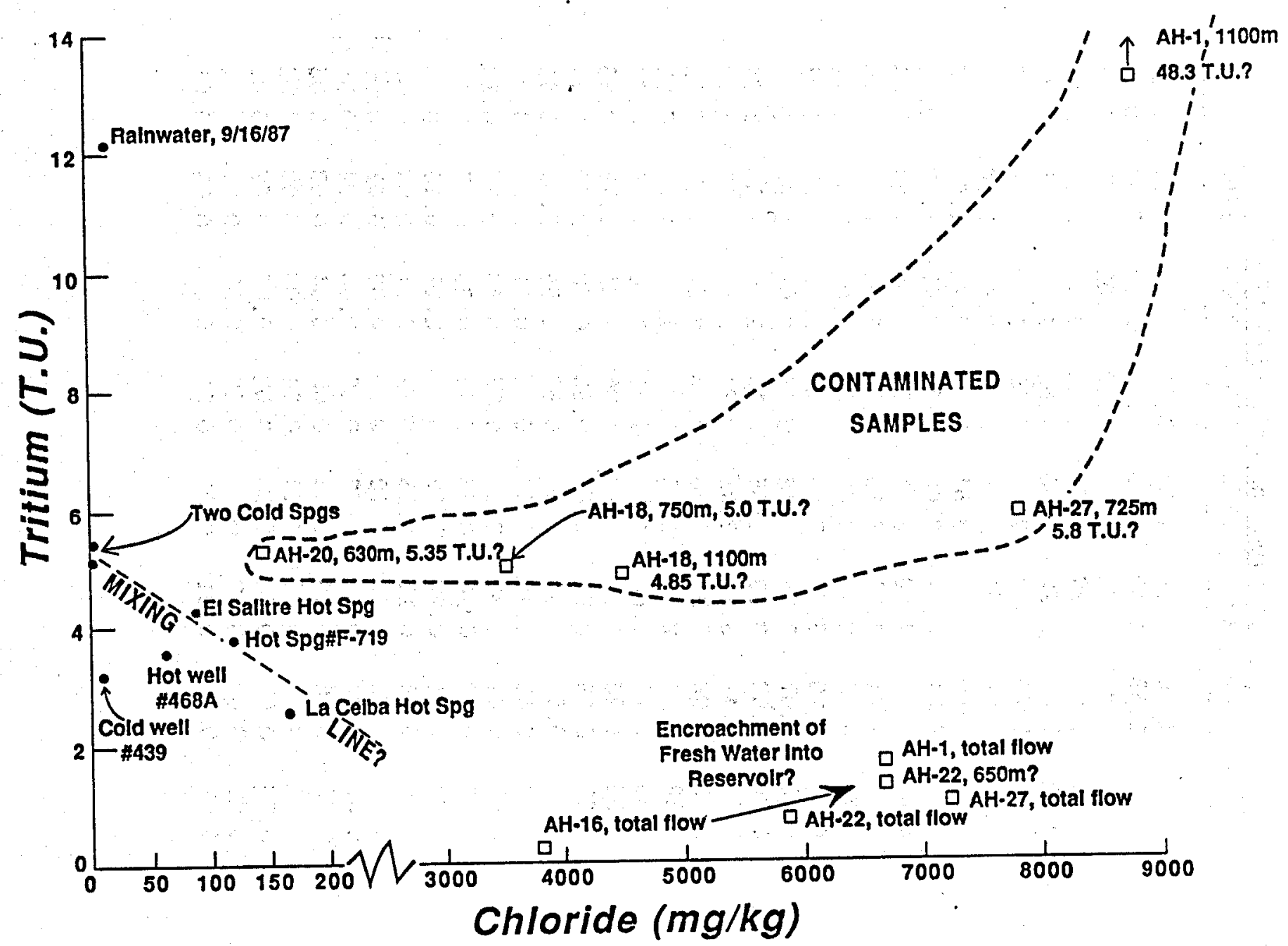

Fig. 42. Plot of ${ }^{3} \mathrm{H}$ versus $\mathrm{Cl}$ for fluid samples (corrected for steam $\mathrm{flash}$ where appropriate), Ahuachapán,. El Salvador; symbols same as Fig. 37; note split scale of $\mathrm{Cl}$ axis. 
TABLE VIII. TRITIUM CONCENTRATION AND RESIDENCE TIMES FOR SELECTED BASE YEARS IN CENTRAL AMERICA, WELL-MIXED CASE (from Goff et al., 1988)

Residence Time $\tau(y r)$

1.0

2.0

3.0

4.0

5.0

7.5

10.0

12.5

15.0

17.5

20.0

22.5

25.0

27.5

30.0

40.0

50.0

75.0

100.0

150.0

200.0

300.0

400.0

500.0

750.0

1000.0

1500.0

2000.0

3000.0

4000.0

5000.0

7500.0

10000.0

15000.0
Tritium Concentration (T.U)

$\begin{array}{llllllll}1985 & 1986 & 1987 & 1988 & 1989 & 1990 & 1995 & 2000\end{array}$

$1.70 \quad 1.46$

$1.91 \quad 1.63$

$1.25 \quad 1.07$

0.92

0.79

0.37

0.17

$2.19 \quad 1.88$

1.61

1.20

1.03

0.88

0.41

0.19

$2.58 \quad 2.21$

$3.02 \quad 2.59$

1.89

1.61

1.18

1.28

2.22

1.90

1.63

1.18

0.47

0.22

4.01

3.49

3.04

2.64

2.30

1.40

0.55

0.25

3.61

3.19

3.51

4.91

4.09

3.93

5.00

4.07

3.66

2.81

1.99

0.65

0.30

3.13

3.30

2.48

2.79

2.97

0.98

0.47

$4.51 \quad 4.09$

3.71

4.86

4.44

4.05

3.69

3.36

3.05

3.37

3.06

3. 33

3.04

3.26

2.99

1.30

0.67

4.57

4.20

3.86

3.55

3.75

3.46

4.24

3.66

4.07

3.63

3.17

3.35

3.41

2.98

2.38

2.24

2.78

2.95

2.60

2.10

1.98

1.68

1.58

1.26

1.19

1.13

3.18

3.10

2.74

2.43

1.86

1.49

1.06

1.03

0.98

0.92

0.87

0.83

0.64

0.60

0.57

0.44

0.35

0.39

0.46

0.41

0.28

0.26

0.37

0.25

0.24

0.18

0.20

0.19

0.14

0.15

0.11

0.13

0.13

0.12

$0.10 \quad 0.10$

0.09

0.07

0.07

0.06

0.05

0.07

0.06

0.06

0.05

0.05

0.05

0.04

2.93

2.86

2.55

2.27

1.74

1.40

1.01

0.78

0.54

0.41

0.33

0.23

0.17

0.11

0.09

0.06

1.55

0.85

1.73

0.99

1.84

1.09

1.90

1.16

$0.04 \quad 0.04$

$0.03 \quad 0.03$

$\begin{array}{ll}0.02 & 0.02\end{array}$

0.01

0.03

0.02

0.02

0.01

0.01

0.02

0.02

0.01

0.04

0.03

0.02

0.02

0.01
1.93

1.93

1.92

1.90

1.75

1.59

1.26

1.03

0.75

0.59

0.41

0.31

0.17

0.13

0.09

0.07

0.04

0.03

0.03

0.02

0.01
0.01

1.21

1.23

1.24

1.24

1.19

1.11

0.90

0.75

0.56

0.44

0.31

0.24

0.19

0.13

0.10

0.07

0.05

0.03

0.03

0.02

0.01

0.01

0.01
0.25 


\section{F. Sources of Carbon}

The $\delta^{13} \mathrm{C}\left(\mathrm{CO}_{2}\right)$ values of Ahuachapán geothermal gases are listed in Table VI. Except for two samples of dubious analytical quality the values range between -6.5 and $-2.0 \%$ with an average of $-4.01 \pm 1.3 \%$. Fumarole samples have a similar average of $-3.68 \pm 0.4 \%$. These values are slightly heavier than the range of values usually reported for "mantle" carbon ( -5 to $-8 \%$; Hoefs, 1973) and suggest that at least part of the carbon species comes from thermal decarbonation of limestone (Goff et al., 1985). Possibly limestones occur in the volcaniclastic rocks that partially constitute the Ahuachapán reservoir (Laky et al., 1989). A pure mantle or magmatic source for the carbon is not justified by the data.

\section{G. Chemical Geothermometry}

Calculated subsurface equilibration temperátures using a suite of widely used chemical geothermometers are shown in Table IX. As mentioned above, because of the low gas pressures associated with most Ahuachapan fluids and their relatively low concentrations of $\mathrm{H}_{2} \mathrm{~S}, \mathrm{H}_{2}$, and $\mathrm{CH}_{4}$, gas geothermometers could not be calculated for many samples. Most of the values given are minimum estimates. The empirical gas geothermometer of Norman and Bernhardt (1981) uses only the ratio of $\mathrm{CH}_{4} / \mathrm{CO}_{2}$. Where the data allow exact calculations, the estimated temperatures are about $10^{\circ}$ to $20^{\circ} \mathrm{C}$ higher than measured temperatures. The empirical gas geothermometer of D'Amore and Panichi (1980) uses the compositions of $\mathrm{CO}_{2}, \mathrm{H}_{2} \mathrm{~S}, \mathrm{CH}_{4}$, and $\mathrm{H}_{2}$ in a rather complex equation. Estimated temperatures are about the same or $10^{\circ} \mathrm{C}$ lower than measured temperatures.

Quartz, $\mathrm{Na}-\mathrm{K}$ (Fournier), and $\mathrm{Na}-\mathrm{K}-\mathrm{Ca}(\beta=1 / 3)$ temperatures are generally within $10^{\circ}$ to $15^{\circ} \mathrm{C}$ of each other for a given well. The Na-K (Fournier) equation of ten overpredicts temperatures by a few degrees, whereas quartz temperatures may be slightly low due to precipitation of silica. The sulfateisotope geothermometer predicts slightly high values (depending on assumptions) compared with measured temperatures, whereas the $\mathrm{Na}-\mathrm{Li}$ geothermometer overpredicts temperatures by $100^{\circ} \mathrm{C}$.

Measured temperatures in wells logged by LANL range from about $215^{\circ} \mathrm{C}$ (well AH-22) to $255^{\circ} \mathrm{C}$ (well AH-18). In most cases the geothermometers indicate a fairly consistent equilibration temperature that is slightly higher than the 


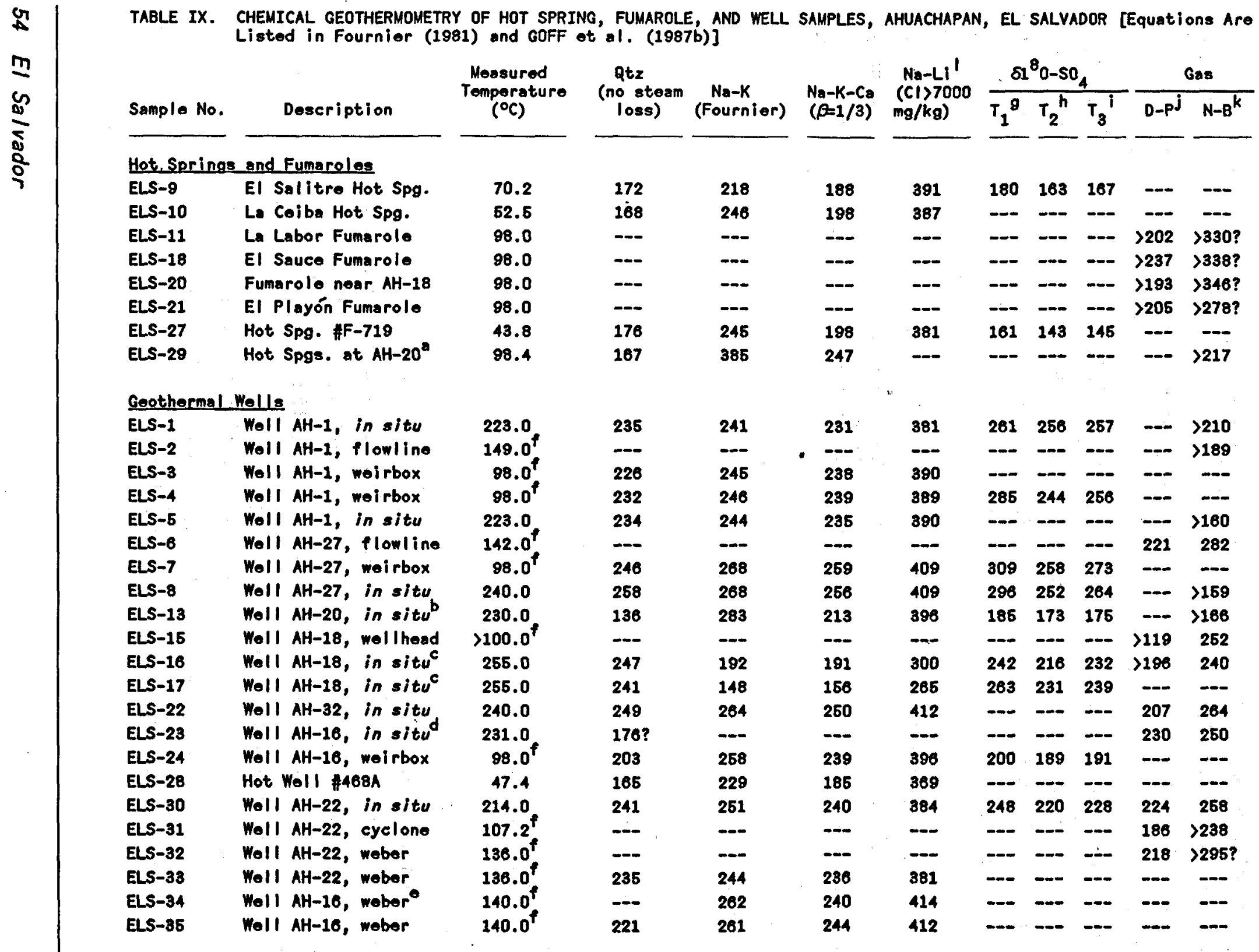


TABLE IX (continued)

aprings have apparently formed due to a loak in casing of AH-20; goothermomotry from water analysis is not considered valid.

bWoll logging indicates leak in casing at $400 \mathrm{~m}$ depth; sample is very dilute comparod with other doop goothermal waters; geothermomotry from water analysis not considered valid.

CWoll is nonproducer and supposedly contains vapor only; chemical anslysis is rather concentrated but has odd Na/K ratio; goothermometry from water analysis not considered valid.

Sample bottle did not fill adequately for unknown resson.

-Samplo is supposedly steam condensate from weber separator, but analysis indicates $360 \%$ brine carry-over.

Temperature of steam separation during sampling operations.

9 No stoum loss.

haximum stean loss.

iContinuous storm loss.

jo'Amore and Panichi (1980).

Korman and Bornhardt (1981).

'Fouillac and Michard (1981). 
measured temperature (wells $A H-1, A H-16, A H-22, A H-27$, and $A H-32$ ). This would be consistent with encroachment of reservoir fluid by a cooler, dilute fluid or with slight amounts of conductive cooling if the well location is downstream of the upflow zone of the reservoir.

In one case (well $\mathrm{AH}-18$ ), the measured temperature $\left(255^{\circ} \mathrm{C}\right.$ ) is slightly higher than quartz values (about $245^{\circ} \mathrm{C}$ ) and significantly higher than cation values $\left(150^{\circ}\right.$ to $\left.190^{\circ} \mathrm{C}\right)$. This can result only from a process that causes reequilibration of the fluid; dilution alone cannot cause this type of behavior. Because AH-18 is a nonproducer and behaves like an excess enthalpy well, precipitation of minerals in the formation may cause fluid re-equilibration. Judging from the $\mathrm{Ca}$ versus $\mathrm{Cl}$ plot, calcite is not precipitated because AH-18 fluids are relatively Ca-rich. On the other hand, $K$ is extremely depleted relative to $\mathrm{Cl}$ (Table IV); thus, it appears that a K-rich mineral is precipitating. The best candidate is adularia, a common K-rich mineral precipitated during boiling.

Fluid from well AH-20 has already been shown to be almost entirely nearsurface groundwater; thus, chemical geothermometers are meaningless for this fluid.

\section{H. Downhole Fluid Composition of $\mathrm{AH}-1$ and $\mathrm{AH}-27$}

Because of the consistently high indicated reservoir temperatures of wells $A H-1$ and $A H-27\left(240^{\circ}\right.$ and $260^{\circ} \mathrm{C}$, respectively) and their correspondingly high Cl contents at deeper levels (e.g., Fig. 37), these two wells (of the seven that were sampled) are considered to contain fluids most representative of uncontaminated brine. As a result, gas and fluid compositions have been reconstructed for the deeper in situ samples of these wells (Table $X$ ). Values listed for $\mathrm{H}_{2} \mathrm{~S}$ and $\mathrm{H}_{2}$ may be too low and too high, respectively, for reasons discussed above. From examination of the data in Table VI, our preferred values for $\mathrm{H}_{2} \mathrm{~S}$ and $\mathrm{H}_{2}$ are about $1 \mathrm{mg} / \mathrm{kg}$ and $0.01 \mathrm{mg} / \mathrm{kg}$, respectively. 
TABLE $X$. CALCULATED DOWNHOLE COMPOSITIONS OF THE TWO MOST CONCENTRATED HORIZONS SAMPLED DURING THIS PROJECT, AHUACHAPAN, EL SALVADOR (AII Values in $\mathrm{mg} / \mathrm{kg}$ Except Where Noted)

Well

Physical Data

Sample No.

Date

Dopth of sample, in

Collection temperature, ${ }^{\circ} \mathrm{C}$

Equil. temperature, oc

Sample woight, g

Internal pressure, atm

Gas extracted, moles

Temperature of extraction, ${ }^{\circ} \mathrm{C}$

Number of gas extractions

Major Eloments

$\mathrm{SiO}_{2}$

As

Ca

$\mathrm{Mg}$

Sr

$\mathrm{Na}$

$\mathrm{K}$

Li

$\mathrm{HCO}_{3}$

$\mathrm{CO}_{3}$

$\mathrm{Fo}^{\mathrm{S}}$

CI

Br

B

Trace Elements ${ }^{b}$

Ba

Cs

Fo

Un

Mo

$\mathrm{NH}_{4}$

Zn

Gases

$\mathrm{CO}_{2}$

$\mathrm{NH}_{3} \mathrm{C}$

Ar ${ }^{3}$

$\mathrm{CH}_{4}$ c

$\mathrm{H}_{2}$

$\mathrm{CO}^{\mathrm{c}}$
AH-1

ELS-1

9/11/87

1100

223

235-240

3416

0.232

0.011

60

3

411

8.3

649

0.31

5.32

4890

650

14.6

31.7

0

30.1

0.85

8580

25.6

126

0.49

2.52

1.20

1.61

0.05

0.60

4.24

0.02

119.5

$0.02^{d}$

0.01

0.14

11.4

0.02

$0.14^{\circ}$

0.002

0.18

새-27

ELS-8

9/13/87

725

240

255-260

3130

0.156

0.0076

65

2

633

8.0

293

0.16

2.96

4880

800

16.1

46.1

0

22.4

1.04

7820

23.4

118

0.62

2.30

0.07

0.13

0.03

0.50

4.94

$<0.02$

94.4

$0.02^{d}$

0.01

0.09

6.38

0.02

0.01

0.001

0.14

Based on chemical geothermometry (Table VII).

Many other elements below detection limit (Table III).

Estimated by comparison with other in situ analyses (Table IV).

dValue probably too low from reaction of $\mathrm{H}_{2} \mathrm{~S}$ with stainless steel.

eValue probably too high from reaction of $\mathrm{H}_{2} \mathrm{O}$ with stainless steel. 


\section{ACKNOWLEDGMENTS}

We thank J. C. Chávez and the CEL field teams for their hard work, dedication, and cooperation with the geochemical sampling program and the well logging operations. H. G. Ostlund, University of Miami, performed the tritium analyses; J. Borthwick, Southern Methodist University, analyzed the stable isotopes. Thermichem, Santa Rosa, California, and W. Evans, US Geological Survey, Menlo Park, performed the gas analyses. This project was funded by the US Department of State, Agency for International Development.

The Los Alamos field teams, Benny Garcia, Ray Jermance, Jerry Kolar, Richard Maestas, and AI Marquez all from SST-11; Joe Kurtenbach, MEC-5; Ken Joy, EES-DO; and Robert Hendron, EES-DOT, are recognized for the successful logging operations in the severe borehole environments. 


\section{APPENDIX A}

\section{GEOTHERMAL WELL LOGGING EQUIPMENT}

The Los Alamos National Laboratory (with funding provided by AID) furnished a new logging truck for the Central American geothermal energy program, complete with auxiliary generators, a data acquisition system, hydraulic-powered draw works, and associated controls.(Fig. A-1). The draw works are equipped with $3,000 \mathrm{~m}(10,000 \mathrm{ft})$ of armored cable that contains seven electrical conductors with TFE Teflon insulation. The cable armor package is improved galvanized plow steel, and the cable is rated for continuous service at temperatures up to $320^{\circ} \mathrm{C}$.

Los Alamos also equipped the logging truck with the wellhead apparatus required to "rig up" for deployment of the downhole instrument. (The downhole instrument is commonly referred to as the logging tool.) This apparatus includes the upper and lower sheaves, pressure lock with cooling jacket, Bowan control head (pack-off), and cable cooling system. All downhole instrument systems were designed, fabricated, and tested at the Los Alamos National Laboratory. The set of logging tools consists of cableheads, a temperature probe with a casing collar locator (CCL) and ring gauge, a downhole fluid sampler, and a fluid velocity (spinner)/temperature/pressure tool (STP).

The cablehead (Fig. A-2) is designed specifically for long-term operation in a geothermal environment where fluid temperatures exceed $300^{\circ} \mathrm{C}$. The cablehead permits termination of the seven-conductor armored cable; it completes the transition of the logging tool while ensuring watertight integrity in the high-temperature and high-pressure geothermal fluids. The cablehead can be disconnected from the armored cable should the tool become stuck in the well lbore.

Borehole temperature surveys are used to determine thermal gradients along the borehole under both static and flowing conditions. Temperature anomalies in regions where fluid flows into or out of the borehole are easily detected, so that fracture intersections or perhaps damaged casing can be located. The temperature tool includes the $\mathrm{CCL}$ to detect casing signatures to correct tool depth, which can be exaggerated by cable stretch. The ring gauge or "rabbit" 


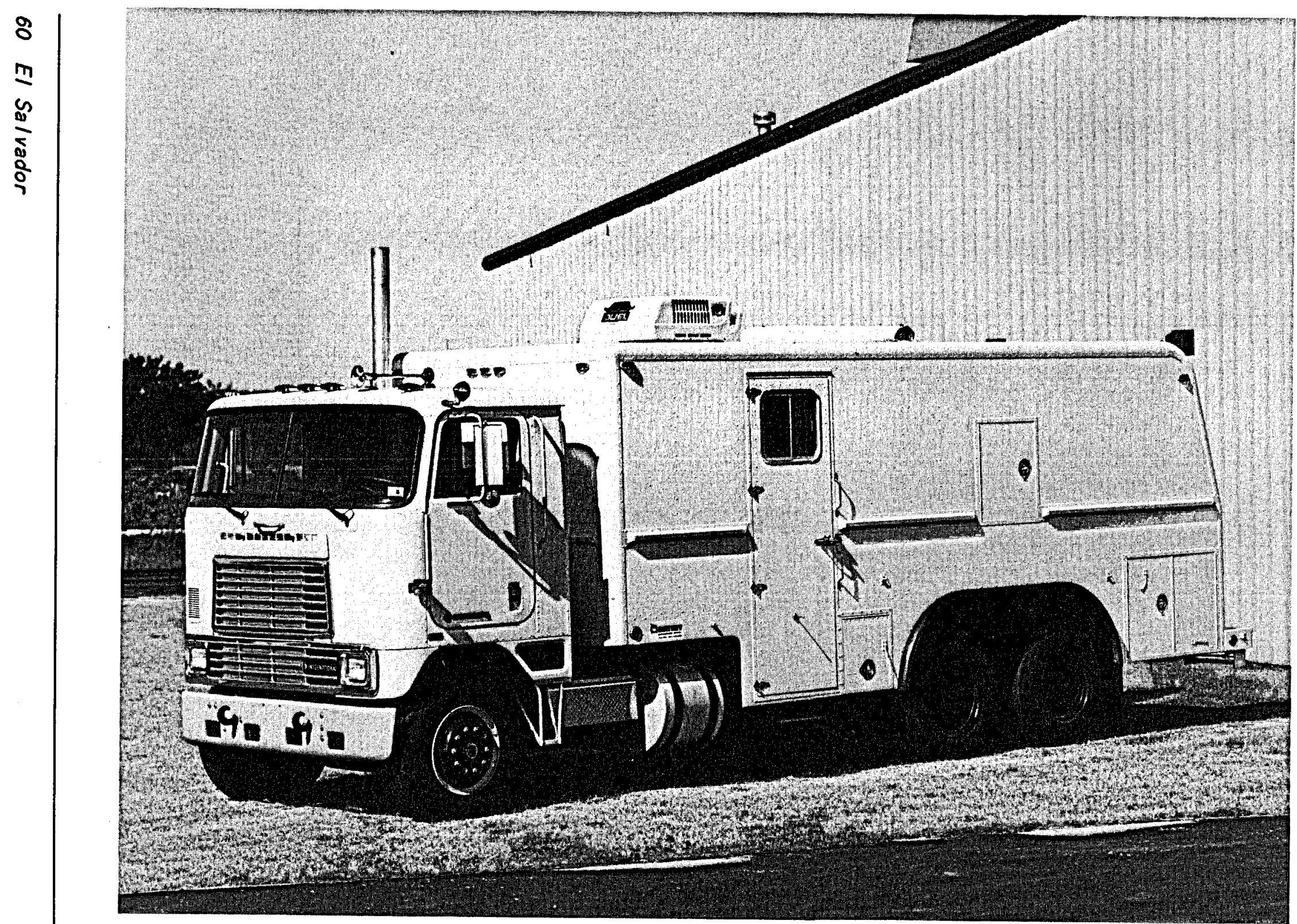

Fig. A-1. The well logging truck. 


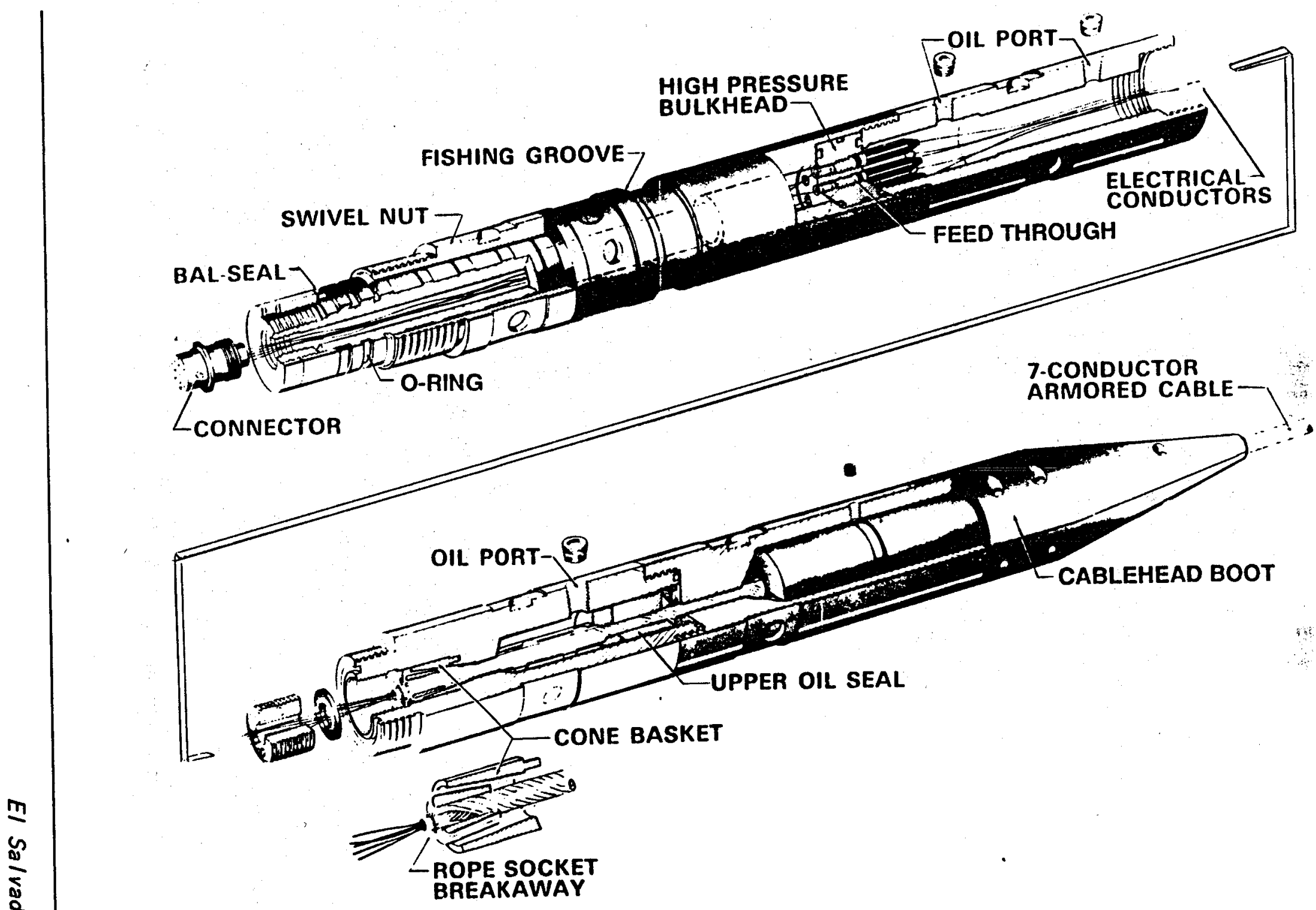

Fig. A-2. The cablehead assembly. 
is attached to the pressure housing to gauge the borehole diameter (Fig. A-3). The temperature probe with the $\mathrm{CCL}$ and rabbit is run first in every borehole before the borehole is logged with the more expensive, complex instrument packages.

The high-temperature borehole fluid sampler is operated by opening and closing a flow control valve on the 4- $\ell$ sample bottle. Once the fluid sampler is stationed at the desired depth in the wellbore, a downhole high-temperature motor is actuated to open and close the flow valves (Fig. A-4). The motor is energized upon command from the power supply in the logging truck. Before the fluid sampler is run into the borehole, a vacuum pump is used to evacuate the 4-l sample bottle. When the tool is retrieved at the surface, the sample bottle is taken to a nearby facility. where the gas and liquid fluids are preserved and prepared for further analysis.

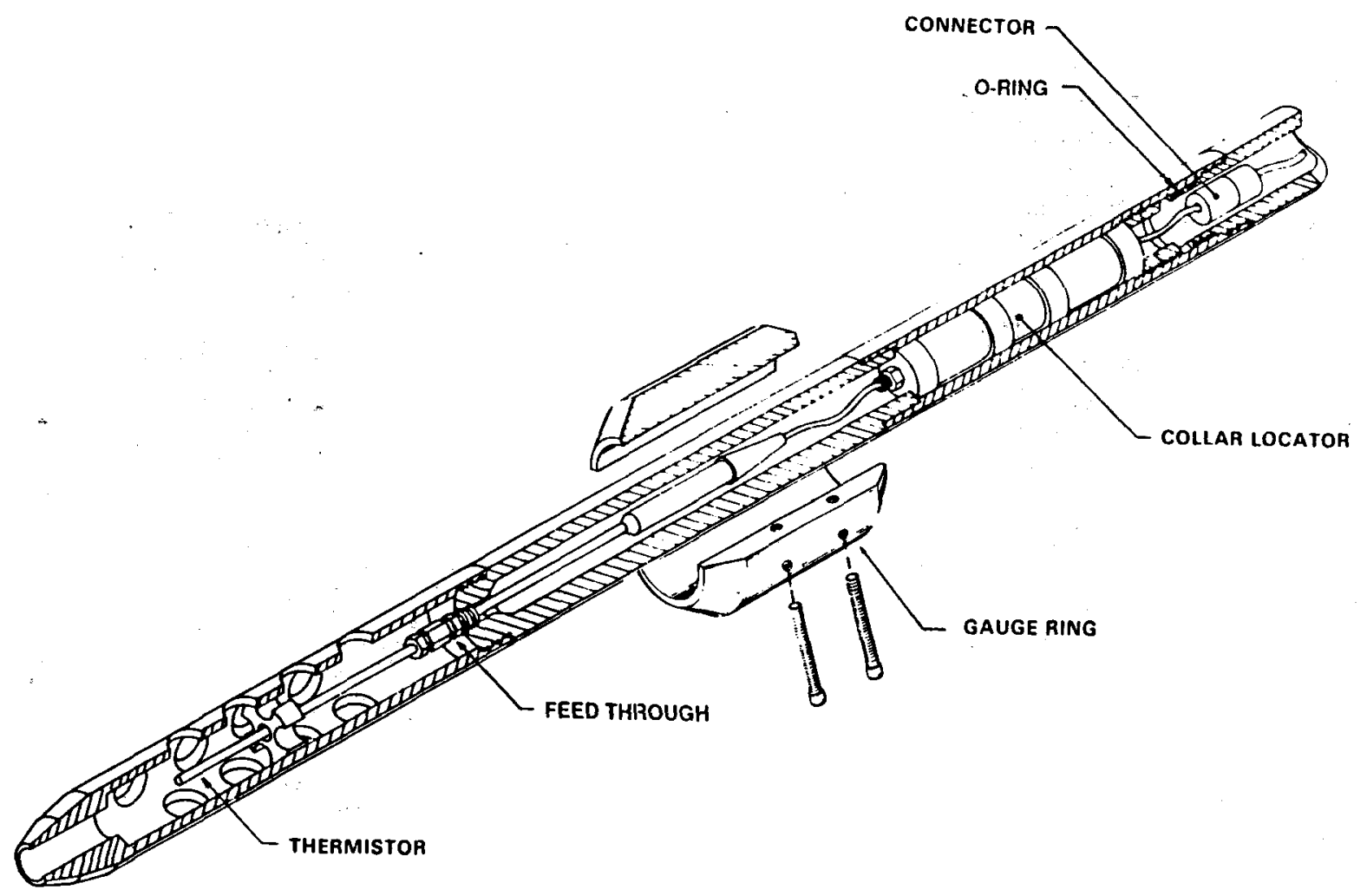

Fig. A-3. The temperature/rabbit tool. 


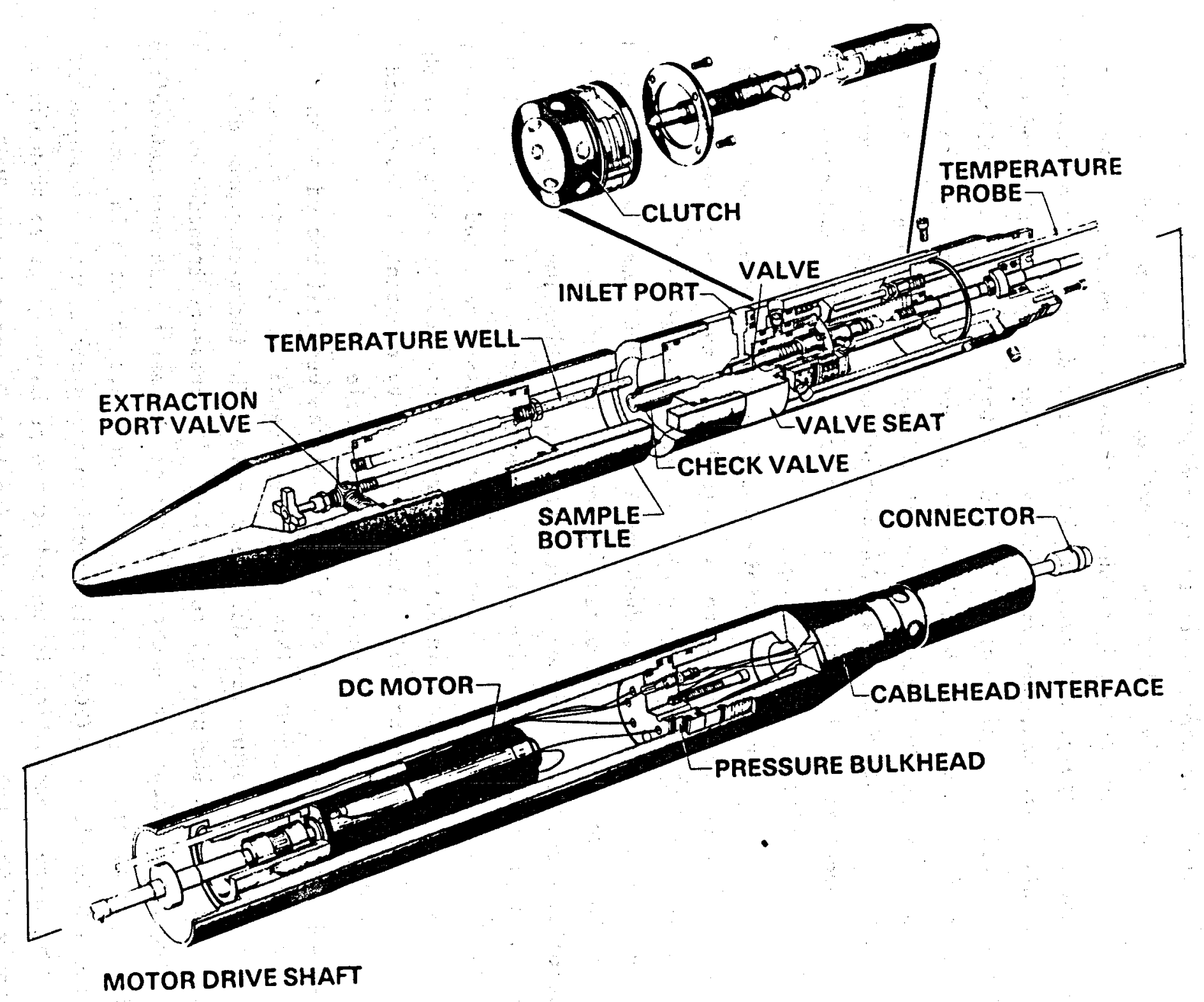

Fig. A-4. Schematic diagram of the Los Alamos in situ fluid sampler used during this investigation. 
Wellbore conditions, such as openhole or casing diameters, contour, wear, scale accumulations, breakouts, etc., can be measured using the three-arm caliper tool. The three arms, which are spaced $120^{\circ}$ apart on the circumference, operate independently. Normally the caliper tool is deployed in the wellbore, with the arms retracted, to the lowest depth of interest. The arms are then extended by applying current to the downhole dc motor and associated drive. When fully extended, the arms provide a moderate spring-activated force against the borehole or casing wall. The tool is then pulled up the wellbore, and the motion of each arm, as it follows the contour, is transformed to a rotational motion sensed by a cosine-type potentiometer. The output signal of each of the three potentiometers is a function of the radius from the center line of the centralized tool to the tip of the arm (Fig. A-5). Caliper calibration is verified before each $\log$.

To determine the thermodynamic state of a flowing wellbore, simultaneous measurements of temperature, pressure, and fluid velocity are necessary. A high-temperature $\left(300^{\circ} \mathrm{C}\right)$ well logging tool was developed specifically to measure these parameters in the production wells in Central America. This tool is referred to as the spinner/temperature/pressure or STP tool (Fig. A-6). The fluid velocity transducer (spinner) incorporates a rotating impeller with hardened steel pivot bearings. The rotation shaft operates a reed switch that transforms the rotational speed of the impeller to pulses recorded as frequency in hertz. The rotational speed in hertz is proportional to the velocity of the fluid relative to the logging tool. A proportionality constant is determined by logging in the liquid-filled region of the borehole.

The temperature sensor is a thermistor that has been calibrated to an accuracy of $0.10^{\circ}$ up to $300^{\circ} \mathrm{C}$. This temperature sensor is the same type as that used in the temperature tool described above. The thermistor provides very fast response and exceptional resolution. The pressure transducer provides accurate pressure measurement in the geothermal fluids when meticulous calibration procedures are used. Pressure measurements are made in the STP tool using a 0 to $34.5 \mathrm{MPa}$ (5000 psi) potentiometer gauge pressure transducer. The constant current excitation is sensed at the pressure gauge so that the power supply at the surface can compensate for line losses over the 3000-m armored cable. 


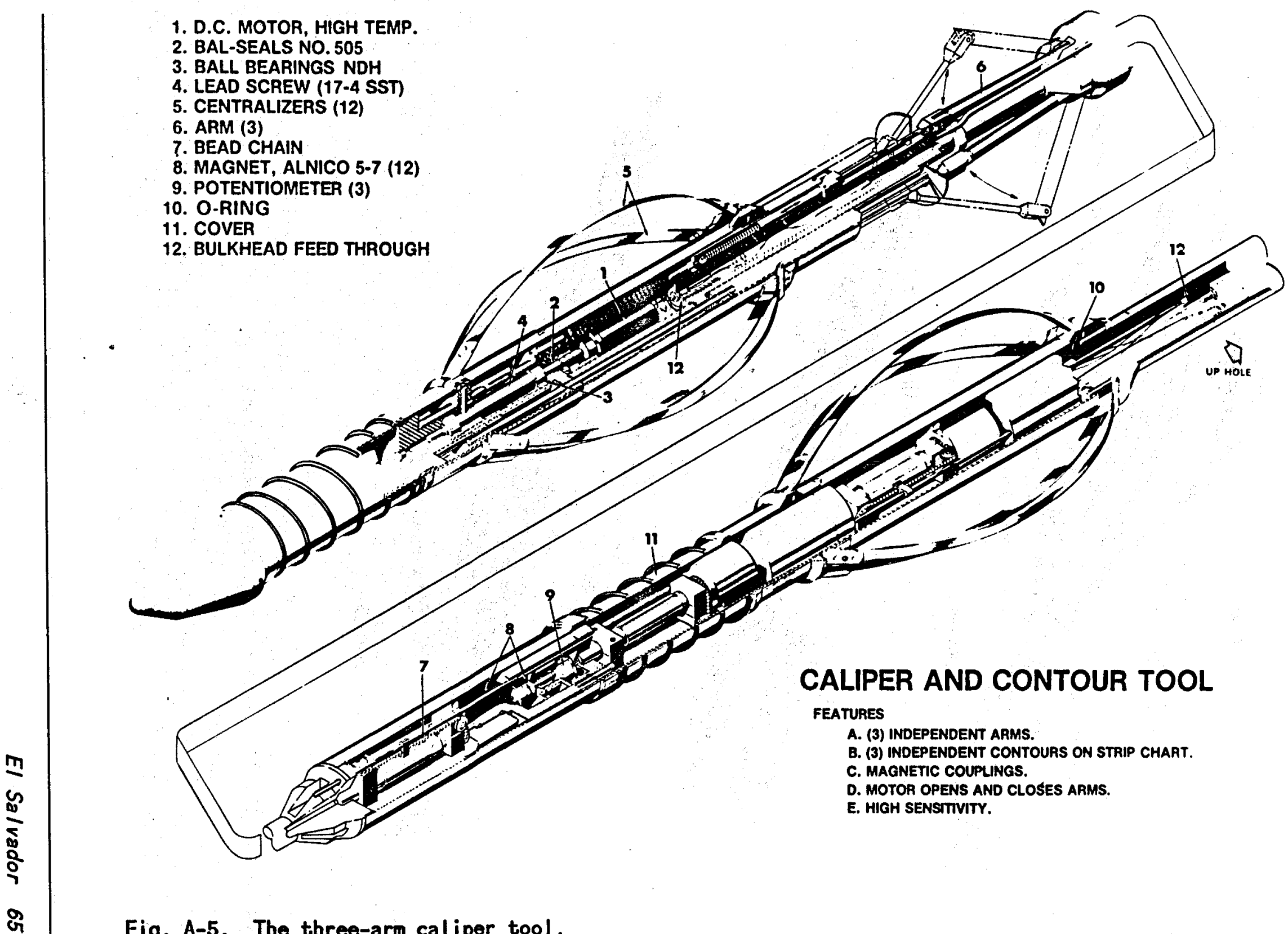

Fig. A-5. The three-arm caliper tool. 


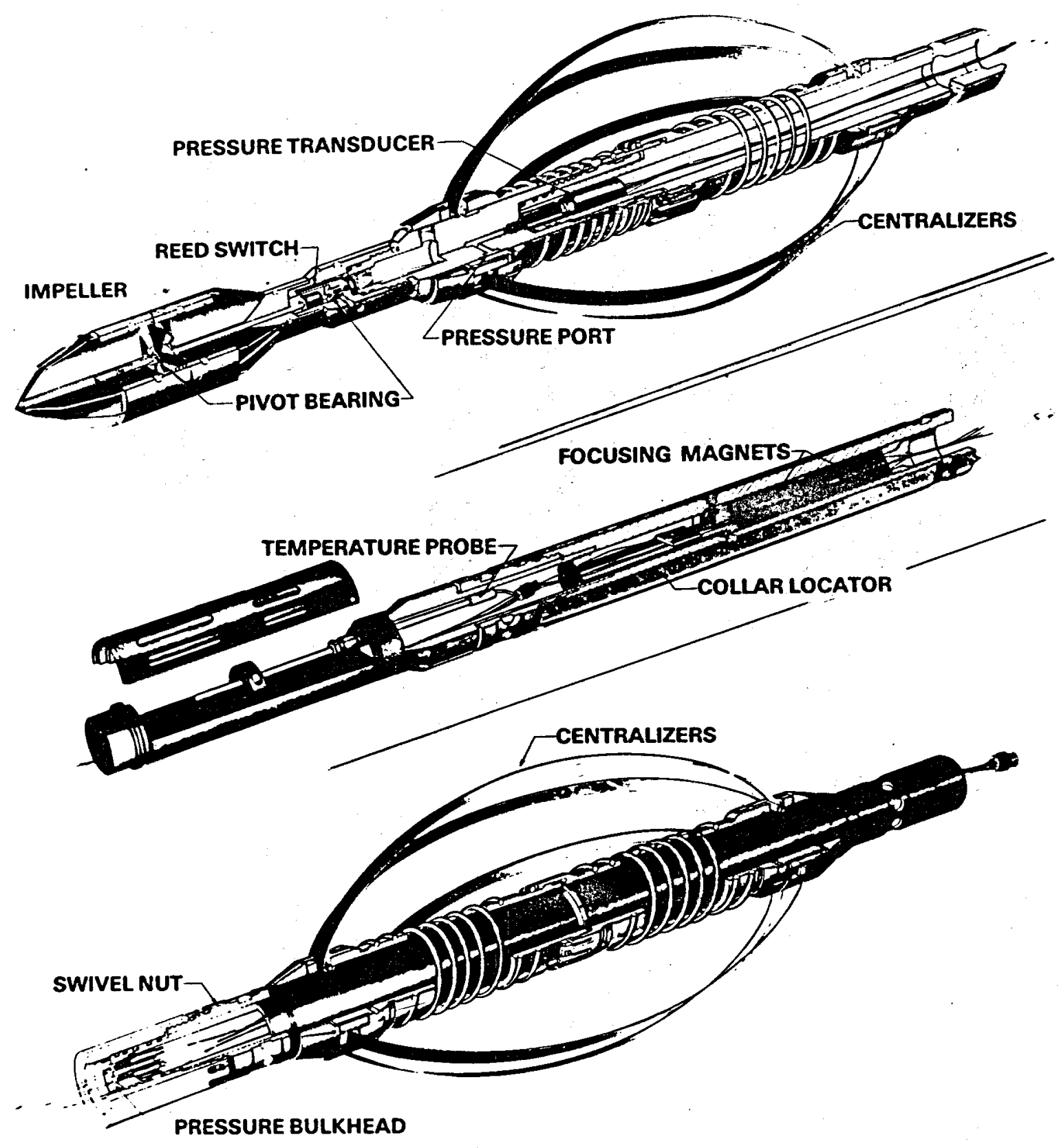

Fig. A-6. The spinner/temperature/pressure tool. 


\section{REFERENCES}

Archuleta, J., Fink, C., and Kurtenbach, J., 1978, Equipment development report: Borehole-fluid sampling tool, Los Alamos Scientific Laboratory report LA-7152-MS, 12 pp.

Dennis, B. R., Koczan, S. P., and Stephani, E. L., 1985, High-temperature borehole instrumentation, Los Alamos National Laboratory report LA-10558HDR, $46 \mathrm{pp}$.

D'Amore, F., and Panichi, C., 1980, Evolution of deep temperatures of hydrothermal systems by a new gas geothermometer, Geochim. Cosmochim. Acta, 44, pp. $549-556$.

Fouillac, C. and Michard, G., 1981, Sodium/lithium ratio in water applied to geothermometry of geothermal reservoirs, Geothermics, 10, pp. 55-70.

Fournier, R. O., 1981, Application of water geochemistry to geothermal exploration and reservoir engineering, in Rybach, L., and Muffler, L. J. P. (eds.), Geothermal Systems: Principles and Case Histories, J. Wiley, New York, Pp. 109-144.

Goff, F., Gardner, J. N., Vidale, R., and Charles, R., 1985, Geochemistry and isotopes of fluids from Sulphur Springs, Valles caldera, New Mexico, J. Volcanol. Geotherm. Res., 23, pp. 273-297.

Goff, F., Shevenell, L., Grigsby, C. O., and Dennis, B., 1987a, Downhole fluid sampling at the SSSDP California State 2-14 well, Salton Sea, California, Los Alamos National Laboratory report LA-11052-0BES, 32 pp.

Goff, F., Truesdell, A., Grigsby, C. O., Janik, C., Shevenell, L., Paredes, R., Gutiérrez, J. W., Trujillo, P., and Counce, D., 1987b, Hydrogeochemical investigation of six geothermal sites in Honduras, Central America, Los Alamos National Laboratory report LA-10785-MS, 170 pp.

Goff, F., Truesdell, A., Shevenell, L., Janik, C., Grigsby, C. O., Paredes, R., Trujillo, P., Counce, D., Gutiérrez, J. W., Adams, A., Urbani, F., and Perdimo, R., 1988, Hydrogeochemical report of the second Honduras sampling trip, January-February 1986, Unpublished Los Alamos National Laboratory • report, 105 pp.

Grigsby, C. O., Goff, F., Trujillo, P., Counce, D., Dennis, B., Kolar, J., and Corrales, R., 1989, Results of investigation at the Miravalles geothermal field, Costa Rica, Part 2: Downhole fluid sampling, Los Alamos National Laboratory report LA-11510-MS, Part 2, 45 pp.

Hoefs, J., 1973, Stable Isotope Geochemistry, Springer-Verlag, New York, $140 \mathrm{pp}$. 
Laky, C., Lipman, M. J., Bodvarsson, G. S., Retana, M., and Cuel lar, G., 1989, Hydrologic model of the Ahuachapan geothermal field, El Salvador, Stanford Geothermal Workshop 1989, Stanford, California, 8 pp.

Norman, D. I., and Bernhardt, C. A., 1981, Assessment of geothermal reservoirs by analysis of gases in thermal waters, Final Report, New Mexico Energy Institute, New Mexico State University, Las Cruces, 130 Pp.

Pearson, F. J., and Truesdel I, A. H., 1978, Tritium in the waters of Yellowstone National Park, US Geol. Surv. Open-File Rpt;.; 78-701, 4 pp.

Steingrimsson, B., Bodvarsson, G. S., Cuellar, G., and Escobar, C., 1989, Changes in thermodynamic conditions of the Ahuachapan reservoir due to production and injection, Stanford Geothermal Workshop 1989, Stanford, California, 14 pp.

Truesdell, A. H., Aunzo, Z., Bodvarsson, G., Alonso, J., and Campos, A., 1989, The use of Ahuachapán fluid chemistry to indicate natural state conditions and reservoir processes during exploitation, Stanford Geothermal Workshop 1989, Stanford, California, 7 pp.

Trujillo, P., Counce, D., Grigsby, C. O., Goff, F., and Shevenell, L., 1987, Chemical analysis and sampling techniques for geothermal fluids and gases at the Fenton Hill laboratory, Los Alamos National Laboratory report LA11006-MS, 84 pp. 